OECD Economics Department Working Papers No. 1090

\title{
Vincent Koen,
}

Policies for Inclusive Richard Herd,

Urbanisation in China

\section{Thomas Chalaux}




\section{Unclassified}

ECO/WKP(2013)82

Organisation de Coopération et de Développement Économiques

Organisation for Economic Co-operation and Development

10-Oct-2013

ECONOMICS DEPARTMENT

English - Or. English

POLICIES FOR INCLUSIVE URBANISATION IN CHINA

ECONOMICS DEPARTMENT WORKING PAPER No. 1090

By Vincent Koen, Richard Herd, Xiao Wang and Thomas Chalaux

All Economics Department Working Papers are available through OECD's Internet website at www.oecd.org/eco/Workingpapers

JT03346109

Complete document available on OLIS in its original format

This document and any map included herein are without prejudice to the status of or sovereignty over any territory, to the delimitation of international frontiers and boundaries and to the name of any territory, city or area. 


\section{Abstract/Résumé \\ Policies for inclusive urbanisation in China}

Urbanisation in China has long been held back by various restrictions on land and internal migration but has taken off since the 1990s, as these impediments started to be gradually relaxed. People have moved in large numbers to richer cities, where productivity is higher and has increased further thanks to agglomeration effects. In the process, the rural-urban income differential has narrowed. Urbanisation also entails costs, however, notably in the form of congestion, all the more so as public transport provision has not kept up. Demand for living space is set to continue to increase as living standards improve, putting pressure on land prices. This can be offset by relaxing the very stringent restrictions on the use of agricultural land for building. For migrants to better integrate in the cities where they work, their access and that of their families to education, health and other social services must continue to improve, in particular via further changes to the registration system, coupled with more market-based rules on land ownership and use.

This Working Paper relates to the 2013 OECD Economic Survey of China (www.oecd.org/eco/surveys/china).

JEL classification: D63, H23, H41, H51, H52, H53, H54, H55, H77, I39, J11, J21, J61, K11, K39, N35, O18, O53, P21, P25, P26, P27, P28, Q15, Q18, Q53, R11, R12, R14, R21, R23, R28, R31, R38, R41, R48, R52, R58.

Keywords: agglomeration effects, agriculture, China, cities, congestion, housing, hukou, land, migration, pollution, public transport, scale economies, social services, urbanisation, urban-rural divide.

\section{Comment favoriser une urbanisation plus inclusive en Chine}

Alors que l'urbanisation était depuis longtemps freinée en Chine par diverses restrictions appliquées au marché foncier et aux migrations internes, elle s'intensifie depuis que ces obstacles ont commencé à être progressivement levés dans les années 90 . Les villes plus riches, caractérisées par une productivité élevée et en constante progression du fait des économies d'échelle générées par l'urbanisation, enregistrent un afflux massif de migrants. Parallèlement, l'écart de revenus entre zones rurales et urbaines s'est resserré. Néanmoins, l'urbanisation a aussi un coût, notamment illustré par les problèmes de congestion, aggravés par le développement insuffisant de l'offre de transports publics. La demande de surface habitable devrait rester orientée à la hausse sous l'effet de l'amélioration du niveau de vie, ce qui exercera une pression sur les prix des terrains. Cette pression peut être atténuée en assouplissant les restrictions très sévères appliquées à l'usage des terres agricoles à des fins de construction. Pour veiller à une meilleure intégration des migrants dans les villes où ils travaillent, il faut continuer à améliorer leur accès et celui de leurs familles à l'éducation, aux soins de santé et aux autres types de services sociaux, notamment en poursuivant la réforme du système d'enregistrement et en adoptant une réglementation plus axée sur le marché en ce qui concerne la propriété et l'utilisation des terres.

Ce Document de travail a trait à l'Étude économique de l'OCDE de la Chine, 2013 (www.oecd.org/eco/etudes/chine). Classification JEL : D63, H23, H41, H51, H52, H53, H54, H55, H77, I39, J11, J21, J61, K11, K39, N35, O18, O53, P21, P25, P26, P27, P28, Q15, Q18, Q53, R11, R12, R14, R21, R23, R28, R31, R38, R41, R48, R52, R58.

Mots clés: agriculture, Chine, clivage urbain-rural, congestion, économies d'échelle, effets d'agglomération, hukou, logement, migration, pollution, terres, transports publics, services sociaux, urbanisation, villes. 


\section{TABLE OF CONTENTS}

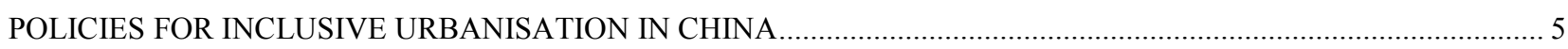



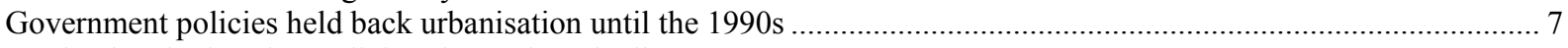

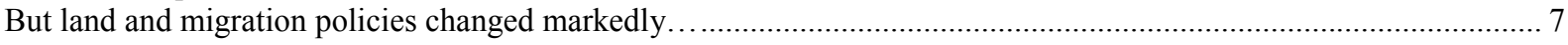

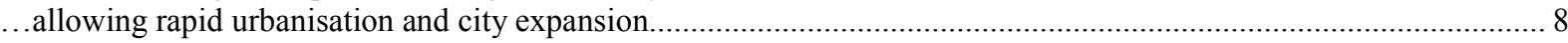

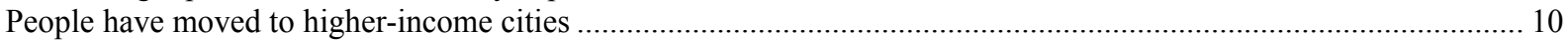

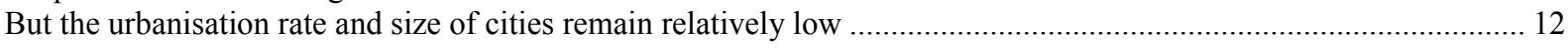

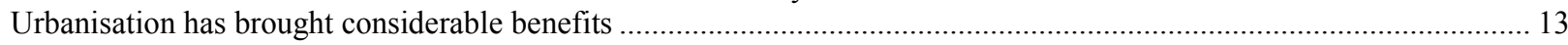

Productivity and living standards are higher in large metropolitan areas .......................................................... 13

Compact cities are energy efficient but industrial parks have proliferated ....................................................... 15

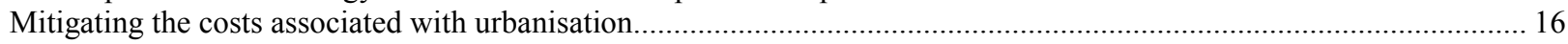

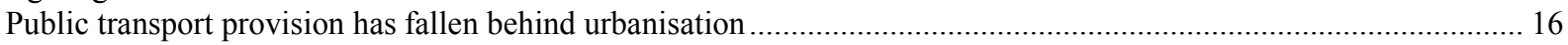

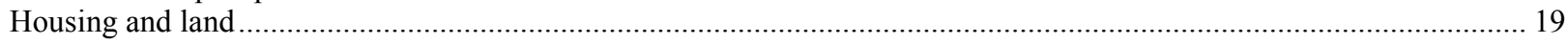

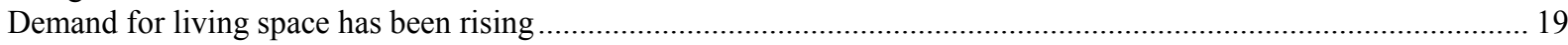

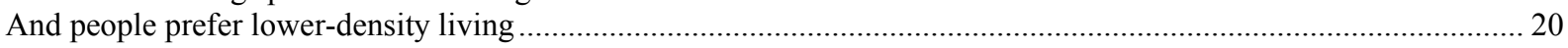

Population growth has added to the demand for extra housing ....................................................................... 21

Urbanisation and the demand for more space has pushed up housing investment ...................................................22

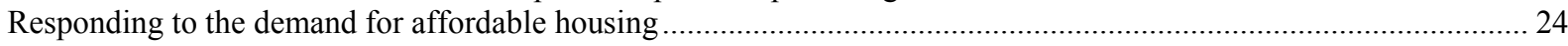

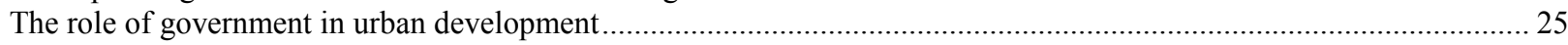

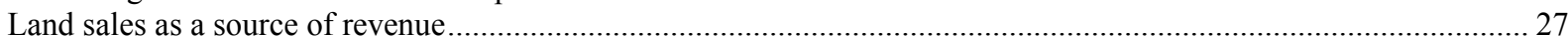



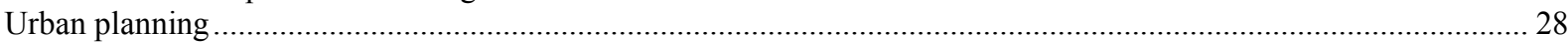

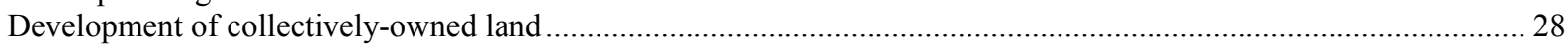

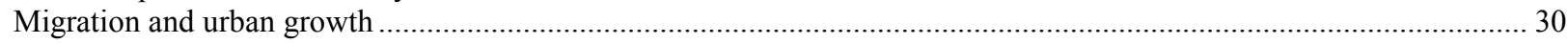



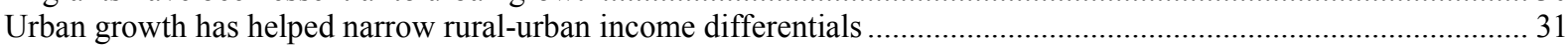

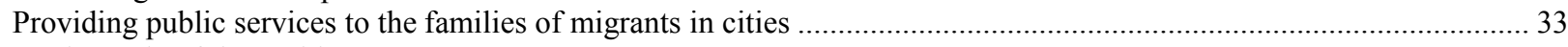



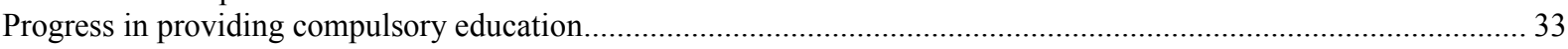

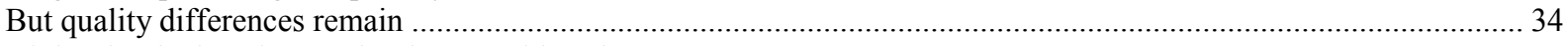

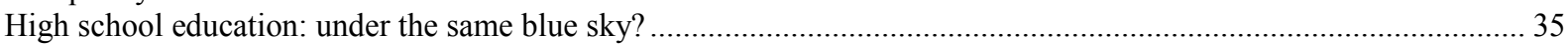

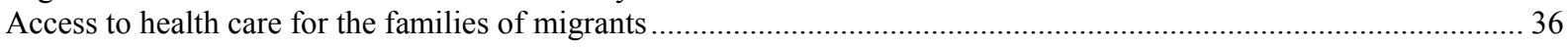

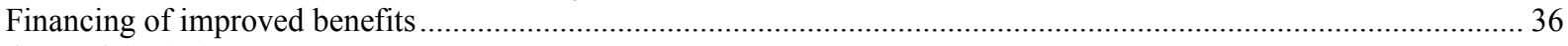

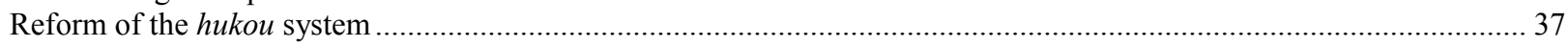

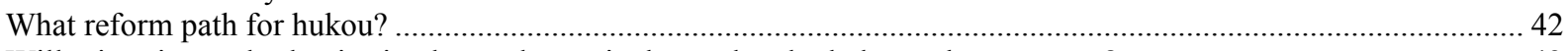

Will migration and urbanisation boost domestic demand and rebalance the economy? ..................................... 42

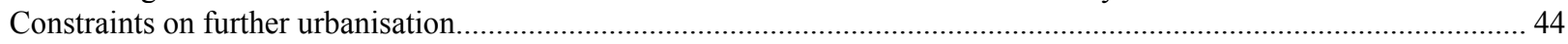

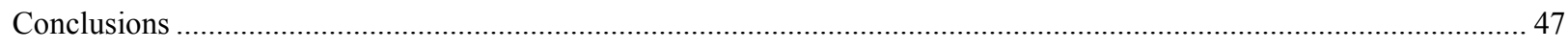

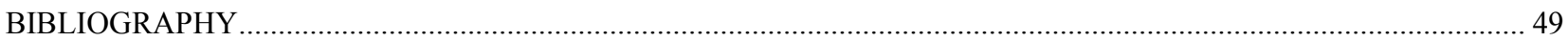

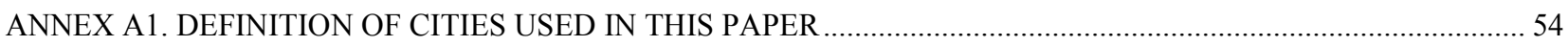



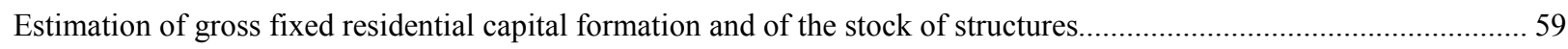

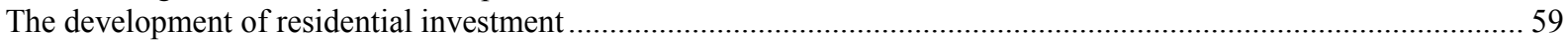



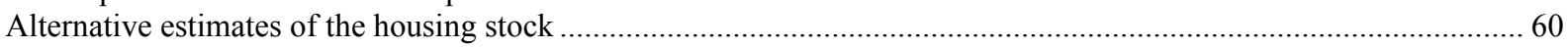

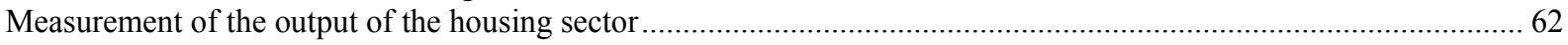

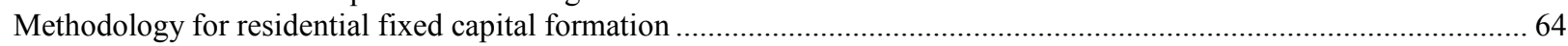

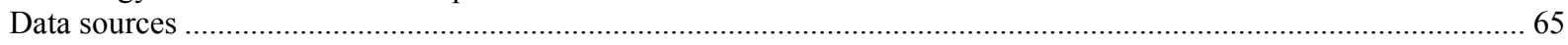

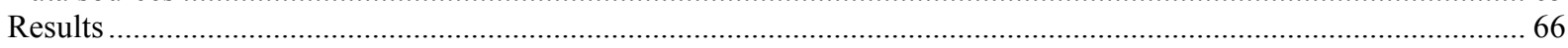

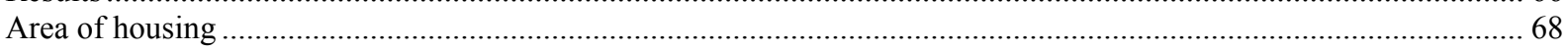



Tables

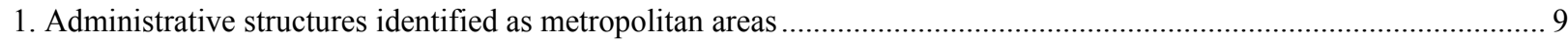

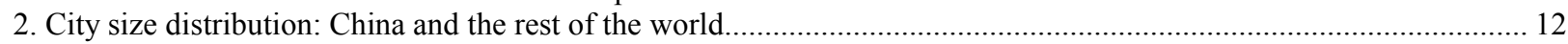



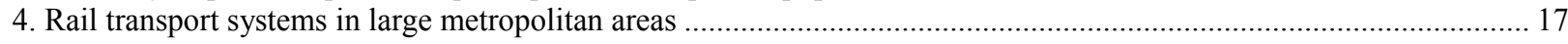




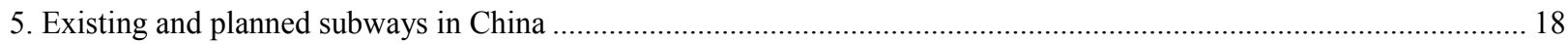

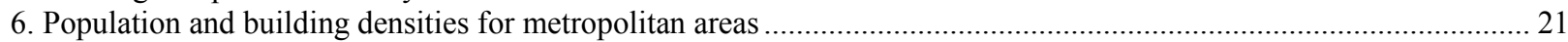

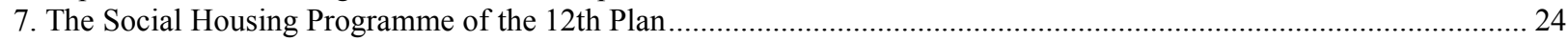



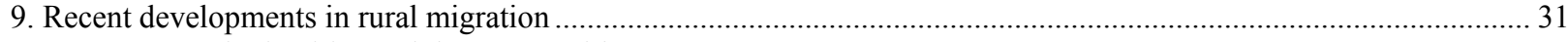

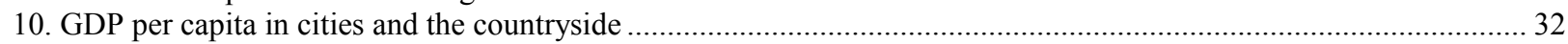

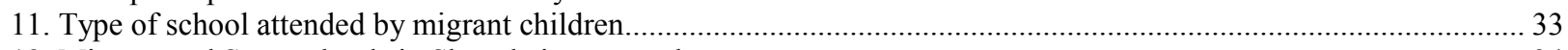

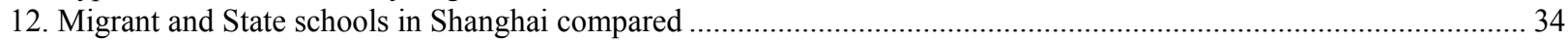

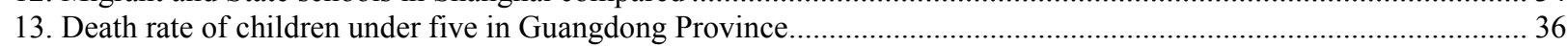

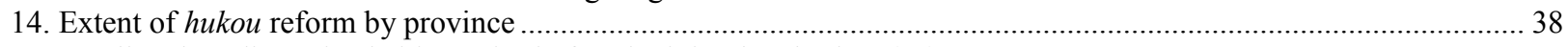

15. Small and medium-sized cities: criteria for obtaining local urban hukou ....................................................... 39

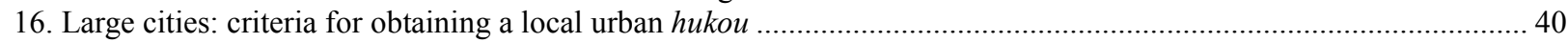

17. The point system for acquiring an urban hukou in Guangdong .................................................................. 41

18. National security and food security: the example of Britain during the Second World War ................................... 46

A1.1. Chinese metropolitan areas grouped by tiers: selected socio-economic data ................................................ 55

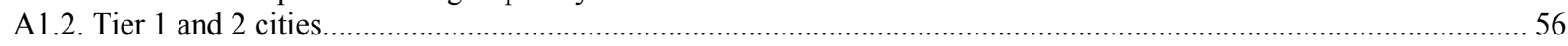

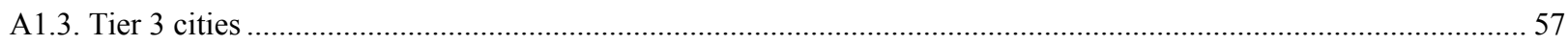

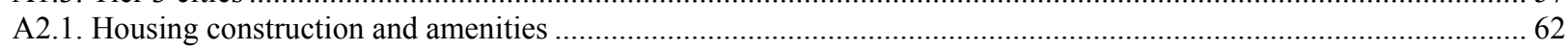

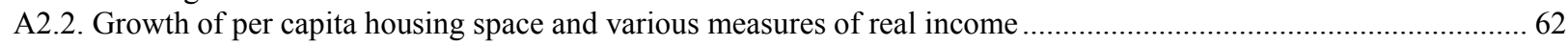



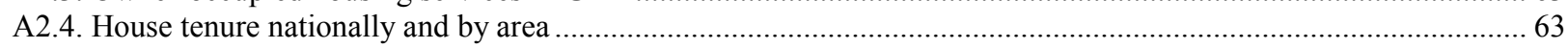

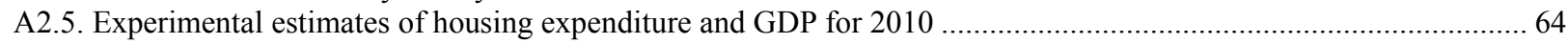

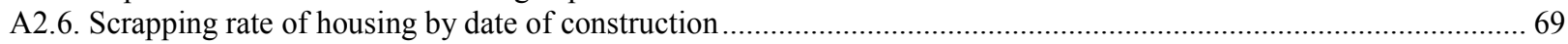

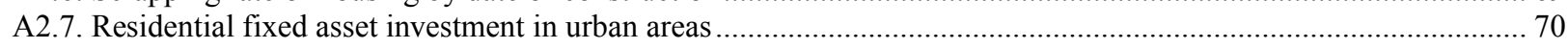

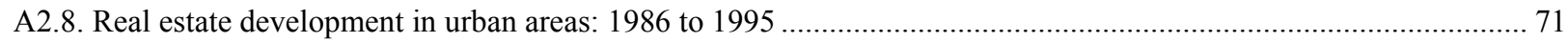

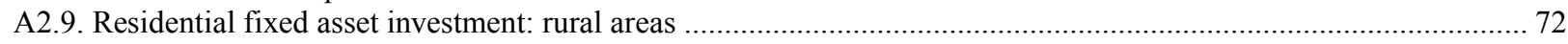





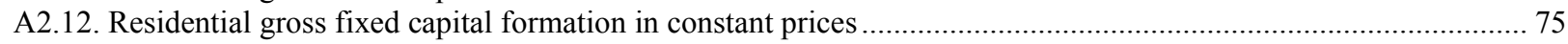



A2.14. Residential fixed asset investment: reconciliation with sales data .......................................................... 77

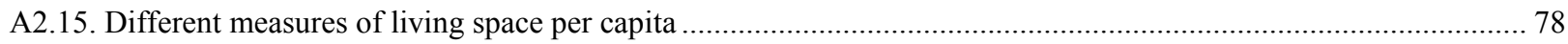

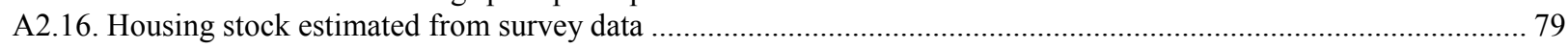

A2.17. Stock of housing estimated from flow of newly completed houses ......................................................... 80



Figures

1. The largest 500 Chinese metropolitan areas by GDP per capita: international comparison ...................................... 5

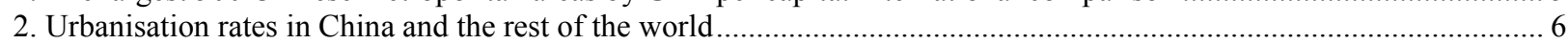

3. GDP per capita in Chinese cities and lower-income OECD member and accession countries in 2012 ...................... 10

4. Metropolitan areas: annual population growth and initial size …................................................................ 11

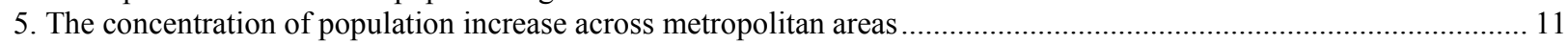

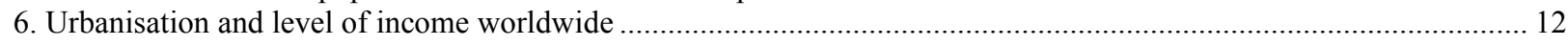



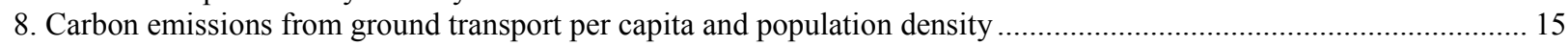



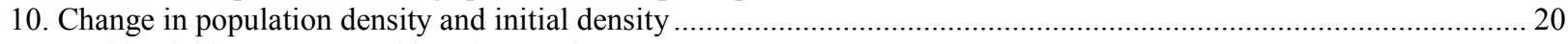

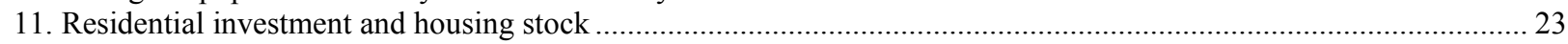



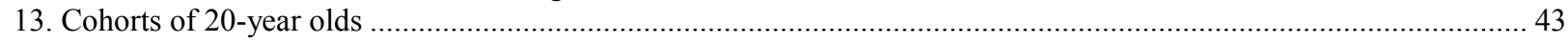

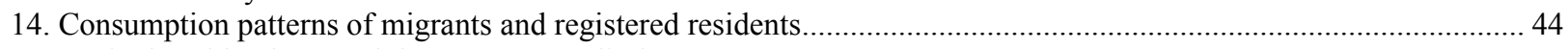

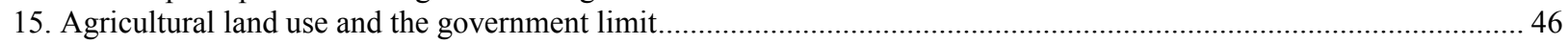

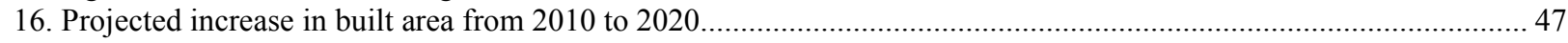

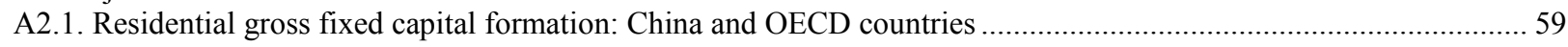

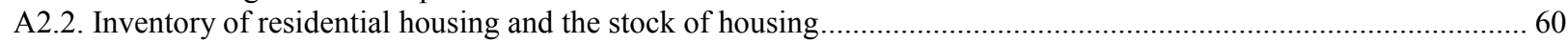

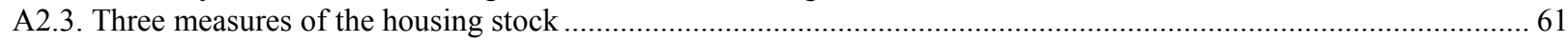

Boxes

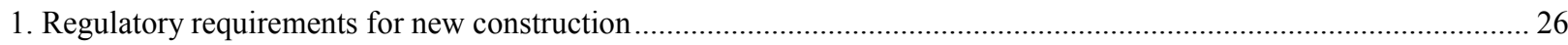

2. The urban-rural income differential in China appears to be overstated …........................................................ 32

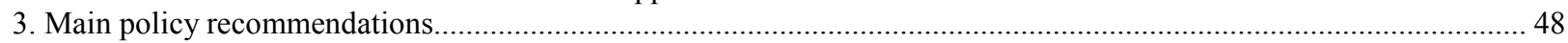




\title{
POLICIES FOR INCLUSIVE URBANISATION IN CHINA
}

\author{
Richard Herd, Thomas Chalaux, Vincent Koen and Xiao Wang ${ }^{1}$
}

Urbanisation has come a long way in China over the past two decades. Over half of the population is now officially classified as urban. By 2010, just under one-quarter of the Chinese population, amounting to 310 million people, lived in metropolitan areas with income per head matching that in the three lowestincome OECD countries: Chile, Mexico and Turkey (Figure 1). After a historical overview of the urbanisation process, this chapter discusses the associated benefits and costs (the environmental challenges stemming from the rapid expansion of cities are also discussed in Hill, 2013). It then examines the drivers of urbanisation - notably rural-urban migration - and the role played by government in the process. Going forward, both land rights and migrants' access to public services in cities are key for inclusive urbanisation.

Figure 1. The largest 500 Chinese metropolitan areas by GDP per capita: international comparison

GDP per capita by groups of 25 metropolitan areas in 2010, using the PPP exchange rate of the World Bank

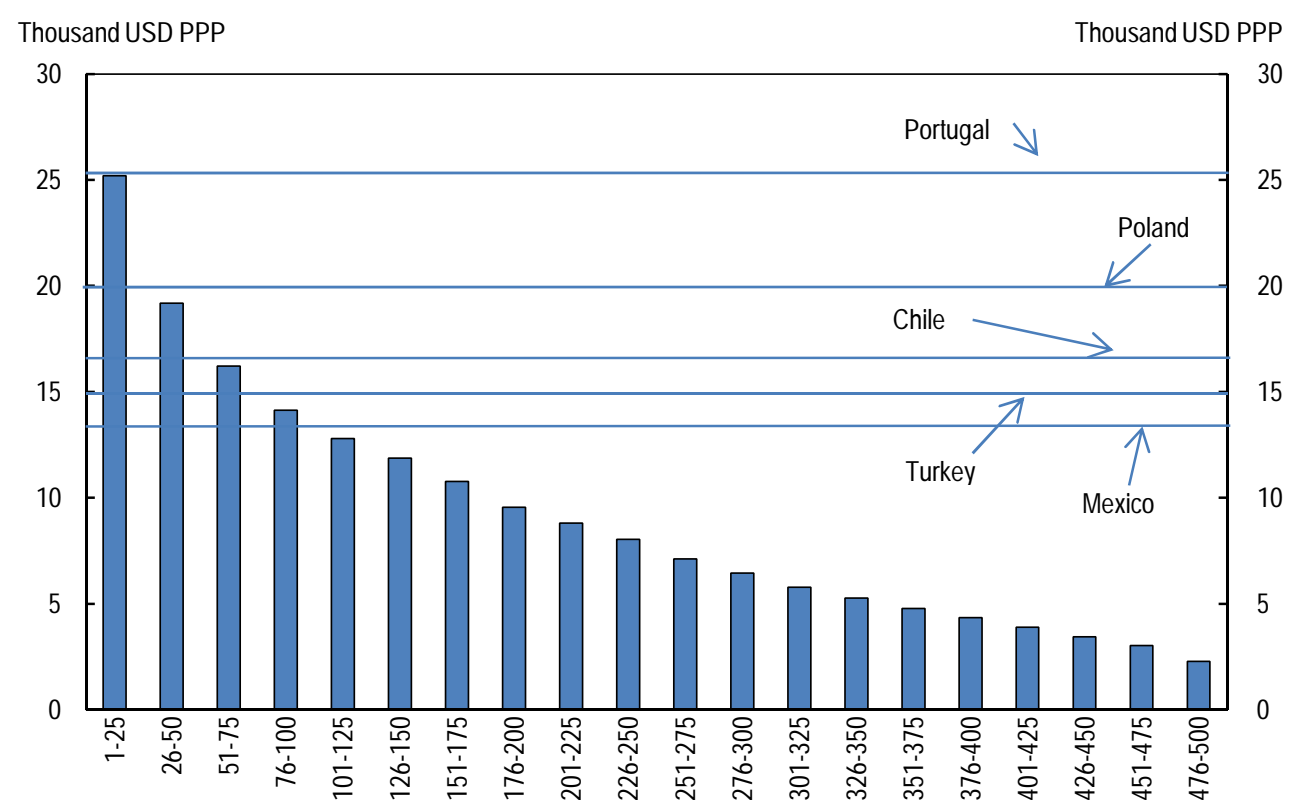

Source: CEIC, National Bureau of Statistics: City Statistical Yearbook; Communiqués on $10^{\text {th }}$ Census issued by local national Bureau of Statistics offices; World Development Indicators. The methodology for selecting and defining metropolitan areas is explained below.

1. Richard Herd heads the China desk and Vincent Koen is Division Chief in the OECD Economics Department. Thomas Chalaux was a research assistant and Xiao Wang a consultant on the China desk at the time of writing. This paper was originally produced for the 2013 OECD Economic Survey of China published in March 2013. The authors thank Andrew Dean, Robert Ford, Sam Hill and Cristina Martinez as well as officials from the Chinese government for valuable comments on earlier drafts, and Nadine Dufour for editorial assistance. 


\section{Urbanisation in China: a long history}

The first cities in China appear to have emerged after those in Mesopotamia, Egypt and India, probably because irrigation came later in China. By 1400BC the first major city of China (Anyang) developed with an area of around $3 \mathrm{~km}^{2}$, substantially less than Babylon's. In contrast to Western cities, China's were part of a structured network of walled cities that controlled the neighbouring countryside (Trewartha, 1952). Chinese cities continued to grow under the Chou dynasty, with Chang'an (Xi'an) reaching a population of 146000 by 195BC. They more than doubled in size in the next two centuries.

Under the Chi' in and Han dynasties, cities prospered and a two-level administrative structure was put in place with 36 provinces and 320 prefectures. After being destroyed, the city of Chang' an was rebuilt and became one of the largest cities in the world, along Babylon and Baghdad, with a population of over one million by around $700-$ a size only reached by London in 1801 and Paris in 1850 . Under the Ming and Qing dynasties, there were 13 cities with over 500000 inhabitants (Chang, 1963). As a result, China's share of the world's overall urban population far exceeded its share of the total population up to the beginning of the industrial revolution in Europe (Figure 2). Even so, China largely remained a rural society with towns fulfilling a predominantly administrative and trading function. The urbanisation rate peaked around 1600 and then slowly declined as the country remained inwardly-oriented economically and suffered from invasions. By the early 1900s, the urbanisation rate was barely above the rate achieved four centuries earlier.

Figure 2. Urbanisation rates in China and the rest of the world



Source: Goldewijk et al. (2010).

Urbanisation progressed slowly during the following 50 years. A number of major coastal cities emerged as foreign trade grew through the enforced opening of a number of cities with foreign concessions. Towns such as Shanghai, Tianjin and Guangzhou grew to over a million inhabitants. This process was interrupted by war and revolution, so that by 1949 , at $12 \%$, the urbanisation rate in China was only around one-third that in the rest of the world. 


\section{Government policies held back urbanisation until the 1990 s}

In the early years of the new China that emerged in the late 1940s, rehabilitation, the first five-year plans and the initial period of the Great Leap Forward brought the urbanisation rate up to close to $20 \%$ by 1960. However, the agricultural sector was unable to respond efficiently to the outflow of labour as it was still organised on a collective basis and grain supply fell. The government sent people back to the countryside to boost food production and by 1963 the urbanisation rate had dropped to $17 \%$.

Government policies during this period left a long-standing mark on urban planning in China. The famines of the early 1960s reinforced the idea that national security requires a stable source of domestically-produced food, especially grains. An extremely restrictive household registration system (hukou) limited household mobility until the late 1980s.

The economic opening-up that started in 1978 saw a marked acceleration in urbanisation. Restrictions on population mobility were eased and many people were allowed to return to urban areas. In 1984, people with an agricultural hukou were allowed to move to cities as long as they could provide themselves with food and lodging. In addition, in small towns and county cities, pilot programmes were introduced to reduce differences between urban and rural hukou holders. Finally, a new temporary residence permit was introduced for people who moved outside their registered location. The entrepreneurial spirit generated by the liberalisation of farming helped create a large number of small enterprises drawing local people into towns and smaller cities, which were also favoured by the policy of industrialisation without urbanisation. The overall result was that during the 1980s and 1990s smaller cities grew faster than large cities (Fan, 1999; Anderson and Ge, 2005).

The faster development of smaller cities was in fact an explicit policy objective. In 1979, the Chinese Communist Party decided that the country should develop its small towns and gradually equip them with modern industry so that they could transform the countryside. The growth of large cities was to be constrained by building satellite cities around them. Twenty years later this policy was still in place, with the Communist Party stating that the government should avoid the "blind" flow of labour to large and even medium-sized cities, and calling for measures to promote the development of small towns.

The fast development of small cities came in a period when the price of land was effectively set to zero. All land in the administrative area of urban district governments belonged to the state. Urban land was given to state-owned enterprises (SOEs) which developed in accordance with the priorities of the government bureaux which managed them. This led to an irrational use of land in cities. For example, in 1990 in Shanghai over one-quarter of land in the central districts was under industrial use, which included housing for the workers in those firms. Experiments in selling land-use rights started in Shanghai and Shenzhen during the 1980s but it was not until 1990 that the State Council disseminated the Provisional Regulations on the Granting and Transferring of Land-Use Rights for State-Owned Land in Cities and Towns. This document introduced the concept of time-limited land-use rights (similar to land leases) that were transferable but did not confer ownership of the land itself. The law was implemented at the local level and most projects involved commercial developments.

\section{But land and migration policies changed markedly...}

While the legal framework had changed, progress in introducing a market in land was limited during the 1990s. Most local governments saw land as a means of housing new industrial enterprises. New development meant higher tax revenues, part of which could be kept by the local government. This resulted in competition between areas which meant that most land for industrial use was assigned without any payment. The transformation of the land market only occurred once the housing market had been reformed. 
Reform of the housing market took over a decade. A 1988 government document called for privatisation of housing, but few SOEs responded and this stymied the reform as most urban workers were housed by their employer at the time. In 1994, a State Council Decision on Deepening Housing Reform created two types of new housing construction: economic housing and commodity housing, with the former being reserved for low and middle-income families. At the same time a housing saving system was introduced. The reform did not deliver the desired results (Deng et al., 2009): development companies started but most new housing was sold to SOEs that in turn sold the flats to employees at a large discount.

The nature of the urbanisation process changed in 1998, however, when the State Council issued its Decision on Further Deepening Reform of the Urban Housing System and Accelerating Housing Construction. This document broke the link between the enterprise and housing for its employees. SOEs were forbidden to buy new housing and had to sell their existing stock to the occupants, opening the way for commercial development of housing that responded to market requirements.

While the above reforms set the scene for market-oriented development, the Land Administration Act that came into effect in 1999 has constrained the urbanisation process. It provides that land should be split into three categories: i) basic agricultural land, which cannot be rezoned into building land without permission from the State Council; ii) remaining agricultural land ( $20 \%$ of total agricultural land), which can be rezoned only if other land is brought under cultivation, and subject to permission from the State Council if the rezoning covers more than 35 hectares; iii) land which was designated for development prior to the passage of the law.

Migration laws and regulations were liberalised after land and housing markets. As noted above, in the 1990s, the policy focus was still on preventing the rural labour force from moving to large cities, to wit the notice from the State Council and other Ministries on Further Improving the Control of the Outflow of Migrant Workers. Only in 2002 did policy start to change with measures to cancel fees for migrant workers and improve training.

\section{...allowing rapid urbanisation and city expansion}

Between 1978 and 2011, the urban population has grown by a factor of four. Before the late 1970s, the urban population was growing by less than 5 million people per year. By the decade that ended in 2010, it was expanding by 20 million per year. As a result the proportion of people living in urban areas rose from $17 \%$ to $51 \%$ between 1978 and 2011 .

Not all people who live in urban areas live in cities (see Annex A1), yet cities rather than urbanisation are key to growth. Cities provide large labour markets where specialist occupations can thrive, facilitate the exchange of information and allow to cluster activities. In addition, cities offer diverse cultural and entertainment possibilities that are only viable in large economic catchment areas. For this reason, the development of cities seems more important than urbanisation itself. A dispersed set of villages each with a population density of more than a set level might be considered as urban but would not constitute a city where agglomeration economies can be reaped.

In China, the word city is used to describe an administrative area that might not, outside of China, be seen as city. A city can cover an area that is physically huge and contains both a large urban core and a vast rural hinterland (e.g. Chongqing). Within that hinterland, there can be areas that are also known as cities but which differ little from neighbouring areas which are not called cities. By the administrative definition there are over 600 cities in China, ranging in status from directly-controlled municipalities to provincial capitals with a direct link to the central government, prefectural-level cities and finally relatively small county cities. This classification takes little account of urbanisation factors but generates a hierarchy of areas, each with less administrative power. In order to exclude areas that are actually more rural than 
urban, the new analysis presented below rests on the notion of metropolitan areas, identified using two criteria: an overall population greater than 300000 and a population density exceeding 500 people per square kilometre at the lowest administrative level, which is that of a county. On this basis, there were 515 metropolitan areas in 2010 (Table 1). These generate the bulk of valued-added in China: indeed, just 200 of them accounted for slightly over half of GDP in 2010. The population data for 100 of the metropolitan areas, defined as above, are given in Annex A1.

Table 1. Administrative structures identified as metropolitan areas ${ }^{1}$

\begin{tabular}{|c|c|c|c|c|c|c|c|}
\hline \multirow[b]{2}{*}{ Type } & 2000 & 2010 & 2000 & 2010 & \multicolumn{3}{|c|}{2010} \\
\hline & \multicolumn{2}{|c|}{ Number } & \multicolumn{2}{|c|}{$\begin{array}{l}\text { Population } \\
\text { (millions) }\end{array}$} & $\begin{array}{c}\% \text { of } \\
\text { national } \\
\text { population }\end{array}$ & $\begin{array}{c}\% \text { of } \\
\text { national } \\
\text { GDP }\end{array}$ & $\begin{array}{c}\text { Density } \\
\text { (people per } \\
\mathrm{km}^{2} \text { ) }\end{array}$ \\
\hline $\begin{array}{l}\text { Directly-controlled municipalities }{ }^{2} \\
\text { Specially desianated cities and }\end{array}$ & 4 & 4 & 39.0 & 58.6 & 4.4 & 10.7 & 2317 \\
\hline provincial capitals & 25 & 26 & 74.2 & 102.8 & 7.7 & 16.0 & 2222 \\
\hline $\begin{array}{l}\text { Specially designated cities which are } \\
\text { not provincial capitals }\end{array}$ & 5 & 5 & 16.8 & 22.5 & 1.7 & 5.3 & 2421 \\
\hline Prefectural cities & 143 & 157 & 151.8 & 180.9 & 13.5 & 20.7 & 1205 \\
\hline County cities & 111 & 112 & 92.2 & 99.1 & 7.4 & 11.0 & 762 \\
\hline Counties & 226 & 211 & 170.0 & 149.7 & 11.2 & 7.6 & 656 \\
\hline Total & 514 & 515 & 543.9 & 613.5 & 45.8 & 71.2 & 1041 \\
\hline
\end{tabular}

1 The definition of a metropolitan area excludes the population of those urban districts which had a population density of less than 500 people per $\mathrm{km}^{2}$ in 2010.

2. In the Chongqing Municipality, only the population of the urban districts of Chongqing city has been included.

Source: OECD calculations.

There are no precise rules that determine the place of a city in the administrative hierarchy and so often cities in China are referred to as belonging to a certain tier. While there is usually agreement about the areas in Tier 1 (Beijing, Guangzhou, Shanghai, Shenzhen and Tianjin), there is often no agreement about the cities in Tier 2 or Tier 3 and lower. Here, cities have been ranked on the basis of the average of their population and GDP ranks. The 25 cities following the Tier 1 cities are designated Tier 2, while the next 70 become Tier 3 cities. The ranking of the cities, their population, population growth and GDP in 2010 are shown in Annex 1, together with a summary table for the averages for Tier 1 to 5 cities.

Estimates updated to 2012 show that the average PPP GDP per capita (using a nationwide PPP exchange rate) of Tier 1 cities is close to that of several Central European OECD members (Figure 3), while Tier 2 and Tier 3 cities had GDP per capita similar to those in Chile, Mexico, Turkey but well above the latest Latin American countries in accession talks to join the OECD. 
Figure 3. GDP per capita in Chinese cities and lower-income OECD member and accession countries in 2012



Source: OECD EO93 Database, IMF WEO April 2003 database; Annex 1, Table 12.1.

\section{People have moved to higher-income cities}

Higher-income cities have been acting as magnets for migrants from rural areas. Across the metropolitan areas considered here, a level of GDP per capita $10 \%$ above the average in 2000 has been associated with a $1.5 \%$ increase in population through 2010 . In 2000, the largest cities already tended to have the highest incomes and so they have tended to see their population grow fastest (Figure 4). Indeed, just $5 \%$ of cities which had the largest population in 2000 accounted for over $60 \%$ of the absolute increase in the population of all the selected metropolitan areas (Figure 5), despite policy efforts to constrain the growth of large and super-large cities. At the same time, policies to favour the growth of small and medium-sized cities have indeed spurred the growth of cities of below one million inhabitants. In contrast, nearly one third of the selected metropolitan areas saw their population shrink in the decade ending in 2010. Moreover, a further 145 experienced net outward migration, even though their population did not fall. 
Figure 4. Metropolitan areas: annual population growth and initial size

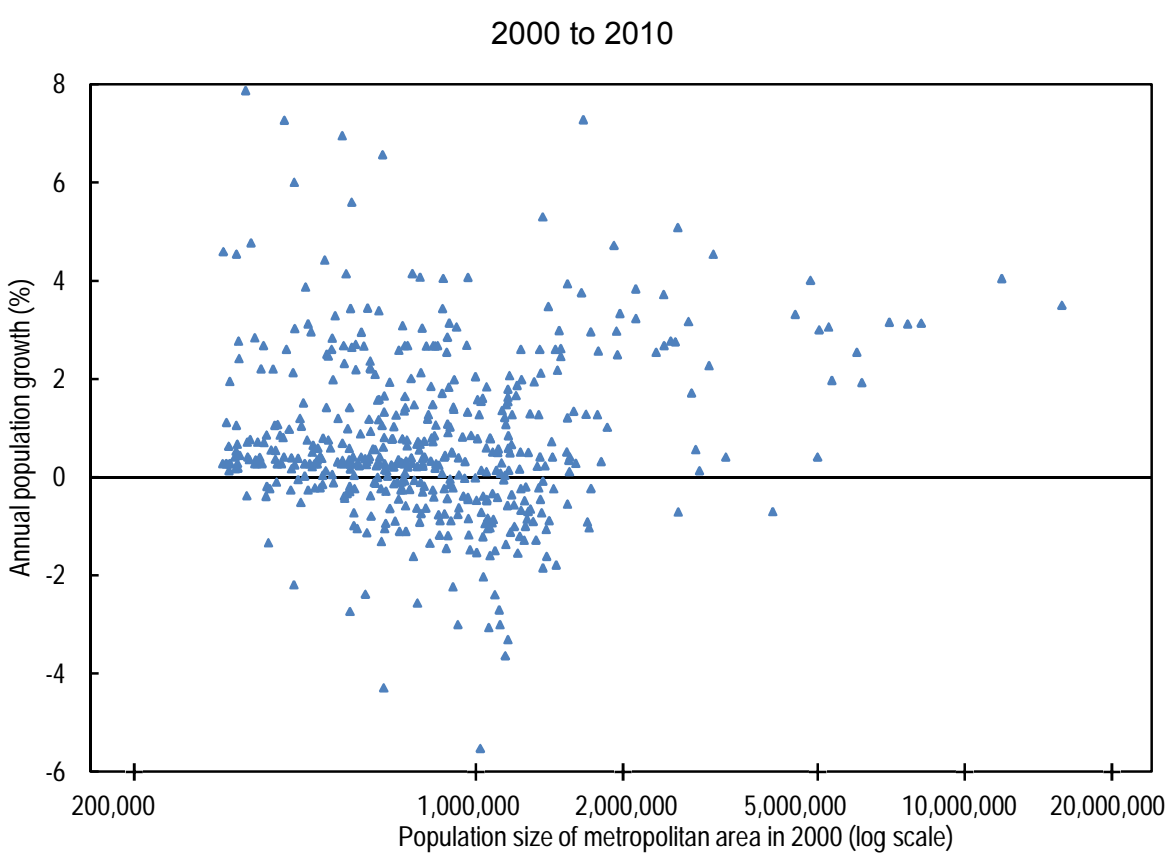

Source: National Bureau of Statistics: Statistical communiqués on the census issued by prefectural NBS offices.

Figure 5. The concentration of population increase across metropolitan areas

Increase from 2000 to 2010

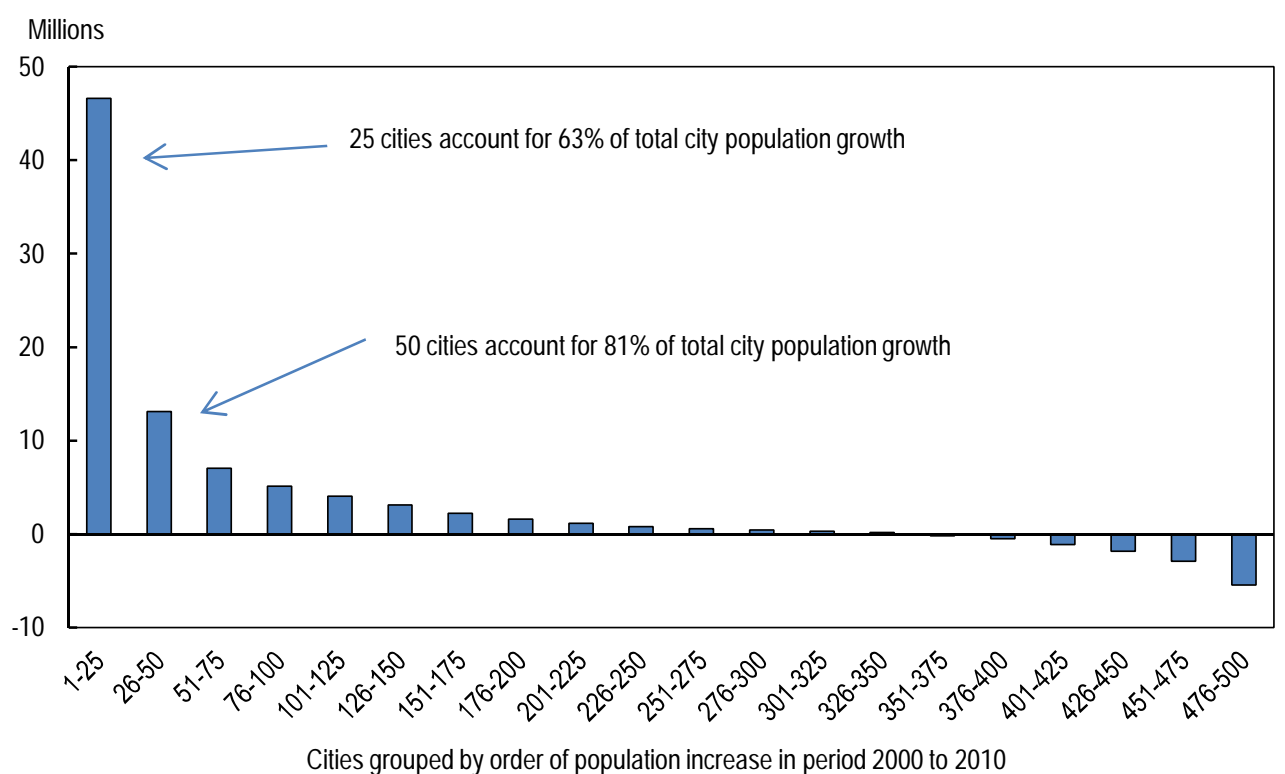

Source: OECD calculations using 2010 Census data. 


\section{But the urbanisation rate and size of cities remain relatively low}

With larger cities expanding faster than smaller cities the size distribution of Chinese cities has moved closer to that seen in the rest of the world (Table 2). The share of the population living in cities of over 8 million inhabitants has almost tripled but, reflecting constraints on the growth of very large cities, still remains well below the proportion of the population living is such large cities in the rest of the world.

Table 2. City size distribution: China and the rest of the world

\begin{tabular}{lrr|rr}
\hline \multirow{3}{*}{ City size } & \multicolumn{2}{c|}{$\mathbf{2 0 1 0}$} & \multicolumn{2}{c}{$\mathbf{2 0 0 0}$} \\
\cline { 2 - 5 } & China & \multicolumn{4}{c}{ World ex China } & China & World ex China \\
\cline { 2 - 5 } Over 2 million & 16.9 & As share of total population \\
Over 8 million & 5.9 & \multicolumn{4}{c}{ Number of cities per billion population } \\
\cline { 2 - 5 } Over 2 million & 33.6 & 23.0 & 26.6 & 5.7 \\
Over 8 million & 4.5 & 5.6 & 1.6 & 29.1 \\
\hline
\end{tabular}

Source: China 2010, 2000: National Bureau of Statistics Census communiqués and Census tabulations; World ex China 2010: Demographia (2012), 2000: Henderson and Wang (2004).

Despite the rapid growth of cities, the urbanisation rate in China is still somewhat below the level that might be expected on the basis of its per capita income (Figure 6). Indeed, the gap has barely changed in the past decade. The question remains whether urbanisation is a driver of income growth or whether higher incomes result in people wanting to move to cities, or whether it reflects the decline of the agricultural sector as a country develops. While estimating the agglomeration economies due to urbanisation is difficult, there is a robust consensus that such economies are substantial (Glaeser and Gottlieb, 2009).

Figure 6. Urbanisation and level of income worldwide



Source: World Development Indicators (IBRD) and National Bureau of Statistics. 


\section{Urbanisation has brought considerable benefits}

\section{Productivity and living standards are higher in large metropolitan areas}

Agglomeration economies allow larger cities to be more productive, and explain that growth tends to be concentrated geographically. While urbanisation is thus a powerful engine of growth, it also brings other welfare gains, including by improving the variety of available goods and services for consumers (Glaeser, 2011). Moreover, agglomeration benefits obtain even when individual metropolitan areas are not completely contiguous. To wit, GDP per capita is very high in several urban corridors or clusters of cities, such as the two corridors running north-west and south-east of Shanghai. In all, there may be between 28 and 53 such areas across China (Kamal-Chaoui et al., 2009).

As with the increase in population, the creation of value-added is concentrated across cities. Indeed, $40 \%$ of the GDP produced in the 515 metropolitan areas stemmed from the top 25 ones in 2010, where on average GDP per capita, at purchasing power parity, was equivalent to Portugal's (Figure 1). The following 75 metropolitan areas produced a further 30\%. The concentration of GDP is more extreme than that of population because the larger cities also display higher productivity. As with population, the extent of the concentration of GDP has increased somewhat since 2000. Even allowing for the differences in prices between urban and rural areas, the higher income levels in cities translate into higher living standards.

City size is a major determinant of income per capita, even if a simple correlation between the two can be misleading. Many factors influence city competitiveness (OECD, 2006): cities that were initially more productive thanks to a favourable physical location or political supremacy, for example, may have accumulated more capital; better educated people may have moved to larger cities, raising productivity. Focusing on size, two approaches have been used in the literature on Chinese cities: one used size as an input to explain the productivity of a city (Wang and Xia, 1999), the other tried to allow for increased commuting times in bigger cities (Au and Henderson, 2006). These two approaches gave very different results. Wang and Xia found that productivity gains outweighed external costs (as measured by government expenditure) until cities reached a size of 10 million people. Au and Henderson found that net of external costs associated with city size the productivity of cities peaked at a size of around 1 million. They concluded that most cities were undersized but a few were oversized, even in 1999. However, both studies used registered rather than actual city population, thereby overstating the extent of agglomeration economies since migrants are predominately in large, high-income cities.

Even so, the relationship between city size and productivity (proxied by GDP per capita) is fairly robust in China. In the largest ten (2\%) metropolitan areas, GDP per capita is nearly $60 \%$ higher than in the bottom $2 \%$. One major factor that can explain the differences in productivity across cities is the amount of capital available per person. The total capital stock in each of the chosen metropolitan areas cannot be measured. However, for the major areas the total fixed assets of industrial enterprises is available and can serve to proxy the total capital stock in a city. Using the actual population, as given by the 2010 census (rather than the registered population), as a proxy for employment, a simple Cobb-Douglas production function can be estimated and yields a capital share in income of 0.47 . This estimate is in line with the results of macro-economic production functions and with income shares, as well as with the estimates in the two above studies.

Once the inputs of capital and labour are accounted for, there remain significant differences in productivity across cities that are correlated with city size (Figure 7): there is a clear positive relationship between the productivity that is unexplained by a standard Cobb-Douglas production function approach and population size. There are diminishing returns, however: the gain in efficiency from moving from a population of 400000 to a population of 500000 is much greater than the gain from moving from 20 million to 25 million. 
Figure 7. Total factor productivity and city size ${ }^{1}$

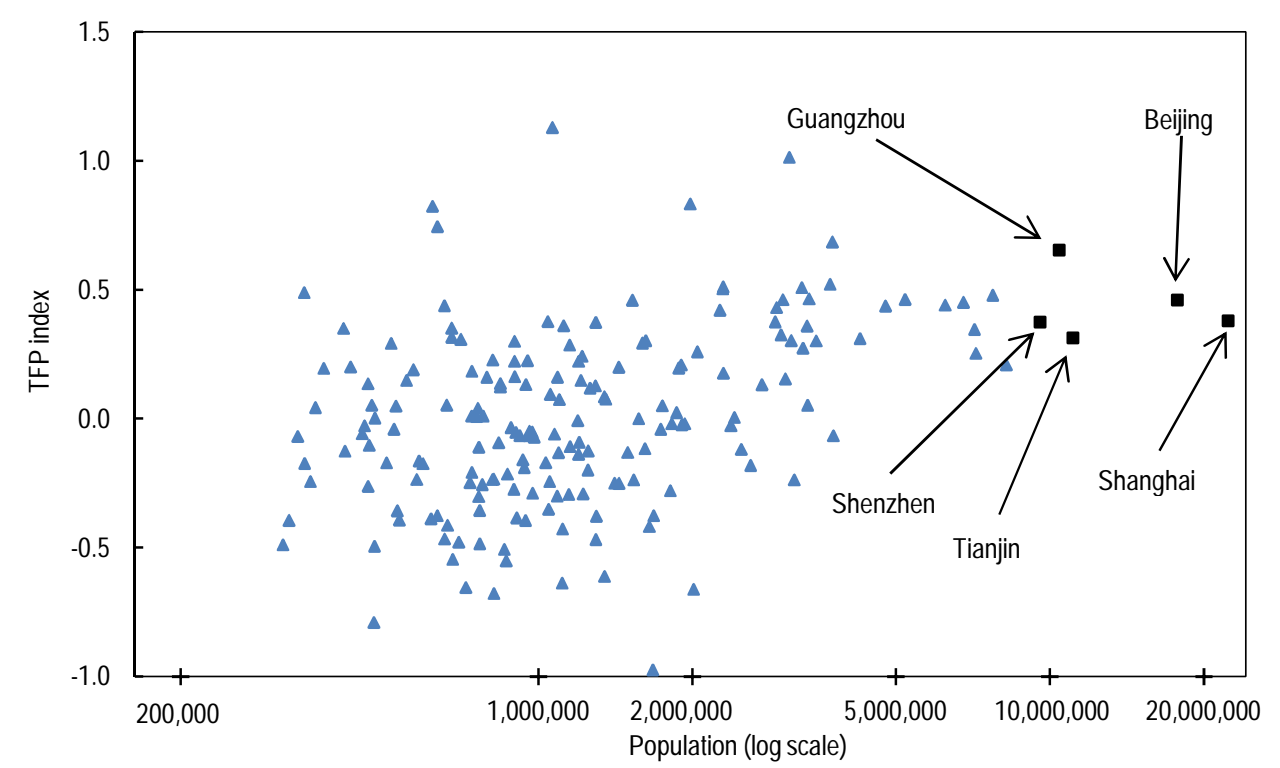

1. The vertical axis of this chart shows the residual from an estimated Cobb-Douglas production function where the labour and capital coefficients have been constrained to add to unity. Employment has been proxied by population and capital by industrial sector fixed assets. The equation has been estimated over 180 metropolitan areas for which a full dataset was available in 2010.

Source: Authors' calculations.

It might be that as cities increase in size, efficiency stabilises or even starts to fall. In order to assess whether this might be the case in China, the average efficiency gain as size increases for cities with a population between 300000 and 9 million has been used to estimate the average efficiency level in the five largest cities in China (Beijing, Guangzhou, Shanghai, Shenzhen and Tianjin). Actual efficiency levels in the mega-cities turn out to be in line with this relationship, except for Shanghai, the largest metropolitan area, where it is lower. This need not be related to size, however. Other factors affect the efficiency of a city, such as the business environment and economic model pursued by the local government.

Across OECD countries, the relationship between city size and productivity is much looser. There is some evidence that productivity rises with city size up to a population of around 6 million and then starts to decline - exceptionally large cities (so-called "mega-cities") may become "dysfunctional" (OECD, 2006). However, the relationship is extremely weak and barely statistically significant. One reason for the differences in the productivity relationship between cities in China and those in the OECD area may lie in the non-market barriers to city expansion in China both in the labour market and in the land market where administrative hurdles have, in the past, tried to restrict migration so preventing wage equalisation across the country and even within provinces (OECD, 2010a).

Such evidence as is available from outside China points to economies of scale in administration costs. In 635 Japanese cities, the cost per capita of providing public services was shown to decline with size (Nakamura and Tahira, 2008). When looked at by cost centres for a sub-sample of around 130 cities, increasing returns to scale were most noticeable in areas involving infrastructure but could also be important in the provision of some social services (Table 3 ). 
Table 3. Elasticity of public expenditure per capita with respect to population size

\begin{tabular}{lccc}
\hline Prefecture & Sanitation & Civil engineering & Education \\
\cline { 2 - 4 } Hyogo & -0.101 & -0.189 & -0.117 \\
Osaka & -0.573 & -0.531 & -0.598 \\
\hline
\end{tabular}

Source: Nakamura and Tahira (2008).

\section{Compact cities are energy efficient but industrial parks have proliferated}

Cities in China tend to be compact and compactness can contribute to urban sustainability in many, mutually reinforcing ways (OECD, 2010b). The dense and proximate development patterns of compact cities reduce the intra-urban travel distances, result in a lower level of automobile dependence and offer the possibility of more district-wide energy utilisation and local energy generation (Matsumoto and SanchezSerra, 2012). Several studies in OECD countries have shown that it is the density rather than the overall size of a city that is important in reducing carbon dioxide emissions and this also appears to be the case in China, where cities are far denser than in the OECD area (Figure 8).

Figure 8. Carbon emissions from ground transport per capita and population density

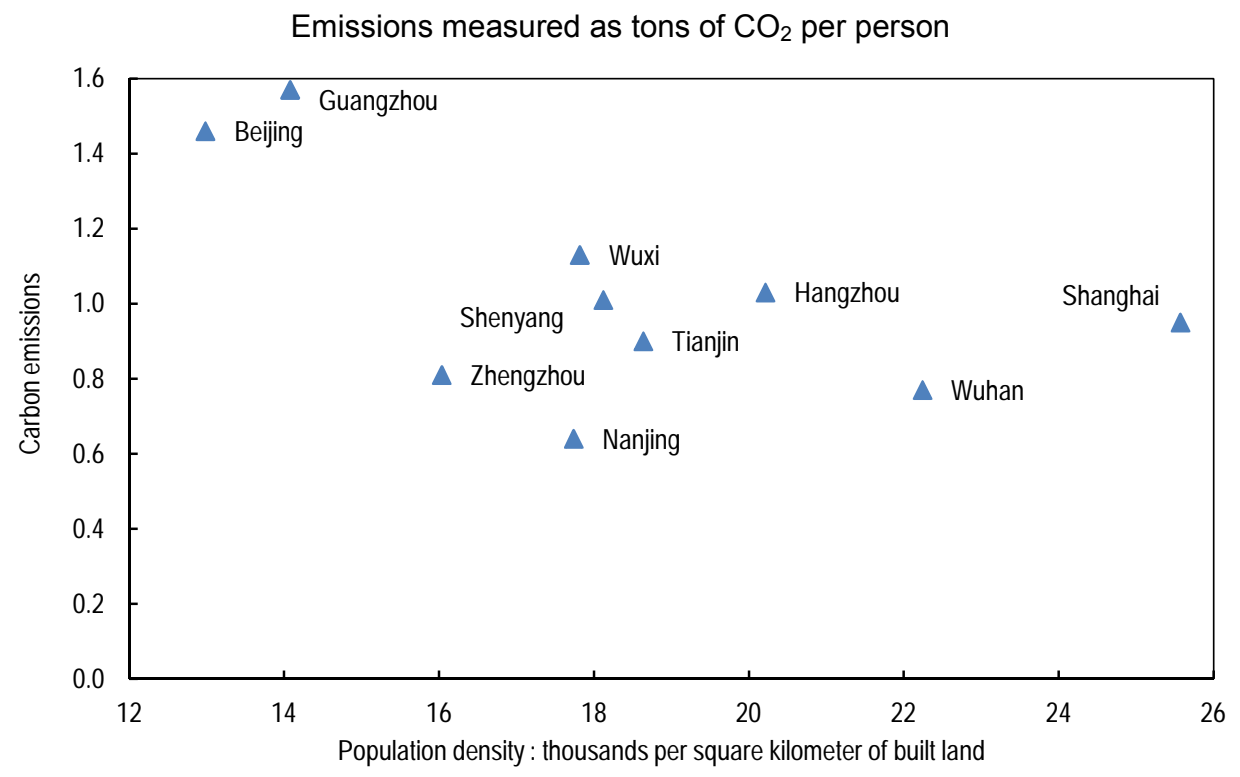

Source: Wang et al. (2012).

However, while cities are relatively compact, standalone industrial and mining sites have proliferated. During the initial stages of China's economic take-off, national development zones were a key source of growth. Following their success, most local authorities, down to the county level, created similar zones or industrial parks. By 2003, there were nearly 7000 zones covering an area nearly $30 \%$ greater than the then built-up area of the country. Even though the government closed many of the undeveloped zones, standalone industrial and mining sites still cover vast areas, using up more land than cities and designated towns (Zhang, 2011, He et al., 2012). The central government is concerned that frantic industrial land development by local government may lower the efficiency of land use and give rise to excessive demand for transport. 


\section{Mitigating the costs associated with urbanisation}

While urbanisation brings a number of benefits, it also has costs, especially beyond a certain size. One relates to congestion, which can be alleviated through congestion charging (Hill, 2013) and by developing the transport network and providing adequate public transport infrastructure. Cities also regroup many industries and generate more trips than rural areas, so generating an increase in emissions of pollutants. However, the evidence from Europe is that the external costs of emissions do not rise in line with city size. As a result, the per capita external cost of pollution tends to fall with increases in city size beyond a relatively low threshold (Holland and Watkiss, 2004). Moreover, if appropriate pollution taxation is introduced, the externalities can be internalised and reduced, making the city more attractive (Henderson, 1974).

\section{Public transport provision has fallen behind urbanisation}

Public transport policy began to change a few years ago. In 2006, the NDRC, Ministry of Finance, Ministry of Construction and Ministry of Labour jointly spelled out guidelines to cities on the Economic Policy for Priority Development of Urban Public Transport. In 2007, the State Council made increasing public transport use a key element of its Comprehensive Energy Reduction Work Programme. However, at city level, there is often no integrated structure for achieving this goal: responsibilities are spread over many departments (Pan, 2011).

The $12^{\text {th }}$ Five Year Sub-Plan for Transport calls for the orderly construction of light rails, subways, tramcars, and so forth, and for urban rail transit networks based on differentiated targets reflecting size and characteristics. Cities with a population of over 10 million should gradually enhance their existing urban rail transit network, cities over 3 million should establish a framework for an urban rail transit network, and cities over 1 million should construct large-capacity ground public transport systems as needed. The government has an objective of raising the market share of public transport to $40 \%$ by 2015 .

A considerable deficit in provision needs to be overcome. In the ten largest cities, the average rail density per square kilometre is only one quarter that in major urban areas outside of mainland China and the density per million people is only one fifth (Table 4). In these ten areas, bringing rail density up to world averages would require constructing 5000 kilometres of track. The new metro system in Hangzhou is expected to cost CNY 0.9 billion per $\mathrm{km}$ ( $\$ 140$ million), far less than new subways systems in Europe. Even so, the cost of bringing the ten major Chinese cities up to the world level of provision, given their population in 2010, would amount to CNY 4.5 trillion (11\% of 2010 GDP).

With around 20 million people migrating to urban areas each year, the target for public transport will need to be raised. If the experience of the past ten years were repeated, just over half of the increase in urban population would take place in the 50 cities with a population currently at or close to 2 million. The density in the smallest quarter of these cities (in terms of population per square kilometre of built area) may not be high enough to justify metros as it is well below the 15000 threshold considered necessary for a subway system. Even so the built area of the largest three-quarters of these cities is likely to expand at least in proportion to population, creating the need for around another $1500 \mathrm{~km}$ of urban railways. Starting with the stimulus plan of 2008 and continuing with the announcement of projects authorised under the $12^{\text {th }}$ Plan, the government has given the green light for the construction and extension of subways in 33 cities, which will bring the total number of cities with subways to 35 (Table 5). The effort is being undertaken at a time when the level of economic development in major cities is in line with that in the United Kingdom and France when their subway lines were largely completed. In the following five years, construction is projected to continue apace and by 2030 the total length of all networks may approach $11000 \mathrm{~km}$. The eventual expected availability and density of the networks varies considerably across cities. A number of smaller ones have objectives in terms of availability and density that are well above those found in bigger cities. There may thus be a degree of over-investment in subway networks in smaller cities. 
Table 4. Rail transport systems in large metropolitan areas

As of 2012

\begin{tabular}{|c|c|c|c|c|c|c|c|c|}
\hline & \multicolumn{3}{|c|}{ Length of transport system } & \multicolumn{3}{|c|}{ Demographic indicators } & \multicolumn{2}{|c|}{ Transport indicators } \\
\hline & $\begin{array}{c}\text { Commuter } \\
\text { rail }\end{array}$ & Subway & Total & $\begin{array}{l}\text { Popula- } \\
\text { tion }\end{array}$ & Area & Density & Availability & Density \\
\hline & \multicolumn{3}{|c|}{ Kilometres } & million & $\mathrm{km}^{2}$ & $\begin{array}{c}\text { people/ } \\
\mathrm{km}^{2}\end{array}$ & $\begin{array}{l}\mathrm{km} / \mathrm{million} \\
\text { people }\end{array}$ & $\begin{array}{c}\text { metres/ } \\
\mathrm{km}^{2}\end{array}$ \\
\hline \multicolumn{9}{|c|}{ Outside mainland China } \\
\hline Hong Kong, China & 0 & 174 & 174 & 7 & 275 & 25455 & 25 & 633 \\
\hline London & 1912 & 436 & 2348 & 12 & 4144 & 2951 & 192 & 567 \\
\hline Osaka-Kobe-Kyoto & 1095 & 234 & 1329 & 15 & 2719 & 5608 & 87 & 489 \\
\hline Paris & 1012 & 213 & 1225 & 10 & 2745 & 3515 & 127 & 446 \\
\hline Seoul/Incheon & 249 & 701 & 950 & 23 & 2163 & 10402 & 42 & 439 \\
\hline Tokyo-Yokohama & 1779 & 360 & 2139 & 31 & 5258 & 5934 & 69 & 407 \\
\hline Singapore & 0 & 147 & 147 & 5 & 466 & 10944 & 29 & 314 \\
\hline Nagoya & 528 & 89 & 617 & 8 & 2823 & 2851 & 77 & 219 \\
\hline New York & 979 & 456 & 1435 & 20 & 11137 & 1823 & 71 & 129 \\
\hline Taipei & 0 & 110 & 110 & 8 & 1140 & 7281 & 13 & 96 \\
\hline \multicolumn{9}{|l|}{ Mainland China } \\
\hline Shanghai & 56 & 312 & 368 & 22.3 & 2825 & 5776 & 16.5 & 130.3 \\
\hline Guangzhou & 0 & 232 & 232 & 10.4 & 1953 & 5263 & 22.3 & 118.8 \\
\hline Tianjin & 0 & 131 & 131 & 11.1 & 1400 & 5166 & 11.8 & 93.6 \\
\hline Shenzhen & 0 & 178 & 178 & 9.6 & 2505 & 6579 & 18.5 & 71.1 \\
\hline Beijing & 86 & 372 & 458 & 17.7 & 7537 & 4804 & 25.9 & 60.8 \\
\hline Fosham & 0 & 20 & 20 & 6.8 & 333 & 20420 & 2.9 & 60.1 \\
\hline Wuhan & 0 & 56 & 56 & 7.7 & 1024 & 7520 & 7.2 & 54.7 \\
\hline Chongqing City & 0 & 87 & 87 & 7.5 & 1774 & 7979 & 11.6 & 49.0 \\
\hline Nanjing & 0 & 87 & 87 & 7.2 & 2741 & 4758 & 12.1 & 31.7 \\
\hline Dalian & 0 & 63 & 63 & 3.4 & 3068 & 7930 & 18.5 & 20.5 \\
\hline
\end{tabular}

Source: Various.

As cities become larger, the strategy may need to change from building subway systems to building commuter rail systems that have less frequent stations and hence achieve faster journey times from the more distant parts of cities. In Beijing, a commuter rail system is being developed. It is not managed by the urban transport system but by a subsidiary of the Ministry of Railways. By 2020 it is expected to be of a similar size to the current metro network.

A newer development has been the growth of bus rapid transport (BRT) systems but this has not been sufficient to improve the overall availability of buses. Eleven cities now have BRT, with dedicated lanes for buses on existing highways or in some cases on newly-built roads. The total length of these systems is very modest, at around $650 \mathrm{~km}$, and BRT is not widespread yet: one third of the Chinese network is in a single city, Guangzhou, where the $22 \mathrm{~km}$ dedicated route carries slightly over 800000 passengers per day and has quickly paid back its investment. This passenger flow is greater than that on all but two metro lines in China and equivalent to $40 \%$ of the entire number of bus riders in New York City (Hughes and Zhu, 2011). This experience replicates success in other cities where BRT delivers high passenger flows at relatively low cost (Suzuki et al., 2011). However, local governments have not invested sufficiently in this form of public transport. The overall number of buses grew by $5.4 \%$ per year between 2000 and 2010 , barely faster than the growth of built land in metropolitan areas. By contrast the road area grew by $8.4 \%$ annually and the number of privately owned cars at an annual rate of $25 \%$. 
Table 5. Existing and planned subways in China

\begin{tabular}{|c|c|c|c|c|c|c|c|c|}
\hline & $\begin{array}{l}\text { Population } \\
\text { of urban } \\
\text { districts } \\
2010\end{array}$ & Area & $\begin{array}{c}\text { Length of } \\
\text { subway and } \\
\text { commuter } \\
\text { rail network } \\
\text { as of } 2012 \\
\end{array}$ & $\begin{array}{l}\text { Length of } \\
\text { projects } \\
\text { under } \\
\text { construction }\end{array}$ & $\begin{array}{c}\text { Planned } \\
\text { over the } \\
\text { longer } \\
\text { haul }\end{array}$ & $\begin{array}{c}\text { Eventual } \\
\text { target } \\
2020 \text { or } \\
2030\end{array}$ & $\begin{array}{c}\text { Eventual } \\
\text { availability } \\
\text { of network }\end{array}$ & $\begin{array}{c}\text { Eventual } \\
\text { density of } \\
\text { network }\end{array}$ \\
\hline & million & $\mathrm{km}^{2}$ & $\mathrm{~km}$ & $\mathrm{~km}$ & $\mathrm{~km}$ & $\mathrm{~km}$ & $\begin{array}{l}\mathrm{km} \text { per } \\
\text { million } \\
\text { people }\end{array}$ & $\begin{array}{l}\text { metres } \\
\text { per } \mathrm{km}^{2}\end{array}$ \\
\hline Foshan & 6.8 & 333 & 20 & 139 & 107 & 266 & 39.1 & 799 \\
\hline Wuhan & 7.7 & 1024 & 56 & 63 & 411 & 530 & 68.8 & 518 \\
\hline Zhengzhou & 4.3 & 455 & 0 & 53 & 149 & 202 & 47.0 & 444 \\
\hline Guangzhou & 10.4 & 1953 & 232 & 318 & 291 & 841 & 80.9 & 431 \\
\hline Fuzhou & 2.9 & 556 & 0 & 55 & 129 & 184 & 63.4 & 331 \\
\hline Shanghai & 22.3 & 2825 & 368 & 202 & 307 & 877 & 39.3 & 310 \\
\hline Taiyuan & 3.4 & 839 & 0 & 49 & 187 & 236 & 69.4 & 281 \\
\hline Dongguan & 8.2 & 1088 & 0 & 37 & 227 & 264 & 32.2 & 243 \\
\hline Shenyang & 5.2 & 1353 & 50 & 94 & 182 & 326 & 62.7 & 241 \\
\hline Nanjing & 7.2 & 2741 & 87 & 58 & 455 & 600 & 83.3 & 219 \\
\hline Tianjin & 11.1 & 1400 & 131 & 90 & 81 & 302 & 27.2 & 216 \\
\hline Ningbo & 3.5 & 478 & 0 & 21 & 80 & 101 & 28.9 & 211 \\
\hline Xi'an & 6.5 & 2868 & 21 & 75 & 501 & 597 & 91.8 & 208 \\
\hline Shenzhen & 9.6 & 2505 & 178 & 159 & 126 & 463 & 48.2 & 185 \\
\hline Nanning & 2.3 & 1014 & 0 & 32 & 146 & 178 & 77.4 & 176 \\
\hline Chongqing & 7.5 & 1774 & 87 & 128 & 86 & 301 & 40.1 & 170 \\
\hline Wuxi & 3.0 & 1460 & 0 & 58 & 188 & 246 & 82.0 & 168 \\
\hline Beijing & 17.7 & 7537 & 458 & 28 & 650 & 1136 & 64.2 & 151 \\
\hline Harbin & 4.8 & 1142 & 0 & 17 & 145 & 162 & 33.8 & 142 \\
\hline Hangzhou & 6.2 & 2465 & 0 & 49 & 230 & 279 & 45.0 & 113 \\
\hline Qingdao & 3.7 & 2081 & 0 & 54 & 177 & 231 & 62.4 & 111 \\
\hline Nanchang & 2.3 & 1622 & 0 & 50 & 118 & 168 & 73.0 & 104 \\
\hline Guiyang & 2.3 & 2129 & 0 & 55 & 142 & 197 & 85.7 & 93 \\
\hline Dalian & 3.4 & 3068 & 63 & 150 & 49 & 262 & 77.1 & 85 \\
\hline Suzhou & 1.6 & 1669 & 25 & 22 & 94 & 141 & 88.1 & 84 \\
\hline Wenzhou & 3 & 2908 & 0 & 51 & 184 & 235 & 78.3 & 81 \\
\hline Changchun & 2.9 & 3547 & 51 & 43 & 163 & 257 & 88.6 & 72 \\
\hline Kunming & 3.3 & 2612 & 18 & 83 & 86 & 187 & 56.7 & 72 \\
\hline Lanzhou & 2.5 & 2922 & 0 & 27 & 180 & 207 & 82.8 & 71 \\
\hline Hefei & 3.4 & 4727 & 0 & 56 & 266 & 322 & 94.7 & 68 \\
\hline Shijiazhuang & 2.7 & 1188 & 0 & 35 & 24 & 59 & 21.9 & 50 \\
\hline Xiamen & 2.3 & 5155 & 0 & 31 & 215 & 246 & 107.0 & 48 \\
\hline Chengdu & 7.1 & 5473 & 40 & 67 & 143 & 250 & 35.2 & 46 \\
\hline Changsha & 3.1 & 2560 & 0 & 46 & 60 & 106 & 34.2 & 41 \\
\hline Changzhou & 3.3 & 7128 & 0 & 54 & 75 & 129 & 39.1 & 18 \\
\hline Total & 197.5 & 84599 & 1885 & 2549 & 6654 & 11088 & 56.1 & 131 \\
\hline
\end{tabular}

While there are no statistics on average daily commuting times in all Chinese cities, in Beijing and Shanghai, they are 79 and 69 minutes respectively (Zhaopin et al., 2012), well above the OECD average of just under 40 minutes and higher than in Korea, the OECD country where commuting takes up most time (OECD, 2011). The development of high-volume urban transport systems has not kept pace with city growth, leading to excessive growth in the number of cars. In Shanghai, though, new car owners have to purchase a licence plate in an auction, at a cost that in spring 2013 exceeded $\$ 14000$ per car. Use of effective pricing could reduce the extent of congestion to an efficient level. Indeed, in August 2013 the Beijing government announced a plan to introduce time-varying congestion charging. 


\section{Housing and land}

\section{Demand for living space has been rising}

Since the liberalisation of the housing market the average floor space occupied by an individual has steadily increased, helped by a decline in average household size. It is difficult to be precise about the extent of the improvement. Survey data are available but in urban areas they exclude migrants, whose housing demand is much lower (e.g., in Beijing, their average floor space is just $8.2 \mathrm{~m}^{2}$, against $27 \mathrm{~m}^{2}$ for official residents, according to Zheng et al., 2009). It is possible to estimate the total floor area of housing from new construction data but these suffer from another defect. The official data only counts housing on state land and not that on collective land within cities. Such housing is always considered by the government as rural even if it is quite clearly urban in the normal meaning of the word. This anomaly stems from the legal distinction between rural and urban land. The former is owned by the village council on a collective basis whereas in the historic urban areas, land is owned by the state. As cities have expanded the urban areas have surrounded rural areas. A significant proportion of what by appearance and location is urban land is officially classified as rural land. In many major cities, developed collectivelyowned land is equivalent to one-third of the area of developed state-owned land.

Given the conflicting definitions of urban and rural in different official statistics, the most effective way to assess the increase in overall living space is to use a national average. Based on initial average living space data for 1978 (when this distinction was of little importance due to the smaller size of cities and the near absence of migration), and the subsequent construction of new property and demolition of existing buildings, the average living space gross floor area available to an individual has increased from around $7.5 \mathrm{~m}^{2}$ to around $22 \mathrm{~m}^{2}$ in 2011, very much in line with the growth of real incomes (Figure 9).

Figure 9. The relationship between living space and GDP per capita

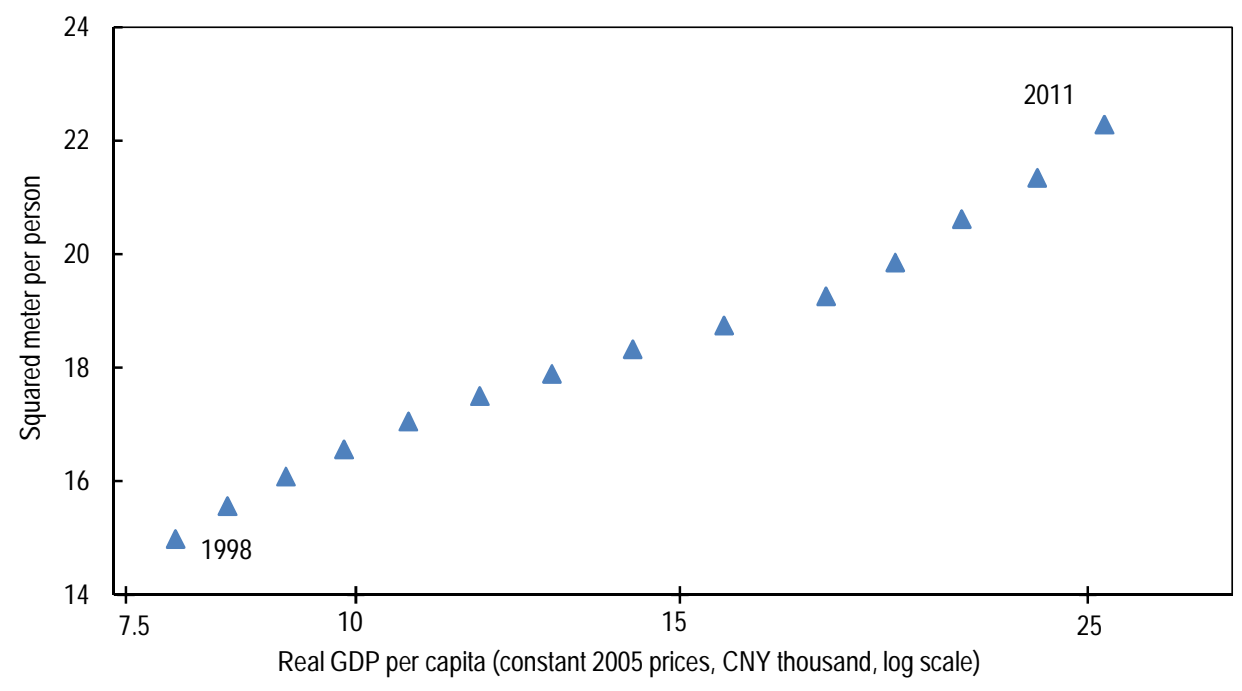

Source: CEIC, NBS and OECD calculations. 
Demand for housing space has, however, increased less than in other East Asian countries: in China, a one percentage point increase in income has been associated with an increase of living space of $0.06 \mathrm{~m}^{2}$, compared with a gain of 0.13 to $0.25 \mathrm{~m}^{2}$ in a cross-country panel (Berkelmans and Wang, 2012). This is probably related to the scale of internal migration in China. As the income of migrants rises, their incremental demand for housing is extremely low (less than one quarter of the increase registered for official urban residents). Even so, with rapid per capita income growth since the liberalisation of the housing market in 1998, per capita absolute housing demand has risen by $0.5 \mathrm{~m}^{2}$ per year, equivalent to a demand increase of $23 / 4$ per cent annually.

\section{And people prefer lower-density living}

The fall in population density has been concentrated in the metropolitan areas with the highest initial population densities: where population density was initially low (below 10000 people per $\mathrm{km}^{2}$ ), it has in fact often increased (Figure 10). This is in line with studies showing that higher wage levels are associated with lower densities and with studies of local housing prices showing that high plot ratios for apartment developments lower housing prices.

Figure 10. Change in population density and initial density

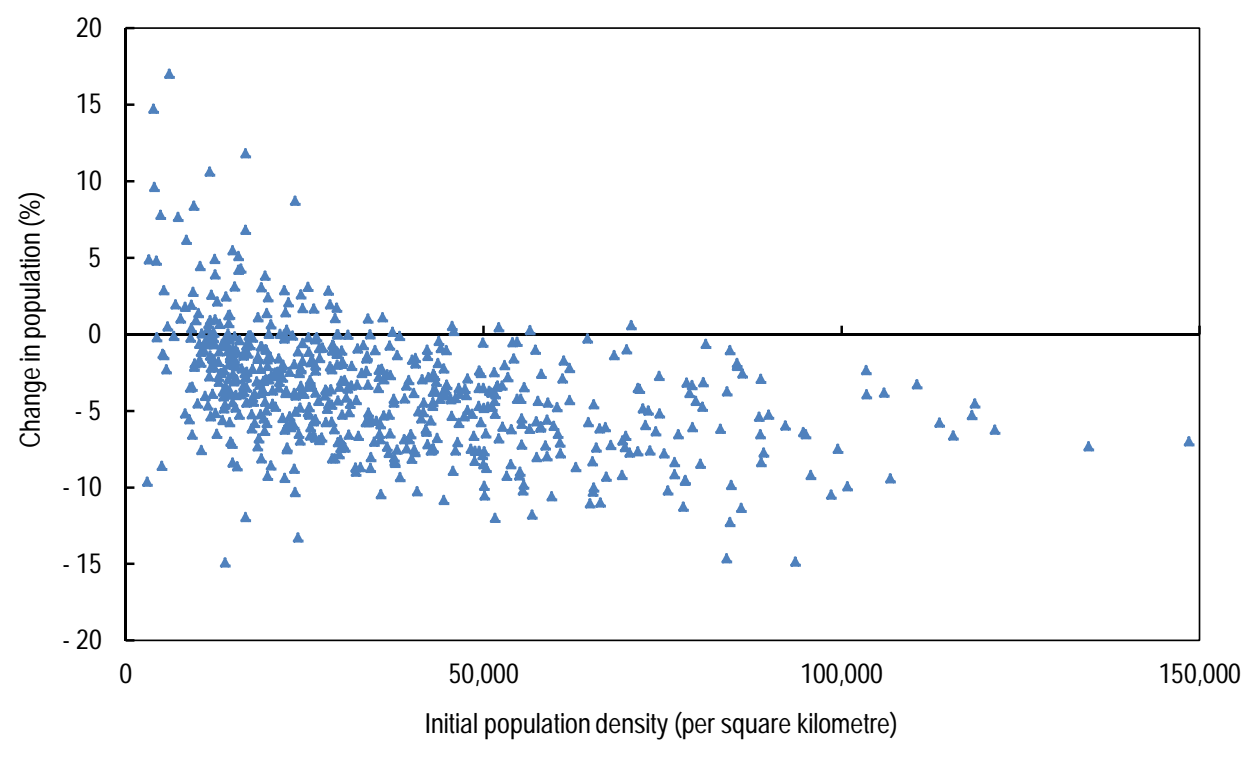

Source: National Bureau of Statistics census communiqués.

Densities are likely to continue to decline in a number of major urban areas for many decades. In the Pearl River Delta area, for example, the city of Dongguan has an average population density of 89000 per $\mathrm{km}^{2}$, while in certain areas of Shenzhen population densities are over 200000 per $\mathrm{km}^{2}$ of residential land (Wang, Wang and $\mathrm{Wu}, 2009$ ). Such high densities are unusual in developed countries and in China are a reflection of the small amount of space demanded by migrants and historical acceptance of dense living conditions. 
The extent of new and existing transport infrastructure has also been a key factor in lowering the very high densities formerly seen in Chinese city centres. In cities with one radial railroad line, $14 \%$ of central city output moves to the outskirts. Road networks have an even more pronounced impact on the location of people. Each ring road in Chinese cities results in a marked drop in the share of the city centre population in the prefecture and in an outward movement of industrial population (Baum-Snow et al., 2012). The latter tends to reduce the cost of central accommodation and so allows a greater influx of migrants. Indeed, the provision of a peripheral ring road to each prefectural city without such infrastructure in 2010 would likely raise the urban population by 50 million people (Baum-Snow and Turner, 2012). Moreover, the outward movement of production generated by rail networks benefits neighbouring rural areas, as documented in other studies of Chinese counties (Banerjee et al., 2012).

\section{Population growth has added to the demand for extra housing}

The growth in the population of cities has added to the demand for extra living space generated by higher incomes. Overall, population density has fallen (Table 6), mostly reflecting greater floor space per person. In the 515 metropolitan areas, almost $52 \%$ of the increase in the built area between 2000 and 2010 has been the result of an expansion in the average living space, while population increase has accounted for $44 \%$. In county-level cities, population growth has not contributed much to demand for land, which has rather resulted from a decline in the building density and an increase in average floor space per person. The extent of land used for construction has been a major source of concern to the authorities in China. Yet, between 2000 and 2010, the overall increase in the use of land for construction in the 515 metropolitan areas has been just $1 \%$ of total arable land, bringing the total built-up area of theses region to just one fortieth of total arable land, with the average diameter of the built-up surface of these metropolitan areas rising from $9 \mathrm{~km}$ to $12 \mathrm{~km}$.

Table 6. Population and building densities for metropolitan areas

\begin{tabular}{|c|c|c|c|c|c|}
\hline & \multicolumn{5}{|c|}{ All metropolitan areas } \\
\hline & \multicolumn{5}{|c|}{ Annual average growth rate $2000-10$} \\
\hline & $\begin{array}{c}\text { All } \\
\text { densities }\end{array}$ & \multicolumn{3}{|c|}{ Higher densities } & $\begin{array}{l}\text { Lower } \\
\text { densities }\end{array}$ \\
\hline & \multicolumn{5}{|c|}{ Type of administrative city } \\
\hline & All & All & $\begin{array}{c}\text { Above } \\
\text { county level }\end{array}$ & $\begin{array}{c}\text { County } \\
\text { level }\end{array}$ & Other cities \\
\hline Population & 1.5 & 2.1 & 2.4 & 0.7 & 0.3 \\
\hline Floor space per person & 2.8 & 2.8 & 2.8 & 2.8 & 2.8 \\
\hline Total demand for floor space & 4.3 & 4.9 & 5.2 & 5.0 & 3.1 \\
\hline Total built area & 5.1 & 5.1 & 5.4 & 6.5 & 3.9 \\
\hline Building density & -0.8 & -0.2 & -0.2 & -1.5 & -0.8 \\
\hline Population density & -3.4 & -3.3 & -2.8 & -5.5 & -3.5 \\
\hline \multicolumn{6}{|l|}{ Memorandum items } \\
\hline $\begin{array}{l}\text { Built-up land as share of } \\
\text { cultivated land }(\%)\end{array}$ & 3.1 & 2.4 & 2.1 & 0.3 & 0.8 \\
\hline Number of areas & 631 & 305 & 192 & 113 & 326 \\
\hline Share of total population (\%) & 100 & 67.2 & 51.8 & 15.4 & 32.8 \\
\hline
\end{tabular}

Source: City Statistical Yearbook, Statistical communiqués for census results of individual cities. 


\section{Urbanisation and the demand for more space has pushed up housing investment}

Massive urbanisation has necessitated a marked increase in the resources devoted to housing. In the first 30 years of the new China housing was not seen as a priority. Indeed, it was not until 1981 that the average living space for urban dwellers recovered its level of the early 1950s. By then the average per capita living space was still only $4 \mathrm{~m}^{2}$ per capita, equivalent to around $8 \mathrm{~m}^{2}$ of gross floor area per person (see Annex A2 on the various measures of living space). After 1980, urban housing was given more emphasis but investment remained low, at around $2 \%$ of GDP. In rural areas, however, the liberalisation of agriculture and the migration to small towns and cities gave rise to a boom in rural housing that ended in the mid-1990s as migration to small towns fell back.

The urban housing market began to expand in the second half of the 1990s as land-use rights became marketable. Property developers entered the market, but initially few individuals bought their own apartment. Rather, housing units were still purchased by SOEs and allocated to their employees. But with the liberalisation of the housing market in the late 1990s investment in housing surged. Moreover, the nature of the market changed, with real estate developers selling apartments to individuals. Rural investment also grew rapidly. Two trends underpinned this boom: first, many rural areas were effectively engulfed by urban areas; secondly, migrant workers invested in a house in their village of origin.

Overall, the coincident boom in urban and rural housing pushed up investment in housing. There are no official data for residential fixed capital formation or for the housing capital stock. However, both series can be estimated from other official data sources (see Annex 2), and suggest that residential gross fixed capital formation rose to over 14\% of GDP by 2011 (Figure 11, Panel A). The share of investment in GDP is over three times that in OECD member economies, but with high capital consumption and rapid GDP growth the value of the housing (excluding land-use rights in China and land elsewhere) remains low in relation to developed economies and has been quite stable despite high net investment (Figure 11, Panel B). However, the estimates of gross fixed capital formation exclude the cost of transforming raw land, be it farmland or land that already has structures on it. This investment is undertaken by the government and included in the sale price of land (see below). A further factor causing the level of investment to be understated is that most Chinese apartments are sold either as shells or in a semi-finished state with the fitting-out spending borne by the acquirer. 
Figure 11. Residential investment and housing stock

Construction costs only
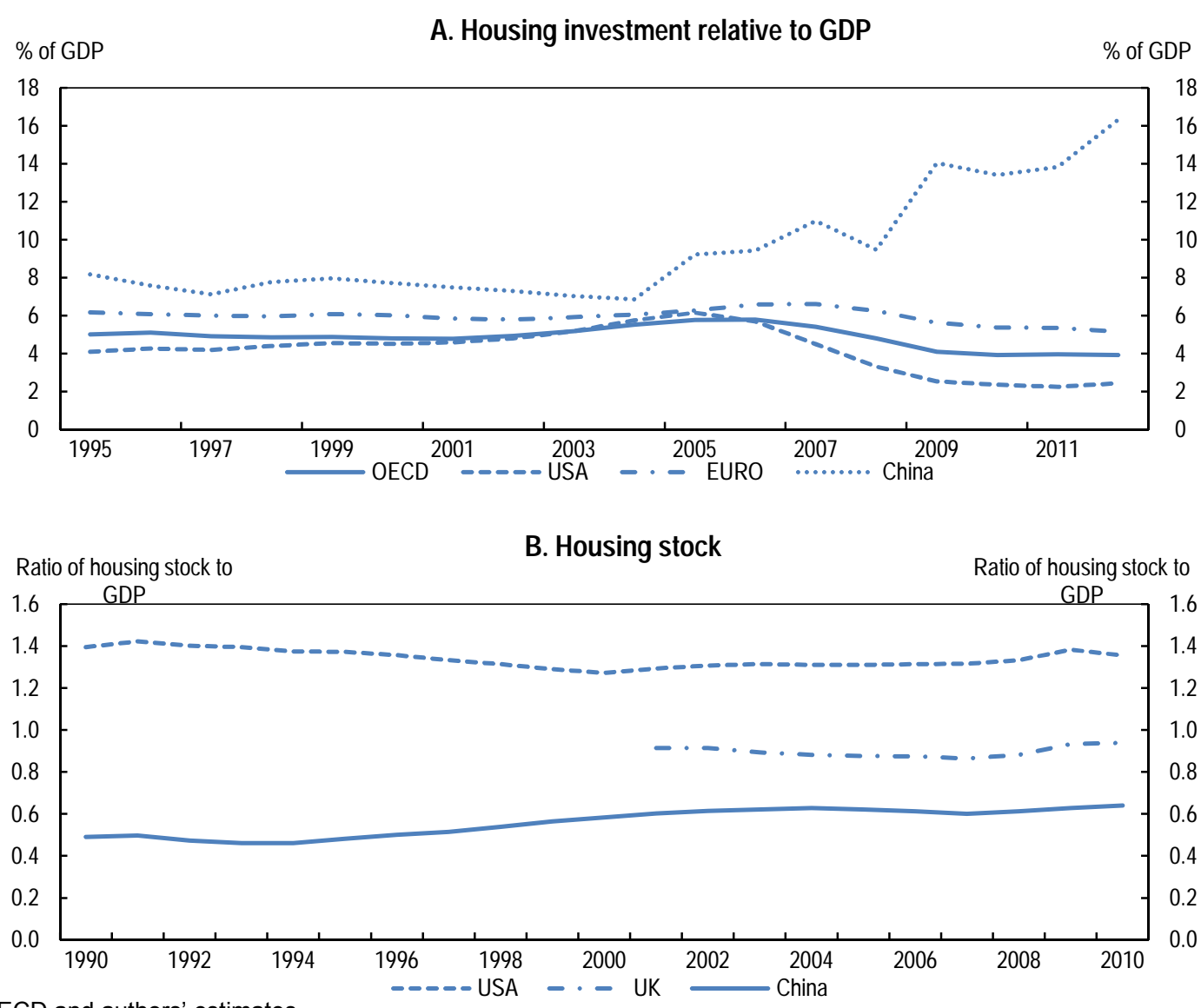

Source: OECD and authors' estimates.

The extent of investment in housing has raised concern that dwellings have been built in some areas without any underlying demand, giving rise to so-called ghost towns, e.g the new suburb of Kangbashi outside of Ordos in Inner Mongolia. There is no up-to-date information on the extent of vacant housing as the last housing Census in China was conducted in 1985.

Four types of vacant property can be considered: property under construction, property that has been finished and sold but is awaiting fitting-out by the owner, property that is completely finished, sold but left empty and finally property that is finished but unsold. Official information is only available on the last category of property. This type of vacancy is relatively limited since $75 \%$ of all property is sold before construction starts with payment being made in instalments. At the end of 2011 , there were approximately 2.5 million apartments awaiting sale. Given the normal plot ratio and the need to provide roads and public facilities, these apartments probably occupied around $200 \mathrm{~km}^{2}$ of land. While this may seems large, the unsold stock represented no more than three months of total sales, though a much higher proportion of sales of completed properties.

In a number of areas, the extent of new property that has been left unused has resulted in significant declines in prices, especially when there have been adverse developments in the local economy. In the new suburb of Ordos, major price declines of up to $70 \%$ have been reported as the local economy stumbled following declines in coal sales. Similarly in Wenzhou and in the province of Hainan significant falls have been reported. Nationally, however, after a short decline, prices rebounded. That said, any market where there are significant amounts of empty housing bought in anticipation of price increases remains vulnerable to changes in the economic outlook. 


\section{Responding to the demand for affordable housing}

After the government opened the housing market to private sector development in the $1990 \mathrm{~s}$, it created three programmes to ensure that certain groups in society were still able to access the housing market (Table 7). These programmes were based on the "Economic and Comfortable Housing" (ECH) plan. Under this plan, households satisfying certain criteria were eligible to buy apartments at below their market value. No cash subsidy was paid to households, rather the local government supplied land to a developer at no cost and the developer was obliged to keep the profit margin to $3 \%$. This programme was popular with local governments as it involved only foregone income from land sales rather than a cash outlay. However, it only benefitted relatively high income households. Eligibility for this programme was gradually tightened and by 2009 only $2.5 \%$ of housing was sold through this plan, down from $25 \%$ at the beginning of the decade.

Table 7. The Social Housing Programme of the 12th Plan

\begin{tabular}{llll}
\hline Sub-programmes & Target group & $\begin{array}{l}\text { Share in Social Housing } \\
\text { Programme under the 12th Plan }\end{array}$ & $\begin{array}{l}\text { Start of sub- } \\
\text { programme }\end{array}$ \\
\hline $\begin{array}{l}\text { Economic and } \\
\text { comfortable housing }\end{array}$ & Low income households & $12 \%$ & 1998 \\
$\begin{array}{l}\text { Price cap housing } \\
\text { Public rental housing }\end{array}$ & $\begin{array}{l}\text { Middle-income households } \\
\text { Low and moderate income, new } \\
\text { certain cities }\end{array}$ & $9 \%$ & 2007 \\
$\begin{array}{l}\text { Cheap rent housing } \\
\text { Resettlement from } \\
\text { demolished houses }\end{array}$ & $\begin{array}{l}\text { Very poor households } \\
\text { Owners of demolished house but } \\
\text { not tenants }\end{array}$ & $40 \%$ & 1994
\end{tabular}

Source: Zou (2014) and Ministry of Housing and Urban Development

Eventually, as eligibility for this programme was tightened, a new programme was introduced, the "Price-Cap Housing" (PCH) plan. Under this scheme, property developers bid for land but the local authority sets a cap on the sale price of the apartments. The main difference between the ECH and the PCH programme is that under the former the owner cannot resell the apartment for between five and seven years, whereas under the latter programme there is no lock-up period. This programme was unpopular with local authorities as they feared it would push down the price of land and so jeopardise their ability to build infrastructure with the proceeds of land-use right sales. The third of these programmes was designed to provide cheap rental dwellings. It was not popular with local governments because it imposed a considerable cash burden on their budgets both for construction and for subsequent maintenance which was generally not covered by rental income.

By 2007 about 4\% of the registered urban population lived in either ECH or PCH units with almost $70 \%$ of the households concerned falling in the in the upper-middle income group (the $5^{\text {th }}$ to $7^{\text {th }}$ decile of the urban household distribution) (Man, 2011).

Faced with the sharp rise in housing prices induced by the 2008/9 stimulus package, the government introduced a new social housing policy, sometimes known as an affordable housing policy. In total, the objective was to provide 36 million apartments during the period of the $12^{\text {th }}$ Plan. This policy aimed to expand the three programmes listed above and added a new programme called "Public Rental Housing". These four programmes were expected to produce around 22 million dwellings in the period 2011 to 2015. In addition, a further 14 million new units would be built as compensation for the demolition of low quality housing in urban areas, but situated on rural land and labelled as "shanty towns". The apartments 
designated as re-settlement compensation do not necessarily represent extra construction; as the housing law requires developers to compensate existing land use-right others with alternative accommodation, and sometimes with several apartments depending on the value of the use-right.

By June 2013, halfway through the programme, about one-third of the scheduled number of apartments had been completed, with total outlays on completed housing amounting to $2 \%$ of GDP over the same period. No detail of outlays under the various categories has been released. However, in 2010, the value of construction of economic housing, one of the components of the social housing plan, amounted to only $0.2 \%$ of GDP. Budgetary information also shows that outlays on subsidies for rental housing have increased substantially from $0.2 \%$ of GDP in 2009 to a $0.8 \%$ of GDP in 2012. Excluding the dwellings built as compensation for shanty town redevelopment, if the plan should result in an extra $10 \%$ of urban households living in one form or another of affordable housing.

\section{The role of government in urban development}

While the housing sector has become almost completely market oriented, government still plays a key role in urban development. Land in urban areas is owned by the state, which can either sell land-use rights or allocate them to third parties, or transfer them to companies wholly owned by the local government in exchange for equity in these companies. Once the market in land-use rights was established, local governments quickly realised that the powers given to them under the Land Management Act meant that they could control the supply of development land in their administrative area. This markedly changed the institutional structure from that which prevailed in the first decade of urbanisation in the 1990s, when there was a significant black market in the land occupied by SOEs which sold their use rights even though there was no legal basis for the transaction.

Local authorities were quick to establish a series of agencies known as land banks. These were not established as companies but as public service units (PSU - a form of government agency). In 1998, there were just 49 such units. Five years later, 1600 of the 2300 administrative units in the country had established such land banks (Yang et al., 2005). The focus of these agencies is generally land rather than city development. They acquire greenfield sites from village collectives and purchase existing structures for redevelopment in cities. Once either the land or the use-right has been acquired and the previous land users compensated, the PSU clears the land and installs basic urban infrastructure such as drainage, roads and utilities. Only then can a real estate promoter purchase the land-use right. Since 2007, land-use rights have to be sold by public auction or tender with the government setting a minimum reserve price. Local governments prefer to sell large development plots. In 2006, in Beijing, the average size of a lot was $55000 \mathrm{~m}^{2}$, about the size of four city blocks in a North American city. With a plot ratio of 2.5 and an apartment size of $120 \mathrm{~m}^{2}$, the average sales revenue from such a plot would be $\$ 450$ million with slightly more than 1000 units sold. Consequently, well capitalised firms dominated the property development market. The large size of plots is surprising in that, in Beijing, the larger the plot size the lower the land price (Bao et al., 2008). This could occur because there are fixed costs of dealing with permits. It could also reflect problems in the design of auctions for the sale of land-use rights. Some auctions are designed as two-stage processes and often in the second stage there is only one bidder, resulting in a lower price than in traditional English-style auctions. There is evidence that officials choose to place the larger and most attractive plots into two-stage auctions, so raising the likelihood of corruption (Cai et al., 2009).

Property developers have to comply with myriad of administrative procedures in order to start construction of commercial or residential projects (Box 1). In total, 33 procedures have to be followed, a number that is only exceeded in the Russian Federation. Overall, local experts estimate that the full procedure takes 311 days, in contrast to 26 days in Singapore and the United States; 30 days in Korea and 67 days in Hong Kong, China. Of 190 territories worldwide, only 15\% take longer than China to complete formalities (World Bank, 2012). 


\section{Box 1. Regulatory requirements for new construction}

- Submit application to obtain approval of the project proposal from the District Development and Reform Commission

- Request and obtain the approval of request of construction project planning and design from the competent Department of Urban Planning

- $\quad$ Request and obtain the approval of planning and design project for construction and the notification of the review of the design plan from the Urban Plan Department

- Request and obtain the Planning Permit of Using Land for Construction Purposes from the Urban Planning Administration Bureau

- $\quad$ Request and obtain the land using permit for construction from the State Land, Resources, and Housing Agency

- Request and obtain an environmental evaluation

- Request and obtain construction project planning permit

- Request and obtain certificate of safety operation on construction project at the Safety and Quality Supervision Office of the Municipal Construction Commission

- Request and obtain evidence of capital from bank

- Hire an authorised supervision agency

- Register construction drawings at the People's Civil Defence office

- Review of construction drawings by the City Appearance and Environmental Sanitation Administration Bureau

- Review of construction drawings by the Fire Protection Bureau

- Review of construction drawings by the Traffic Police District Level Team

- $\quad$ Obtain a letter of notice after review of building drawings by a building drawing examiner authorised by the Construction Project Document Review Centre

- Register for direct contracting of construction with the District Tendering Office

- Have the building contractor and supervisor seal the application form

- Pay the fees for funds of concrete and energy-saving wall materials with the Office of Building Materials of the Municipal Construction Commission

- $\quad$ Request and obtain building permit after having obtained all previous permits

- Receive on-site inspection by the Construction Commission

- $\quad$ Receive "Four-Party" Inspection from the site inspector, the designer, the builder and the supervisor

- Request and receive inspection of the completed construction from the planning department

- Request and receive the fire department inspection upon building completion

- Request opinion on whether the construction project is lightning-proof

- Request and obtain certificate of the completed construction from the fire department

- Request and receive inspection of the completed construction from the environmental protection department

- Request and receive inspection on construction completion and inspection from the Municipal Construction Committee

- Request and obtain certificate of completion and certificate of final inspection from the Municipal Construction Commission

- $\quad$ Register building with the Real Estate Registry

Source: World Bank (2012). 


\section{Land sales as a source of revenue}

During the period of strongly rising house prices from 2008 to 2010, the gross revenue flowing to local governments from the sale of land-use rights increased rapidly but it is difficult to trace the exact use of the money. Total revenue from the sale of land-use rights peaked at 7.3\% of GDP in 2010 (Figure 12). The allocation of this money is far from transparent. In 2011, according to the Ministry of Finance (2012), nearly four-fifths of the gross revenue of local government from land sales was spent either on compensation to previous owners/users or on redevelopment costs. The redevelopment work probably includes the standard public facilities on the land, such as schools, clinics and the like, the size of which is set down by law. A further $8 \%$ of total revenues were earmarked for specific purposes by legislation notably for creating new farmland. The surplus available for spending by the local authorities amounted to $18 \%$ of the gross revenue from sales $(1.3 \%$ of GDP) and represented $6.4 \%$ of total local government expenditure.

Figure 12. Gross revenue from sale of land-use rights

As percentage of GDP and of national tax and social security revenues

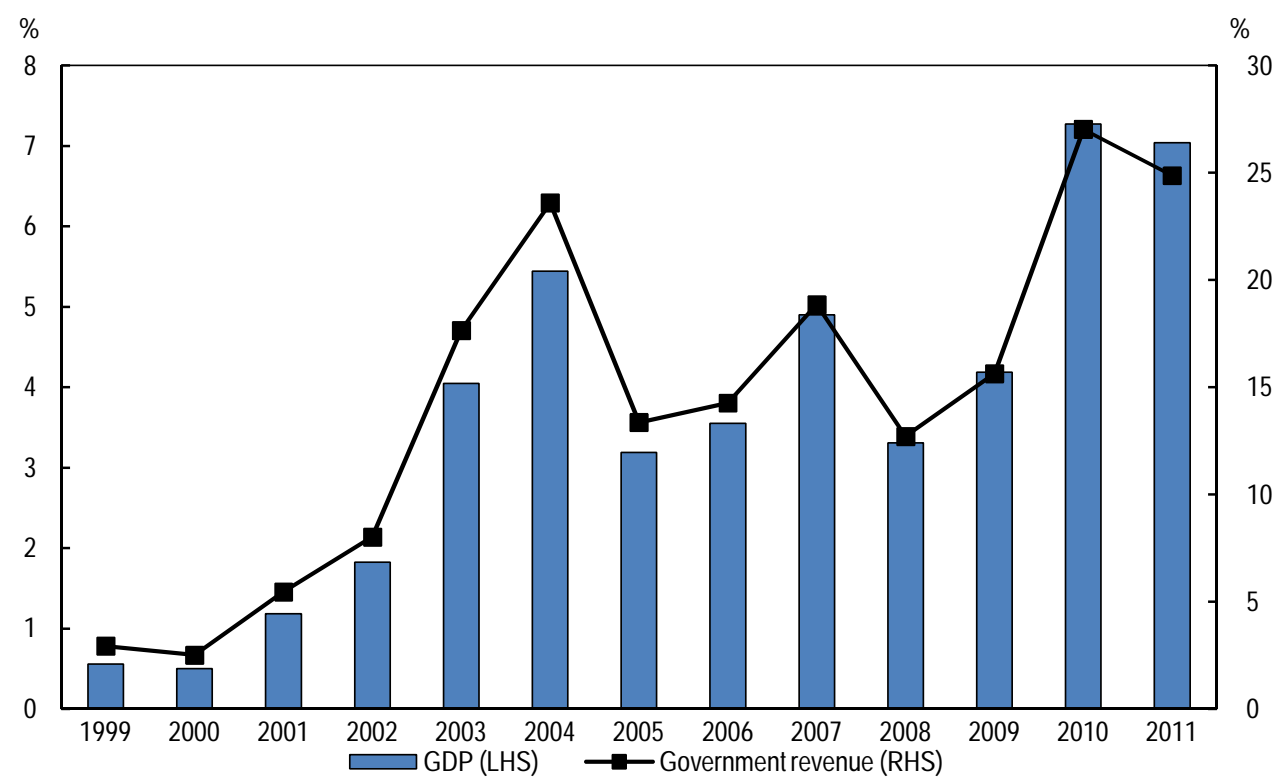

Source: Wu (2012).

\section{Where do the compensation funds go?}

The amount allocated for compensation and redevelopment, however, seems on the high side. No detail was given of who received this compensation, nor of the cost of land improvement, nor of the split between greenfield acquisitions and redevelopment. An example from the suburbs of Beijing shows that the compensation for the acquisition of collective agricultural land is less than one-tenth of the money raised from land-use rights. The compensation for collective land expropriation is, at the maximum, around 130 times the gross annual yield of the land. In the outer Beijing area, this formula gave compensation that at most amounted to around CNY 119 per $^{2}$ in $2011(\mathrm{Wu}, 2012)$. The price of the developed land, when auctioned, amounted to CNY 4600 per $^{2}$, so in this case compensation amounted to $2.6 \%$ of the value of the land-use right. This is broadly consistent with an estimate covering 17 provinces which showed that the amount going to farmers was $2.2 \%$ of the money received by the government after it improved the land and sold it for commercial use (Landesa and Renmin University, 2012), even though official data showed that half of the proceeds of land sales were paid as compensation. 
The impact of the very strict restrictions on the conversion of agricultural land to building land can be seen when comparing the edges of Beijing with Greater London, where prices are equivalent to CNY 5700 per $^{2}$ (Valuation Office Agency, 2011). Indeed, in rapidly growing areas in the London metropolitan area, the land zoned for residential use is worth 800 times neighbouring agricultural land and 600 times the value of the land before necessary infrastructure has been constructed. Compensation adequacy has to be judged against the current ownership status of the land. Farmers only own a 30-year use-right to cultivate the land and so legally cannot benefit from any change of use. However, they are clearly aware of the value of their land in alternative use and in a number of cities have taken illegal steps to attempt to secure the development value of the land for themselves (see below). In any case, such high differentials highlight the opportunity costs of not exploiting the land in its highest value use.

\section{Urban planning}

Local governments also influence urban development through the urban planning process. They must create 20-year master plans for the development of their areas and have them approved by the superior administrative authority. These master plans are essentially very broad-brush descriptions of how an area might develop, setting out objectives for transport, economic development and integration with the environment. A common problem faced by the designers of the master plan is that their planning cycle is far behind the speed of development of the local economy. This can be seen in the successive master plans for Beijing (Yang and Zhou, 2007) and Hangzhou (Wei, 2005), where targets for urban populations one decade in the future were exceeded within a few years. This problem is even apparent in the national $12^{\text {th }}$ Five-Year Plan, where the government set a target for an increase in the urbanisation rate of 0.8 percentage points per year, to reach $51.5 \%$ by 2015 . By 2012 , less than halfway through the plan period, the urbanisation rate had reached $52.6 \%$, with the expansion rate since 2010 being nearly $60 \%$ faster than envisaged under the Plan.

These master plans, however, do not regulate the use of individual pieces of land. That is decided at the lower level of the plot plan and often in isolation from other plots or after negotiation with developers (Bertaud, 2007). Thus within a city there is often no systematic consideration of how dense development should be in different parts of the city, in contrast to the approach in New York or Hong Kong where plot ratios are determined as a function of the attractiveness of the land with building density rising as the distance to the centre of the city diminishes.

\section{Development of collectively-owned land}

While the planning procedure for state-owned land in metropolitan areas is complicated, procedures for developing collective land are much simpler and have enabled villagers to capture a significant part of development rent. Collectively-owned land is split into three parts: residential, reserved and agricultural. For residential land, each household of the collective is allowed one plot of land of between 150 and $250 \mathrm{~m}^{2}$, depending on the region, to construct their own house. In practice, when the village collective is close to a densely populated area, or surrounded by such an area, the villagers have often become property developers. This is also common when the agricultural land of a village has been expropriated leaving just the collective owning the residential land. In some areas, to avoid dissent amongst the villagers, the urban authority has compensated the village with a certain proportion of the expropriated land - up to $12 \%$ in a number of fast-expanding southern cities (Hsing, 2010). In these areas village collective land was transferred to a company owned either by the collective or by the villagers. The company then develops the land and pays dividends to the owners. In other cases, the individual villagers develop their own site usually ignoring limitations on property height. In the absence of the usual planning regulations, users of land are often affected by externalities generated by neighbouring sites (Zhu and $\mathrm{Hu}, 2009$ ). 
Despite the illegality of the construction on rural land, this development has provided much of the rental housing for migrants and a low-cost ownership route for many residents with a local urban hukou. In Beijing, new, but illegal, property development (known as xiangchanquan housing), built by township governments on collective land classed as agricultural, accounted for $18 \%$ of all new property developments on the market in 2006 (Hsing, 2010). Generally, these properties sell for less than half the price of an equivalent property on state land, even though the two are often indistinguishable from developments on state land (Cao, 2007). The lower price reflects the legal risk attached to owning the property (Ye and $\mathrm{Wu}, 2010)$. Purchasers are willing to take the risk, despite the regular warnings from the authorities on the need for buyers to ensure that they have legal title to property, especially where the development is relatively large.

Indeed, little is done to enforce such warnings nationwide, though the risk for residents varies across areas. Demolition and confiscation are common in Beijing and Shanghai, but less so in Chengdu and Chongqing. Nanjing recently granted full property rights to one community after it dealt with the proper land transfer procedures (Chen, 2012). It is not clear that there is a legal deterrent as the urban authority has no jurisdiction in collectively-owned areas. In fact, in 2004 the Shanghai Higher People's Court ruled that while it was illegal for such housing units to be transferred to people with no residence rights in the community, if the property had actually been transferred to them and they were living there, then the status quo should be respected.

The risk of expropriation is greater for older property as some cities have a policy of acquiring older properties to redevelop the site. As a result, in central areas housing units on collective land have a much shorter life than similar housing on state land. One study found that village property was demolished after 12.7 years, ten years before property on nearby state land (Nie, 2012). Many southern cities have issued redevelopment plans for urban villages. These plans have often not been put into practice, however, as, with population densities of 200000 per $\mathrm{km}^{2}$, the only politically feasible solution is to negotiate with the village property company rather than expropriate. In such cases, the existing value of the site has been found to be sufficiently high that redevelopment is not financially viable. Overall, new property development on collective land has accounted for 8\% of urban development between 1995 and 2010 (Wu, 2012). Since most of this property is rented by migrants and other new entrants to the labour market, who accept space one third that of official residents, the share of the population in major cities housed, illegally, on collective land is probably as high as $25 \%$, rising to $70 \%$ in parts of Guangdong province.

The development of collective land by farmers, while providing housing for migrants, does have drawbacks. According to law, the zoning and urban planning of village collective land is the responsibility of the township government which governs the villages. However, the villages have the right to convert agricultural land to non-agricultural use as long as it is for their own use. Thus there is a legal ambiguity in how land can be developed. Village collectives resist the application of zoning by the township government and development often follows a haphazard pattern decided by competition between villages to develop land before it is expropriated (Zhu, 2012). This usually results in a lack of public facilities but has the advantage of providing lower-cost housing. Proximity to village land can also lower the value of nearby urban land and housing. Thus there is a need for a solution which provides for more of an overall development plan for village property while maintaining the right of villages to develop land.

One method that allows a degree of control over development has been the formation of village co-operatives which then decide a development plan and deal with nearby urban governments and realestate developers. This allows village collectives to keep a much higher proportion of the increase in value flowing from redevelopment. Experiments along these lines in the Beijing area have considerably calmed disputes about land (Po, 2011). 
Reforms are under way to improve the position of farmers whose land-use right is expropriated. In late 2012, the State Council authorised the Shenzhen government to pay farmers half of the increase in value of the land when it is converted to non-agricultural use. Furthermore, a national plan was announced in early 2013 to create a complete property register of all rural land in order secure property rights of farmers and give them legal proof for compensation in cases of land transfers. The law is to be changed to give a greater share to farmers of the appreciation in land values following expropriation. However, rural land on which construction has been authorised will not be allowed to be freely bought and sold. Furthermore, the current 30-year term of rural use-rights may be extended.

\section{Migration and urban growth}

\section{Migrants have been essential to urban growth}

Migration has driven around $70 \%$ of the growth in the urban population (Table 8 ) over the 40 years to 2010 but is difficult to measure accurately. Without migration the population of cities would probably barely have increased due to the one-child family planning policy, which has limited the natural growth of the urban population to around $0.6 \%$ per year. There are two types of migration in China: official and unofficial. In the former people change both their place of residence and the place in which they are enrolled for the household registration system. In the other type of migration, people change their residence but are not allowed by the government to change the locality where they are enrolled. Different agencies publish different data for the total number of unofficial migrants. The census estimated the unofficial migrant population to be 261 million in 2010 but does not include local migration. This number, though, includes migrants from one urban area to another. In 2005, such migrants were about half of the total number of migrants (OECD, 2010a). Such migration does not change the overall urban population. There is also an annual survey of the number of rural migrants who hold an agricultural hukou. It distinguishes both local and longer-distance migration but the figures have only recently been placed in the public domain. Overall, this survey suggests that the number of long-distance migrants and their non-working family members was 185 million in 2010, broadly consistent with the number shown in the census. In addition, there were nearly 90 million local migrants, bringing the total number of rural migrants to 275 million in 2010.

Table 8. Sources of growth of the urban population

\begin{tabular}{|c|c|c|c|c|c|}
\hline & $1970-80$ & $1980-90$ & $1990-2000$ & $2000-10$ & $1970-2010$ \\
\hline & \multicolumn{4}{|c|}{ average annual change per period, millions } & $\begin{array}{c}\text { Total } \\
\text { change }\end{array}$ \\
\hline $\begin{array}{l}\text { Change in urban population } \\
\text { of which }\end{array}$ & 4.7 & 11.1 & 15.7 & 20.7 & 521.4 \\
\hline 1) Natural increase of registered population & 1.3 & 1.5 & 1.8 & 2.1 & 66.4 \\
\hline 2) Migration & 2.9 & 9.5 & 9.2 & 15.8 & 374.0 \\
\hline Official migration from rural to urban areas & 2.0 & 1.8 & 3.0 & 3.0 & 98.0 \\
\hline Unofficial migration & 0.9 & 7.7 & 6.2 & 12.8 & 276.0 \\
\hline Local & 0.6 & 4.5 & 2.4 & 1.4 & 89.0 \\
\hline Longer distance & 0.0 & 2.1 & 3.0 & 10.0 & 151.0 \\
\hline Families of migrant workers & 0.0 & 0.9 & 0.7 & 1.5 & 31.0 \\
\hline Less urban-rural and rural-rural migration & 0.3 & 0.2 & 0.1 & -0.1 & 5.0 \\
\hline \multirow[t]{2}{*}{ 3) Areas that became urban (residual) } & 0.6 & 0.1 & 4.7 & 2.8 & 8.1 \\
\hline & \multicolumn{5}{|c|}{ Share of increase in population (in \%) } \\
\hline Natural growth & 26.8 & 13.4 & 11.4 & 10.2 & 12.7 \\
\hline Migration & 61.4 & 85.9 & 58.6 & 76.5 & 71.7 \\
\hline Expansion of urban area & 11.7 & 0.7 & 30.0 & 13.3 & 15.5 \\
\hline
\end{tabular}

Source: Unofficial migrants: Private communication from Lu Feng, as presented in Lu (2011) citing China Agricultural Yearbook 2010, Urban population: China Statistical Yearbook. 
The drivers of urban population growth have varied with the regulations governing population movement. Before the first liberalisation in the early $1980 \mathrm{~s}$, only official migration was allowed. In the early 1980s, migrants had to provide food from the countryside for themselves if they moved to an urban area: they were not eligible for the food rations allocated to local residents. As a result, nearly threequarters of migration was to local towns where it was possible for migrants to assure their own food supply. The only urban areas exempted from this rule were those designated as Special Economic Zones, which were experimenting with more liberal economic regulations. It was not until the decade ending in 2010 that large-scale migration across administrative borders occurred following liberalisation of regulations: local migration dropped sharply and longer-distance migration surged. There has also been a substantial flow of official migrants, which has been relatively stable, though in recent years a number of cities have tried to attract skilled or wealthy migrants using point-based hukous. Hardly any rural migrants have been able to benefit from this policy change.

Migration was temporarily held back by the financial crisis that erupted in August 2007 (Table 9). The number of areas that previously absorbed large number of migrants (such as the Pearl River Delta) fell. The stock of within-township migrants even declined in 2009, suggesting that longer-distance migrants may be more reluctant to move back to their farms than shorter-distance migrants when the demand for labour falls. In 2010-11, the flow of migrants quickly picked up as the economy improved, moving above the ten-year average, especially for local migrants.

Table 9. Recent developments in rural migration

\begin{tabular}{|c|c|c|c|c|c|}
\hline & 2000 & 2008 & 2009 & 2010 & 2011 \\
\hline & \multicolumn{5}{|c|}{ Millions } \\
\hline Stock of people having migrated outside their registered township & 94.5 & 169.0 & 175.0 & 184.1 & 191.4 \\
\hline Workers & 78.5 & 140.4 & 145.3 & 153.4 & 158.6 \\
\hline Family & n.a & 28.6 & 29.7 & 30.7 & 32.8 \\
\hline Total stock of workers who have migrated & 149.7 & 225.4 & 229.8 & 242.2 & 252.8 \\
\hline \multirow[t]{2}{*}{ Total stock of people who have migrated } & n.a & 254.0 & 259.4 & 272.9 & 285.6 \\
\hline & \multicolumn{5}{|c|}{$\%$} \\
\hline As $\%$ of total non-farm employment & 41.5 & 49.4 & 49.0 & 50.3 & 51.2 \\
\hline \multirow[t]{2}{*}{ Total migrants as $\%$ of urban population } & 20.6 & 27.1 & 27.1 & 27.5 & 27.7 \\
\hline & \multicolumn{5}{|c|}{ Millions per year } \\
\hline Flow of migrants (net) & n.a. & 11.0 & 5.4 & 13.5 & 12.6 \\
\hline Inside township & n.a. & 1.4 & -0.6 & 4.4 & 5.3 \\
\hline Outside township & n.a. & 9.6 & 6.0 & 9.1 & 7.4 \\
\hline
\end{tabular}

\section{Urban growth has helped narrow rural-urban income differentials}

As noted, migrants have moved to higher-income urban areas, which have gained further from agglomeration economies as their size has expanded. In the process, per capita income levels in the poorer areas have also risen as workers leave small farms with little if any reduction in output. There are also spillovers from the higher level of activity in the rich areas, on top of migrants' remittances to relatives in the rural areas. As incomes rise, property prices increase in the rich areas and land-intensive and transportintensive activities will tend to move to outlying areas. To some extent urban districts in China have attempted to internalise this movement by expanding their boundaries well into the countryside. Nonetheless, in the past decade the countryside around big cities has benefited from all of these changes. A further factor has allowed incomes in rural areas to benefit from urbanisation, namely the extensive investments undertaken in rail and road infrastructure. In the case of rail, this has taken the form of markedly increasing the footprint of the network by creating new radial lines from the main prefectural cities - a development that has still to be completed fully in the south-west of the country. In addition the provincial and prefectural road network has been improved. Railway communication has made it easier for manufacturing to relocate and better highways have reduced public transport times for migrants living in cities relatively close to their homes. 
These changes have helped reduce income differentials between cities and the countryside, as measured by GDP per capita (Table 10) and have improved the living standards of families one of whose members has migrated (De Brauw and Giles, 2012). Moreover, GDP per capita differentials are probably lower than the official estimate of urban-rural income differentials (Box 2).

Table 10. GDP per capita in cities and the countryside

For the 160 prefectures with a dense core city with a population of over 30000

\begin{tabular}{|c|c|c|c|c|}
\hline \multirow{4}{*}{$\begin{array}{l}\text { Ratio of urban districts to: } \\
\text { All counties in same prefecture }\end{array}$} & \multicolumn{4}{|c|}{$\begin{array}{l}\text { GDP per capita in urban districts/GDP per capita in selected } \\
\text { areas }\end{array}$} \\
\hline & 2000 & 2010 & 2000 & 2010 \\
\hline & \multicolumn{2}{|c|}{ weighted average } & \multicolumn{2}{|c|}{ unweighted averaged } \\
\hline & 2.9 & 2.4 & 4.3 & 2.3 \\
\hline All less dense counties in same prefecture & 3.1 & 2.7 & 2.5 & 2.4 \\
\hline All more dense counties in same prefecture & 2.7 & 2.2 & 2.7 & 2.3 \\
\hline
\end{tabular}
Source: OECD calculations.

\section{Box 2. The urban-rural income differential in China appears to be overstated}

The urban and rural surveys of household income are probably overstating the ratio of urban to rural income, possibly by as much as over $40 \%$ (Xu and Gao, 2012). The deficiencies in the household surveys are known to the National Bureau of Statistics, which is to launch a new national household survey in 2013.

The problems with the existing surveys stem from the rapid change in the labour market and the consequent migration of people from the countryside to the city. Given that migrants in China, as in many developing countries, keep close links with their family in their birth place, it can be difficult to allocate the income and consumption of a migrant worker.

The protocol for the surveys indicates that when migrants working in an urban area are an economically inseparable part of a rural household, their income should be counted as part of that household's income. In practice, this means that the income of a household where both spouse and children live in an urban area should be counted in the urban household survey, while other migrants should be included in the rural household survey.

However, a survey in two provinces (Zhejiang and Shaanxi) indicates complete migrant families represented around $30 \%$ of urban households in Zhejiang and $7 \%$ in Shaanxi, while nationwide they accounted for less than $1 \%$ of households in the urban household survey. So there are many missing households in the urban survey and this group is not counted in the rural household survey either.

For the rural household survey there is also another measurement problem linked to migrants. Rural households are supposed to report the complete income of urban migrants where a spouse or children still live in the rural area. In addition all unmarried adult children who are urban migrants should be counted in the rural survey. In reality, according to interviews with a sample of people included in the rural survey, rural households only report the income that the migrant sends back to the household. Detailed interviews showed that the remitted share of income for migrants where there was a spouse or child in the rural household was $70 \%$, but only $40 \%$ for unmarried children. This latter group represented the largest group of migrants whose income should have been fully counted in the rural survey, accounting for $80 \%$ of the total in Zhejiang and $40 \%$ in Shaanxi. Insofar as the two provinces under consideration are representative of nationwide patterns, this information on its own would suggest that the urban-rural income differential was 2.2 in 2009 and not 3.1 as shown in the official data. However, to the extent that underreporting of income is more of a problem for urban than for rural households, especially at higher income levels, the overstatement of the urbanrural gap would be less pronounced (Wang and Woo, 2010). 


\section{Providing public services to the families of migrants in cities}

\section{The scale of the problem}

Most of the migrants to major cities do not bring their families with them. Data from earlier censuses suggest that there were 11 million migrant children of compulsory education age in 2000 living without one of more of their parents, while in 2005 around 30 million children of the same age range were in the same position. If the number of such children has risen in proportion to the number of migrants, then by 2010 there were about 17 million migrant children in cities and 36 million left-behind children, a total of 53 million children representing about one-third of the total number of children in primary and junior high school. There may have been a more-than-proportionate rise in the number of migrant children in cities (and hence less left at home), as in Beijing the number of school-age migrant children quadrupled between 2000 and 2008 to reach 400000 (Rozelle et al., 2009). The type of education that these children receive will have a considerable impact on their ability to progress socially and economically.

\section{Progress in providing compulsory education}

The provision of free compulsory education to migrant children has much improved over the past decade. The main concerns now are about quality and the scale of the payment made by local authorities to the private schools educating many migrant children. Since 2003, the central government has actively encouraged local authorities to ensure that migrant children receive education in their place of residence at least to the age of 15 , when compulsory education finishes. It appears that nearly all migrant children now receive compulsory education at primary school level. At junior high school level, drop-out rates seem to have increased but the overall participation in nine-year education appears to be well over $90 \%$. As far as the left-behind children are concerned, they are educated in state schools in their place of residence. According to official figures $79 \%$ of migrant children are now educated in state schools, but it is not clear whether this covers all the children of migrants or just those who accompanied their parents.

The situation varies considerably across regions (Table 11) and from city to city. In Shanghai, all migrant schools in the centre of the city have been closed and children transferred to state schools. Further out of the city, children attend migrant schools funded by different levels of local government (Chen and Feng, 2012). Overall, $70 \%$ of migrant children attend state schools in Shanghai. However, the participation rate of migrant children in elite primary schools is probably lower as entry to these schools is dominated by parents in professional occupations and officials ( $\mathrm{Wu}, 2009)$. These schools, formerly known as "key schools", received extra funding, better teachers and were expected to guide other schools. The system of key primary schools has been abolished in Shanghai and elsewhere (OECD, 2010c) but the best quality primary schools actually continue to set entrance examinations (Yiwen, 2012).

Table 11. Type of school attended by migrant children

\begin{tabular}{lccc}
\hline & \multicolumn{3}{c}{ Type of school } \\
\hline \multirow{2}{*}{ Region } & Key schools & Public schools & Private schools \\
\cline { 2 - 4 } & \multicolumn{3}{c}{ \% of all migrant children } \\
\cline { 2 - 4 } East & 6.3 & 70.3 & 23.5 \\
Middle & 6.9 & 63.6 & 29.5 \\
West & 12.9 & 84.5 & 2.6 \\
Source: Li (2008). & &
\end{tabular}


In Shenzhen and Beijing, however, the situation is reversed and only $30 \%$ of migrant children attend state schools. In Shenzhen, the amount the local government spends per child on migrant schools is less than in state schools, implying much larger class sizes and less qualified teachers. In Beijing, policies towards migrants vary. Many migrant schools there are located on collectively-owned land. When either the urban district government expropriates the land, or the village collective redevelops it, migrant schools in that area are closed. Thirty such schools were demolished in 2012 in the Chaoyang, Shijingshan, Changping, Daxing, and Fengtai districts of Beijing (areas where migrants were $44 \%$ of the total population in 2010) with no provision for transferring the children to state schools (Beijing News, 2011). As a result, many children had to return to live with their grandparents (Li, 2012).

\section{But quality differences remain}

A major concern endures as to the quality of education. The results of migrant children, even when they attend state schools, appear to be worse than those of local children. The district education authorities do not administer standardised tests to children in migrant schools as they are considered outside the system. A private survey by Shanghai University of Finance and Economics has undertaken such tests across a sample of nine-year olds (Chen and Feng, 2012). The results show that the teachers in state schools are much better qualified than those in migrant schools. The performance of migrant children in migrant schools for Chinese tests is almost one standard error lower than for local children in state schools (Table 12). For mathematics, the score is $1 \frac{1 / 4}{4}$ standard deviations lower. In PISA test terms, this would put migrant schools in Shanghai on a par with the average results of schools in Chile, Mexico and Turkey. Once control variables were allowed for, the performance gap narrowed but was still significant. Similar results have been found for Beijing (Lai et al., 2012), where the performance of children at migrant schools, allowing for the impact of control variables, was even slightly worse than the performance of children in rural schools.

Table 12. Migrant and State schools in Shanghai compared



Source: Chen and Feng (2012). 


\section{High school education: under the same blue sky?}

Access to senior secondary school has improved much less than access to compulsory education. To attend high school it is necessary to take an entrance examination and this must be taken in the locality of registration rather than the locality of residence. In Shanghai, migrant children can only attend vocational high schools. The Shanghai Education Committee justifies local high schools' refusal to admit the children of migrant workers on the grounds that "if we were to open the door to them, it would be difficult to shut it in the future; local education resources should not be freely allocated to immigrant children" (Ren, 2012). As a result, few migrant children attend general high schools and those who do return to their registration locality find it hard to adapt and often fail to complete the course (Ming, forthcoming).

Migrant parents, and all low-income households, urban and rural, face a major financial barrier to send their children to senior secondary schools. Fees are high. In Shaanxi for instance, a three-year course costs the equivalent of $89 \%$ of the average annual net income of a rural household (Liu et al., 2009) - three times higher relative to income than in Indonesia and 60\% higher than in Mexico. These fee levels affect rural high school attendance (which is most probably only half that of urban registered children) and tend to lower performance in junior high school. Fees may also represent a barrier to achieving the government's target of raising the enrolment rate for senior high school to $90 \%$ by 2020 . Low educational achievement will undermine the employment prospects of future migrants, all the more so as China progressively becomes a more capital/innovation driven economy.

The need to return to the place of registration is compounded by the regulation that only allows a university entrance examination to be sat in the place of registration rather than the place of residence. In 2012, the Ministry of Education issued a new regulation encouraging provincial governments to allow pupils who are not registered locally to take the examination in the place of residence provided that the parent of the student has a stable job and pays social security contributions. However, the employers of most migrants do not enrol their employees in the social security programme, despite the provisions of the Labour law. Moreover, the Minister of Education has stated that local authorities can adapt the rules to take into account local conditions. This is meant to avoid people moving to a province with better quality universities (such as Beijing or Shanghai) to take the university entrance there so as to benefit from the fact that the acceptance mark for local universities is lower for locally registered students than for those with out-of-town residence. Fujian province, however, has announced that it will allow all migrant children who have been at junior or senior high school to take the entrance exam in Fujian. The Education Commission of this province sees this relaxation of rules as a way to attract more migrant workers to their province given current shortages of migrant labour.

For university entrance, the discrimination against students with registration outside the local district is severe. For example, in the past five years, $97 \%$ of the country's poorest counties sent no students to Beijing's prestigious Tsinghua University. In 2011, Peking University enrolled a third of its students from Beijing but less than one student in every 10000 came from Henan, Shandong or Hubei. In Shanghai, students with a local hukou are 53 times more likely than the national average to get a place at the city's prestigious Fudan University. The same entrance marks need to be applied to all pupils from across the country. 


\section{Access to health care for the families of migrants}

Apart from the persisting problems in education, migrant families also are unable to join the local health insurance scheme for children. Health insurance for employees is provided by the government if the employer joins the social security system, but many do not as penalties for non-compliance are low (OECD, 2010a). Moreover, the scheme covers only employees, not their children. To fill this gap a contributory (but subsidised) scheme has been introduced. But households registered outside the locality cannot join the local scheme and must join the scheme where they are registered, often with lower benefits which cannot be drawn outside the local area. The result is that the health of migrant children is markedly worse than that of local children (Table 13). It is not clear though whether these illness rates are better or worse than those in rural areas.

Table 13. Death rate of children under five in Guangdong Province

\begin{tabular}{|c|c|c|c|c|c|}
\hline \multirow[t]{3}{*}{ Classification } & \multicolumn{2}{|c|}{ Infant } & \multicolumn{2}{|c|}{$1-4$ years old } & \multirow{2}{*}{$\begin{array}{c}\text { Ratio of } \\
\text { migrant to } \\
\text { local deaths }\end{array}$} \\
\hline & Migrant & Local & Migrant & Local & \\
\hline & \multicolumn{4}{|c|}{ Deaths per 100000} & \\
\hline Malnutrition & 10.4 & 0.0 & 5.2 & 0.0 & $\infty$ \\
\hline Traffic accident & 5.2 & 0.0 & 41.7 & 2.9 & 16.3 \\
\hline Diarrhoea & 36.5 & 2.9 & 18.2 & 1.4 & 12.7 \\
\hline Diseases of the digestive system & 39.1 & 4.3 & 18.2 & 1.4 & 10.0 \\
\hline Septicaemia & 26.1 & 1.4 & 13.0 & 4.3 & 6.8 \\
\hline Injury and poisoning & 59.9 & 16.7 & 125.1 & 11.5 & 6.6 \\
\hline Infectious and parasitic diseases & 31.3 & 2.9 & 15.6 & 4.3 & 6.5 \\
\hline Meningitis & 10.4 & 4.3 & 13.0 & 0.0 & 5.4 \\
\hline Maternal factor in child birth & 783.7 & 148.8 & & & 5.3 \\
\hline Diseases of the respiratory system & 93.8 & 44.6 & 18.2 & 15.8 & 1.9 \\
\hline Diseases of the circulatory system & 13.0 & 10.1 & 10.4 & 4.3 & 1.6 \\
\hline Congenital malformations & 130.3 & 90.6 & 2.6 & 10.1 & 1.3 \\
\hline Neoplasm & 13.0 & 4.3 & 2.6 & 14.4 & 0.8 \\
\hline All above & 1263.1 & 330.9 & 289.2 & 70.5 & 3.9 \\
\hline
\end{tabular}

Source: Li et al. (2006) quoted in Chan (2009).

Furthermore, migrants generally cannot take advantage of the affordable housing programme. As a rule, only locally-registered people are allowed to purchase housing at a $30-40 \%$ discount through the economical housing programme, while the public rental programme is often unattractive given the rental levels and the poor locations where the property is built. There are also a number of administrative documents that require local registration: a driver's licence for example or a ticket in the lottery for car licence plates in Beijing.

\section{Financing of improved benefits}

The financing of compulsory education is shared between national governments and (in cities) the district-level government. On average, the national government pays for just over half of the cost of this level of education, but the share varies across regions (see Wang and Herd, 2013). While most transfer payments from central to local government are made in proportion to the registered population, the grant for compulsory education is made in proportion to the number of children at both state schools and schools for migrants. As more migrants settle in cities, the cost of education increases by the amount that wages of teachers in destination areas exceed wages in source areas. Moreover, there may be some need to build new schools. 
Turning to pension benefits, if employers were forced to enrol all migrant workers in pension schemes, costs would rise due to the redistributive character of the employee pension system. Over the lifetime of a migrant, the extra cost is estimated at CNY 80000 per person (Development Research Centre, 2011). Depending on the rate of discount that is used in the calculation this is equivalent to an extra public expenditure of around 1\% of GDP per year. Half of this cost represents extra pension expenditure that would occur some 40 years into the future. Since 2009, the pension system for migrant workers has been reformed. The employers' contribution has been reduced to $12 \%$ from $20 \%$ for this type of worker. At the same time, a portability provision has been introduced for people who move form province to province.

\section{Reform of the hukou system}

The objectives of the government in increasing urbanisation are to boost incomes, create domestic demand, rebalance the economy and create a stable urban society. To achieve these goals, hukou reform has been seen as a necessary step. Hukou reform is a complex issue, as registration status determines not only the rights of a person in their new urban location but also their rights in the place of origin. At present changing hukou status from agricultural to non-agricultural involves surrendering land-use rights in the place of origin and also may result in the loss of permission to have a second child. Thus the issues are far wider than giving rural migrants access to certain public services in urban areas. Full hukou reform would require changing the rules governing land-use ownership rights in the countryside and family planning regulations, as well as rights in urban areas. In response to central government pressure, most provinces now have regulations in place that allow people to transfer their household registration from one locality to another and from agricultural to non-agricultural status.

The changes that local governments have put in place set a high hurdle that migrants have to cross. By now, most provinces have begun to allow people without local registration to obtain registration or to merge local rural and urban registrations, but these changes have had limited effects. More than half of the provinces have merged their local rural and urban hukous, but not generally on a province-wide basis. Such changes have little impact on migrants as they come from outside local areas. In addition, most cities have reformed the rules for migrants to obtain a local hukou. In most provinces the scale of the reforms varies with city size (Table 14). For small and medium-sized cities, the qualifications to change residence status focus on employment stability and having appropriate housing (Table 15). In large cities the most common requirement is for a university education, though poorer provinces only insist on the person having at least a vocational high school certificate (Table 16). In addition, many provinces have a residence or tax payment requirement. As a result, in most of the attractive areas, reforms have had little impact. Even in smaller cities it can be difficult for migrants to meet the conditions as the employers of migrants often avoid affiliating their employees to social security systems and so paying taxation. 
Table 14. Extent of hukou reform by province

\begin{tabular}{|c|c|c|c|c|}
\hline & $\begin{array}{l}\text { Year of the } \\
\text { most } \\
\text { recent } \\
\text { reform }\end{array}$ & $\begin{array}{l}\text { Scope of application for } \\
\text { hukou by size of locality }\end{array}$ & $\begin{array}{c}\text { Unified } \\
\text { registration } \\
\text { between local } \\
\text { urban and local } \\
\text { rural hukou } \\
\end{array}$ & $\begin{array}{l}\text { Type of } \\
\text { province }\end{array}$ \\
\hline Anhui & 2001 & Large, medium, small (town) & No & Central \\
\hline Beijing & 2002 & Small (town) & No & Municipality \\
\hline Chongqing & 2003 & Large, medium, small (town) & Yes & Municipality \\
\hline Fujian & 2001 & Large, medium, small (town) & Yes & Eastern \\
\hline Gansu & 2003 & Large, medium, small (town) & No & Western \\
\hline Guangdong & 2001 & Large, medium, small (town) & Yes & Eastern \\
\hline Guizhou & 1998 & Small (town) & No & Western \\
\hline Hebei & 2003 & Large, medium, small (town) & Yes & Eastern \\
\hline Heilongjiang & 2008 & Medium city & Yes & Central \\
\hline Henna & 2003 & Large, medium, small (town) & Yes & Central \\
\hline Hubei & 2003 & Large, medium, small (town) & Yes & Central \\
\hline Hunan & 2003 & Large, medium, small (town) & Yes & Central \\
\hline Inner Mongolia & 2000 & Small (town) & No & Western \\
\hline Jiangsu & 2002 & Large, medium, small (town) & Yes & Eastern \\
\hline Jiangxi & 2002 & Large, medium, small (town) & No & Central \\
\hline Jilin & 2001 & Large, medium, small (town) & No & Central \\
\hline Liaoning & 2002 & Large, medium, small (town) & No & Eastern \\
\hline Ningxia & 1998 & Small (town) & No & Western \\
\hline Shandong & 2004 & Large, medium, small (town) & Yes & Eastern \\
\hline Shanghai & 2009 & Large & No & Municipality \\
\hline Shaanxi & 2005 & Large, medium, small (town) & Yes & Western \\
\hline Shanxi & 2007 & Small (town) & Yes & Central \\
\hline Sichuan & 2002 & Medium and small & Yes & Western \\
\hline Tibet & 2001 & Large, medium, small (town) & No & Western \\
\hline Xinjiang & 1998 & Small (town) & No & Western \\
\hline Yunnan & 2008 & Large, medium, small (town) & Yes & Western \\
\hline Zhejiang & 2002 & Large, medium, small (town) & Yes & Eastern \\
\hline
\end{tabular}

Source: Du (2011). 
Table 15. Small and medium-sized cities: criteria for obtaining local urban hukou

\begin{tabular}{|c|c|c|c|}
\hline & Stable source of income & Residence & $\begin{array}{c}\text { Years of } \\
\text { residence }\end{array}$ \\
\hline \multicolumn{4}{|l|}{ Municipalities } \\
\hline Chongqing & Any employment & Ownership/Employer & NA \\
\hline Beijing & Any employment & Not dormitory & Not specified \\
\hline \multicolumn{4}{|l|}{ Eastern } \\
\hline Hebei & Any employment & Not dormitory & No limit \\
\hline Liaoning & Any employment & Any form & Not specified \\
\hline Jiangsu & Any employment & Any form & 2 \\
\hline Zhejiang & Any employment & Any form & Not specified \\
\hline Fujian & Any employment & Any form & Not specified \\
\hline Shandong & Not specified & Any form & Not specified \\
\hline Guangdong & Any employment & Any form & Not specified \\
\hline \multicolumn{4}{|c|}{ Central provinces } \\
\hline Shanxi & Any employment & Ownership & Not specified \\
\hline Jilin & Any employment & Not dormitory & Not specified \\
\hline Heilongjiang & Contract or business & Not dormitory & 4 \\
\hline Anhui & Any employment & Not dormitory & 3 \\
\hline Jiangxi & Any employment & Any form & Not specified \\
\hline Henan & Contract or business & Ownership/Employer & Not specified \\
\hline Hunan & Any employment & Any form & Not specified \\
\hline Hubei & Any employment & Any form & Not specified \\
\hline \multicolumn{4}{|l|}{ Western } \\
\hline Inner Mongolia & Any employment & Any form & Not specified \\
\hline Sichuan & Any employment & Ownership/Employer & Not specified \\
\hline Guizhou & Any employment & Any form & 4 \\
\hline Yunnan & Any employment & Ownership/Employer & Not specified \\
\hline Tibet & Any employment & Any form & No requirement \\
\hline Shaanxi & Not specified & Any form & Not specified \\
\hline Gansu & Any employment & Any form & Not specified \\
\hline Ningxia & Any employment & Any form & 2 \\
\hline Xinjiang & Contract or business & Any form & 2 \\
\hline
\end{tabular}

Source: Du (2011). 
Table 16. Large cities: criteria for obtaining a local urban hukou

\begin{tabular}{|c|c|c|c|c|}
\hline & $\begin{array}{l}\text { Purchase of } \\
\text { housing }\end{array}$ & Private investment & $\begin{array}{l}\text { Tax payment to local } \\
\text { government }\end{array}$ & Education level \\
\hline Anhui & Minimum area & Not specified & Not specified & College \\
\hline Beijing & Not specified & Not specified & Not specified & Not specified \\
\hline Chongqing & Minimum area & Not specified & Not specified & College \\
\hline Fujian & No minimum & Decided by cities & Not specified & College \\
\hline Gansu & No minimum & Not specified & Not specified & Vocational high school \\
\hline Guangdong & Decided by cities & Decided by cities & Not specified & College \\
\hline Guizhou & No minimum & Not specified & Not specified & Not specified \\
\hline Hebei & No minimum & Not specified & Not specified & College \\
\hline Heilongjiang & Not specified & Not specified & Not specified & Not specified \\
\hline Henan & No minimum & Not specified & Not specified & Vocational high school \\
\hline Hubei & No minimum & Not specified & Size required & College \\
\hline Hunan & No minimum & Not specified & Not specified & Not specified \\
\hline Inner Mongolia & Not specified & Not specified & Not specified & Not specified \\
\hline Jiangsu & No minimum & Not specified & Not specified & College \\
\hline Jiangxi & No minimum & Decided by cities & Decided by cities & Vocational high school \\
\hline Jilin & No minimum & Not specified & Not specified & College \\
\hline Liaoning & No minimum & Not specified & Not specified & College \\
\hline Ningxia & No minimum & Not specified & Not specified & Not specified \\
\hline Shandong & No minimum & Investment required & Amount and years requirec & College \\
\hline Shanghai & Not specified & Not specified & Amount and years requirec & College \\
\hline Shaanxi & Minimum area & Not specified & Not specified & Vocational high school \\
\hline Shanxi & Minimum area & Not specified & 30000 yuan & College \\
\hline Sichuan & No minimum & Not specified & Not specified & Vocational high school \\
\hline Tibet & No minimum & 100000 yuan & Not specified & Vocational high school \\
\hline Xinjiang & No minimum & Not specified & Not specified & Not specified \\
\hline Yunnan & No minimum & Not specified & Not specified & Not specified \\
\hline Zhejiang & No minimum & Decided by cities & Decided by cities & Decided by cities \\
\hline
\end{tabular}

Source: Du (2011).

A number of provinces and cities introduced reforms in 2010. Chengdu and Chongqing reformed the hukou system as it applied to locals but not to migrants, while Guangdong established a new system for migrants. In both cases, the objective was to abolish the difference between the local agricultural and nonagricultural hukou. In Chongqing, the local government aimed to change the status of 3 million people by 2012 and 10 million by 2020. The first stage was to abolish the distinction between rural and nonagricultural hukous in each locality. Then people would be allowed to change their place of registration to a city area if they met a similar group of criteria as used in many other provinces (stable employment, owning an apartment). In both Chongqing and Chengdu, part of the system was based on exchanging rural land rights for urban status. In the case of Chongqing, the idea was to free up land near cities and then replace the agricultural land so lost by offering rural people an urban hukou in exchange for their residential land. Their house would be demolished and the land turned back into agricultural land. In this way, the Chongqing government would be able to extend its urban land without breaking the limit on conversion of agricultural land to urban land. This part of the reforms has now been stopped as the State Council issued a decision that land rights can no longer be exchanged for an urban hukou. The rules for granting a non-agricultural hukou in Guangdong are based on a points system that favours highly qualified people who are unlikely to be rural migrants (Table 17). 
ECO/WKP(2013)82

Table 17. The point system for acquiring an urban hukou in Guangdong

\begin{tabular}{lr}
\hline Number of points required & 65 \\
Guangzhou & 60 \\
Rest of the province & 80 \\
Points awarded & 5 \\
University graduate & 20 \\
Junior high school & 5 \\
High school & 2 \\
One year social security contributions & 2 \\
Charitable contribution per thousand yuan & 2 \\
Blood donation & 10 \\
Voluntary youth service (per 50 hours) & 60 \\
County-level honorary title & 10 \\
Prefectural-level honorary title & 30 \\
Junior professional employment & 50 \\
Mid-level worker & 60 \\
Senior worker & \\
Technician & \\
\hline
\end{tabular}

Source: Guangdong Provincial Government (2010).

Rural migrants are increasingly likely to want to remain in cities but few appear motivated to convert their rural hukou to an urban hukou. One well-known example of the low perceived value of urban hukou in smaller cities is that of Shijiazhuan (capital of Hebei province): in 2001, the local government announced major changes to the hukou system which, it stated, would mean that any person who had worked there for two years would be eligible for a local hukou. However, of the 300000 eligible persons, only 75000 changed their registration status (Zhan, 2011). An official survey found that almost three quarters of younger migrants had no desire to do so, though this proportion was lower in bigger cities (National Bureau of Statistics, 2011). This is perhaps because giving up a rural hukou often involves losing a land right. Migration was still seen as a circular process in which people stay in the city for a period and then return nearer to their home. However, very few migrants wish to return to be farmers; most want to move to a county seat or a town near their village (Zhu and Chen, 2010).

Even if the perceived value of sacrificing land holdings were not high, the requirements for obtaining a local hukou under the reforms that have been introduced would be difficult for a migrant to satisfy. The criteria to be met in order to obtain a new hukou pertain to education, wealth, stable employment and payment of taxes. There is no data on the number of people nationwide who have successfully made changes by fulfilling these criteria. Anecdotal evidence suggests that in the main, those who have changed are well educated and well off and often have a non-agricultural hukou from another city.

Migration has been seen more as way to maximise household income and lower risk than as a permanent decision. Moreover, settling in a city seems to be driven more by identity than by legal status (Zheng et al., 2009). Changing hukou status is not the key as to whether a person stays in a city or not. Rather the attributes of the person (education and willingness to invest in training) determine the length of time a person stays in a city. The attitude of the new generation of migrants, born between 1980 and 1990 , is changing. They have a much weaker attachment to the land. Their physiology, lifestyle and behaviour have become urbanised, and their employment is no longer an additional income for the families but their lifetime career. They do not know how to farm nor do they want to (China Development Reform Foundation, 2013). 


\section{What reform path for hukou?}

A fundamental difficulty with hukou reform is the right to both rural agricultural and residential land given by a rural hukou. This right is seen by most migrants as a valuable hedge against the uncertainty associated with earning labour income in cities. Moreover, most migrants still do not seek to settle permanently in one area: if job prospects change, they are prepared to move elsewhere. At the moment, even if the new generation of migrants (born in the 1980s) express a greater desire to stay in cities, most still envisage eventual return, if only on retirement. In this context, the hukou reforms introduced so far are mainly designed for highly-educated people moving from one city to another. The appropriate way forward would be to reduce the value of the urban hukou by disconnecting the eligibility for urban public services from the hukou status. For example the local authority could grant a residence permit giving the same rights to all people who have lived in an area for six months as to those holding a local urban hukou. The cost of such a policy to local authorities is rapidly declining as education is now provided for nearly all migrant children.

In 2011, the prefecture of Suzhou, one of the areas with the highest GDP per capita in the country, initiated a new residence permit policy along these lines. It announced that residence permits would replace temporary residence permits for migrant workers. Any migrant worker aged above 16, with a place to live and a stable living condition, can apply for a residence permit free of charge. The residence permit gives the same rights to migrants as permanent residents. These rights include health care for dependents on payment of a premium, education, employment, driving license application, employment security, transportation discounts, access to low-rent housing and other public services. By mid-2012, the prefecture had distributed 6.1 million residence permits by July 2012. As a result, the new residence permit policy now covers almost the entire migrant population.

Reform of the hukou system is a necessary step in the creation of an inclusive urban society. The most pressing aspect of reform is to allow all residents in urban areas equal access to local services. Such a reform can be achieved without a full reform of all of the laws that are linked to hukou status. The reforms undertaken in Suzhou appear to be a promising route as they enable urban rights to be equalised without the need to change the rights of the migrants in rural areas which requires significant administrative and legal action.

\section{Will migration and urbanisation boost domestic demand and rebalance the economy?}

There is international evidence to suggest that urbanisation by itself results in a rebalancing of the economy, through a decrease of household or national saving (Loayza et al., 2000; Hung and Qian, 2010). Usually it is hypothesised that this is because urban income is more secure than rural income and so urban residents save less for precautionary reasons. The magnitude of the impact is small and uncertain. If the urbanisation rate were to rise from $50 \%$ to $65 \%$ (as is plausible for China over the next one or two decades), then the national saving rate might be expected to drop by only 0.8 percentage points from its 2010 level of over $50 \%$. Moreover, panel regressions fail to explain a high proportion of the Chinese saving rate (Hung and Qian, 2010).

One reason for the failure of panel regressions to explain the level of urban saving may be that the employment situation of migrant workers is not very stable and their social benefits are low relative to urban residents. In the Chinese context, it is possible that at least until a large portion of the migrant population has decided that it is preferable to remain in the city, the saving rate may rise as urbanisation proceeds. Household surveys show the saving rate of migrant households to be extremely high - well above that of local residents and above that of rural households. A number of studies have found that migrants save more than urban households. Chen et al. (2012) found the level of consumption of migrant families was 37\% lower than for local households. In Guangdong, one study found a saving rate of $60 \%$ (Huang, 2010). Amongst migrants living in urban villages in Beijing, the saving rate was estimated at $47 \%$ (Zheng et al., 2009). 
It is difficult to rationalise such high saving rates in terms of high levels of insecurity or poor social services - the counter-factual is that the migrant remains in the countryside where health and social security benefits are even worse and saving rates lower. The high saving rate may partly reflect transfers to families remaining in the countryside. However, Brugiavini et al. (2013) find that even in migrant households with two people present (and hence reduced need for transfers to the countryside) the saving rate is still higher than for urban households. They attribute this to habit persistence on the part of those who move from lower-income areas and suggest that this differential will disappear if migrants stay in cities. As well, self-selection may be one reason why migrants save: they have decided to seek higher incomes at considerable risk. In any case, although each individual has limited consumption ability and does not consume much, the sheer number of rural migrant workers, and of their family members, represents an enormous potential for consumption expansion (China Development Reform Foundation, 2013).

Migrants' high saving rate may decline as they become more settled and as their incomes rise. Since 2009, there has been a turnaround: until then, the wages of migrants had been constantly declining relative to the wages of local workers; since 2009, they have been rising faster, reflecting the marked demographic change that has started to occur in the number of 20-year olds (Figure 13). Besides, migrants' consumption pattern is different: young migrants spend much more on housing and clothing than local residents (Figure 14). The money spent on housing though generally flows back to local "farmers" who are often the landlords.

Figure 13. Cohorts of 20-year olds

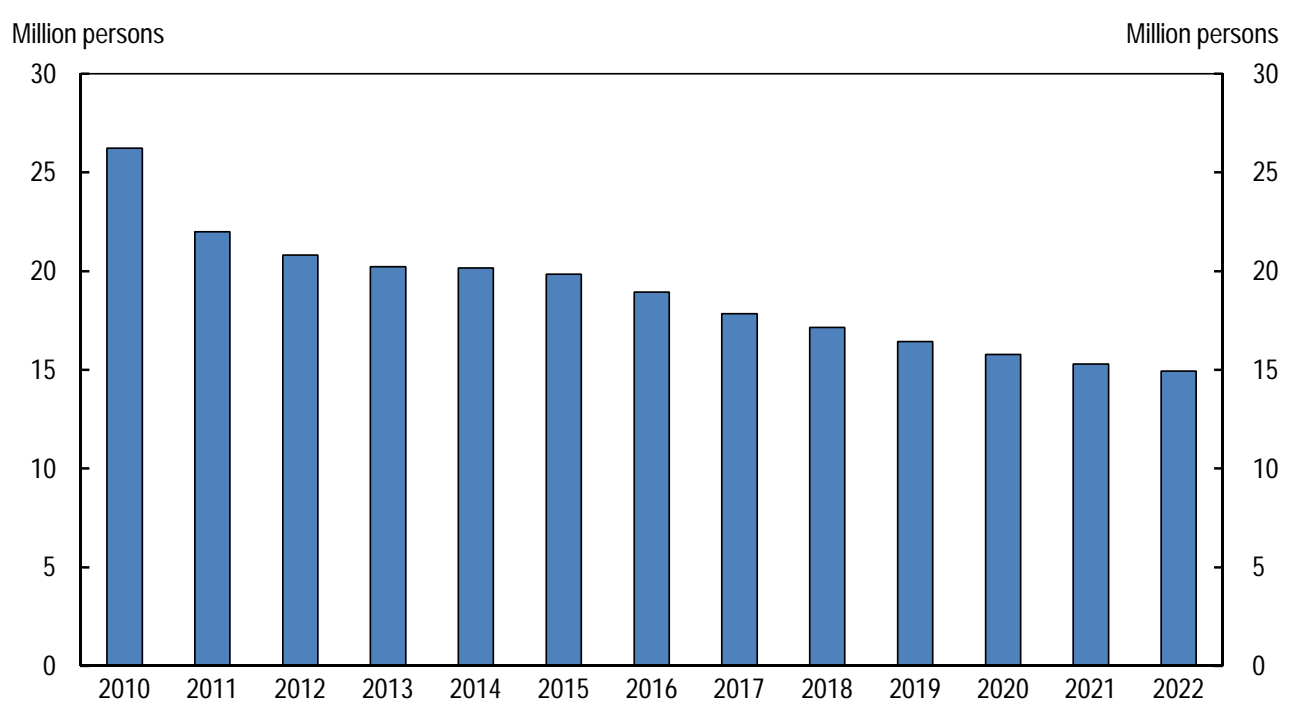

Source: US Bureau of the Census (2011). 
Figure 14. Consumption patterns of migrants and registered residents

In 2010
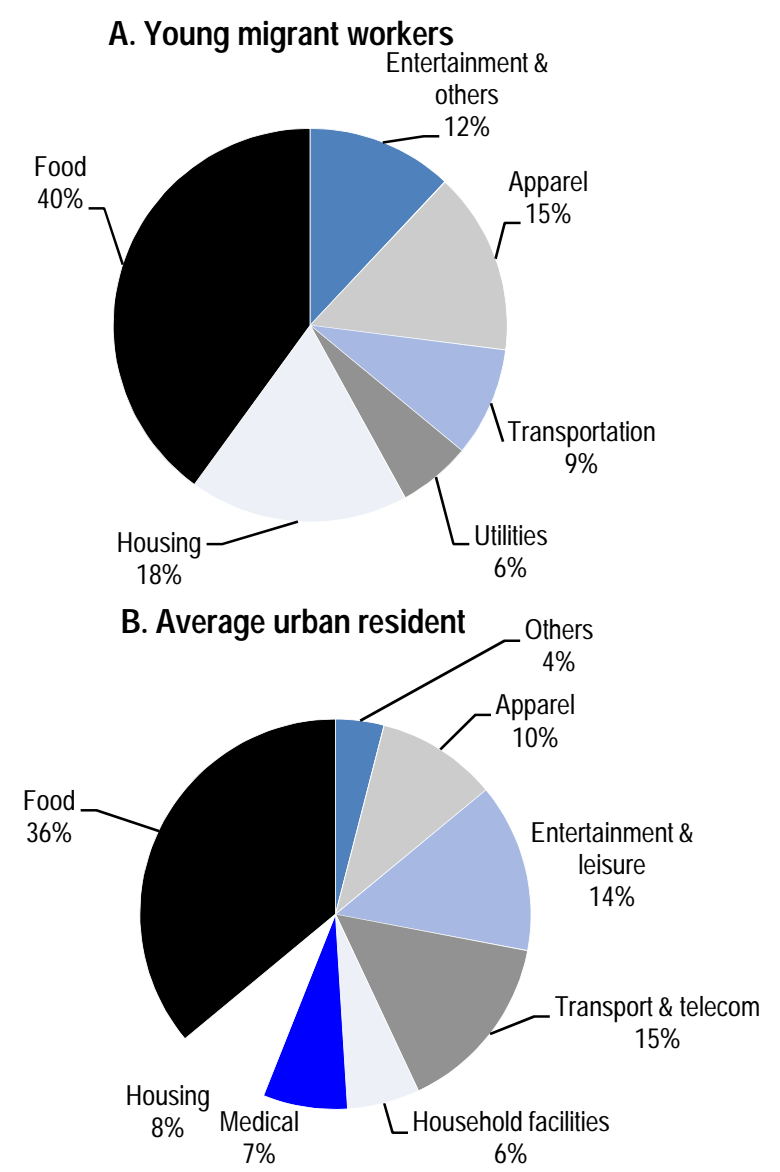

Source: National Population and Family Planning Commission (2011).

\section{Constraints on further urbanisation}

Government regulations concerning the conversion of agricultural land to construction land are very strict. The 1994 Basic Farmland Protection Regulation requires the designation of farmland protection districts at the township level and prohibits any conversion of land in those districts to other uses. It also requires that a quota of farmland preservation be determined first and then allocated to lower-level governments in the five-level administrative chain (state, province, city, county and township). The 1999 New Land Administration Law intends to protect agricultural land and coordinate the planning and development of urban land. It stipulates that the government should strictly implement overall plans and annual plans for land utilisation and take measures to ensure that the total amount of cultivated land within their administrative areas is not reduced. Moreover designated basic farmland shall not be less than $80 \%$ of total cultivated land. The designation of basic farmland is based primarily on soil productivity rather than location. Because existing urban development has occurred near historically high-productivity areas, that land is likely to be designated as basic farmland whereas land farther away is not. Such restrictions impose a high economic cost and, as shown above, force farmers to develop land within existing townships, creating a leapfrogging development pattern (Ding, 2004). 
Conversion of designated cropland into construction land is very difficult. It is only possible for key projects such as energy, transportation, irrigation and military infrastructure and then with the approval of the State Council. Other forms of land can be designated for future construction only through a provincial master land-use plan established once per decade and approved by the State Council. Provinces are allocated conversion quotas based on existing land-use shares. After the provincial land conversion quota has been established, the provincial government reserves some land for itself and then allocates the remainder to prefectural-level cities. First, it allocates conversion quotas for key transportation, irrigation, water-conservancy and energy generation projects. Secondly, the quotas for land to be used for normal transportation, irrigation, water conservancy and rural residential purposes are distributed to each city using the existing share of each land category in the prefecture as a weight. Finally, construction land conversion quotas for urban development are allocated to each city based on weights taking into account the existing land urban land area, the GDP of the city in secondary and tertiary sectors and the predicted city-level land needs (Wang, Tao and Tong, 2009). Each prefecture allocates conversion rights to lower levels of government. The national government also sets an annual land-use conversion quota and the amount used under this quota has to ensure that the designated agricultural land targets are not breached. As the master plan covers a whole decade, the government also sets a limit on the conversion that is possible within the plan period. Finally, a quota has been established for the creation of new agricultural land and this is also distributed down from the province to the prefecture. Such a method for the conversion of land is arbitrary and takes no account of economic factors. A much more market-based system is needed. The province of Zhejiang has introduced a market in conversion quotas so that the areas with surplus quotas can sell them to deficit areas, but this is only a second-best procedure.

The fundamental reason given for the quotas (national security) is mistaken. The government is concerned that, if the country were to face a military blockade or subject to an export embargo (as was the case for the Soviet Union in 1980), there would be food shortages. The authorities are also concerned that a continuing increase in Chinese food imports over the medium term would drive up world prices which would weigh on consumers given the still high share of food in household spending. Such concerns seem largely unjustified. Food supply is surprisingly elastic even in the short term. Crops can be changed and land brought back into cultivation within one year, and less where two crops are possible. The experience of Britain between 1939 and 1945 bears this out. In 1939, imports accounted for over half of demand for cereals and potatoes. As a sea blockade grew in importance, imports fell but in one year domestic production rose a quarter and in three years it had risen by three-quarters (Table 18). Over the three-year period, total demand for cereal and potatoes actually rose, though meat demand fell substantially. It is always possible that the type of substitution that occurred in Britain at the time might not be feasible in China. But in agriculture, national security would seem better served by adequate contingency planning for increased domestic production rather than by preventing an improvement in the living conditions of the population. 
Table 18. National security and food security: the example of Britain during the Second World War

\begin{tabular}{|c|c|c|c|c|}
\hline \multirow{3}{*}{ Year } & \multicolumn{4}{|c|}{ Supply and demand for cereal, animal feed, potatoes in Britain } \\
\hline & Import & Production & Demand & Import proportion \\
\hline & \multicolumn{3}{|c|}{ Thousands tons } & $\%$ \\
\hline 1939 & 10497 & 9758 & 20255 & 51.8 \\
\hline 1940 & 10225 & 12042 & 22267 & 45.9 \\
\hline 1941 & 7351 & 14413 & 21764 & 33.8 \\
\hline 1942 & 4127 & 16959 & 21086 & 19.6 \\
\hline 1943 & 4249 & 17978 & 22227 & 19.1 \\
\hline 1944 & 3833 & 16939 & 20772 & 18.5 \\
\hline 1945 & 4969 & 17320 & 22289 & 22.3 \\
\hline
\end{tabular}

Source: Weir (2009).

The future growth of urban areas is likely to put further pressure on this central-planning method of allocating land for new construction. Agricultural land has dropped substantially in the past decade. By 2008 (the last year for which data is available), agricultural land had fallen to within $1.1 \%$ of the government limit (Figure 15). Between 2010 and 2020, the urban population is likely to increase by over 200 million, if the recent pace of city growth continues with the urbanisation rate rising to above $60 \%$ (United Nations, 2012). In addition, rising disposable income will result in households demanding more living space. It is unlikely that migrant workers will be content to live in an area of $8 \mathrm{~m}^{2}$ per person if they choose to settle in urban areas. If the current average population density in built areas (of just under 10000 per $\mathrm{km}^{2}$ ) is maintained, average living space increases as in the past decade and the plot ratio remains constant, then the demand for building land will soon exceed the available supply, putting upward pressure on prices (Figure 16).

Figure 15. Agricultural land use and the government limit

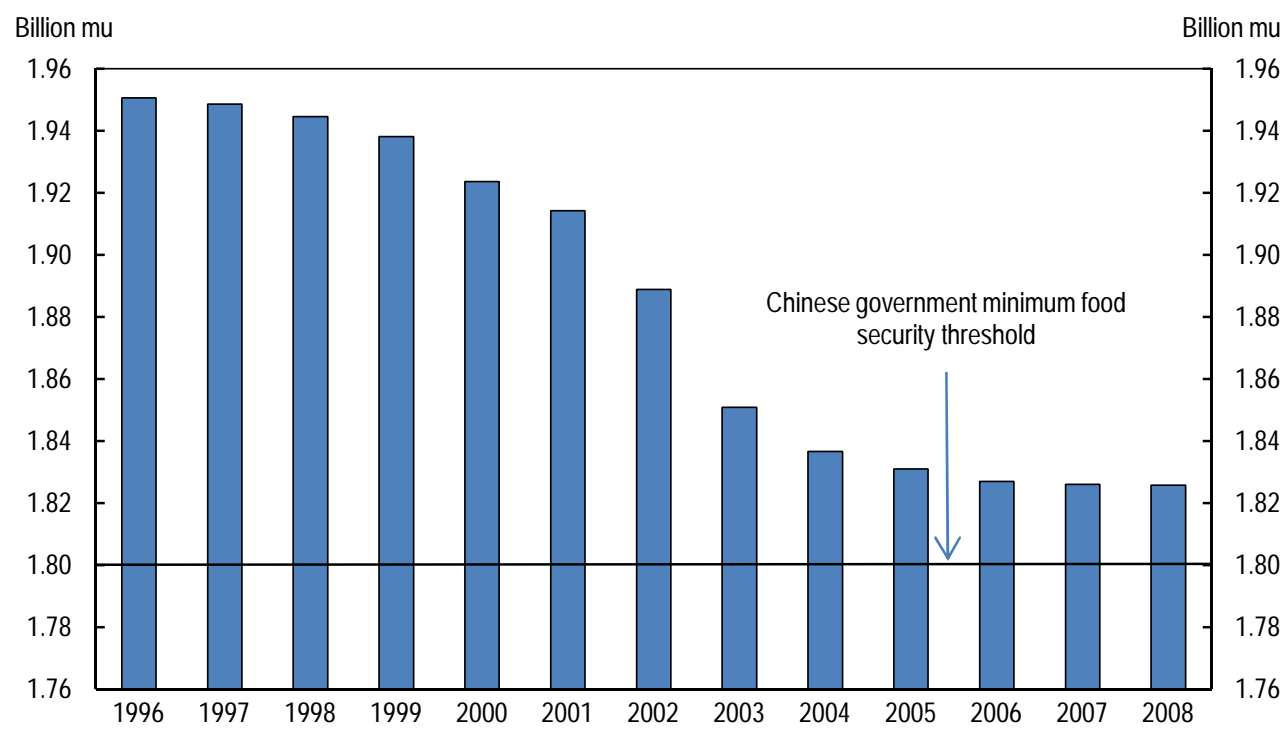

Source: Ministry of Land and Resources. 
Figure 16. Projected increase in built area from 2010 to 2020

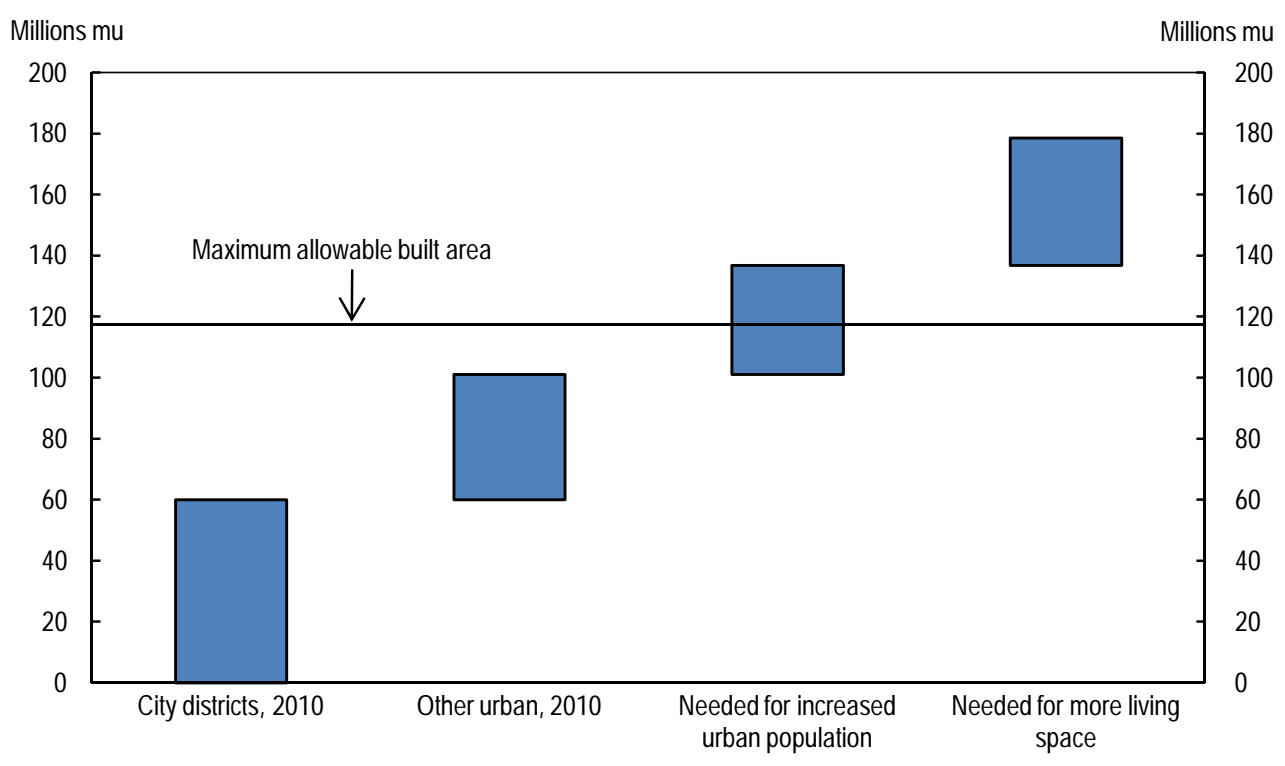

Source: OECD projections.

Pressure on land prices in the past decade has led local authorities to take land illegally and then to central government attempts to restrict such land grabs. Moreover, at the local level there has been pressure from farmers for greater, market-based compensation. Farmers are aware that in many areas village collectives have been able to keep a far greater share of the increase in value of land when it switched from agricultural to construction use. The response of the central government has been to centralise the land conversion process by establishing quotas that cascade down through the administrative hierarchy. In an economy that is now market-based in most areas, allocating building land by administrative fiat is an anomaly. Moreover, rural land remains essentially a non-marketable asset. A major change in land ownership rules in rural areas is needed to allow famers and their collectives to obtain land-use rights enabling them to change the use of their land to construction. Subjecting sales of land for building to valueadded tax would give local authorities a substantial income to replace the profit currently made on land development. Finally, decentralisation of the agricultural protection quotas is needed, as it is very unlikely that central government can judge the needs of each province and similarly that the provinces can judge the needs of each city. Governments might still need to be active in redevelopment, but a freer market in land would ensure a closer matching of supply and demand. In addition, replacing land development profits by a value-added tax on development gains and perhaps a property tax would bring greater transparency to local government finances.

\section{Conclusions}

Over the past decade, as labour mobility increased and the housing market opened up to private capital, China has undergone the world's most massive and rapid urbanisation. Population and value-added have risen most in very large cities, but not at the expense of rural areas, where productivity has risen with outmigration. More than 300 million people now live in cities were GDP per capita is on a par with incomes in some OECD member countries. However, the growth of cities has not been without problems. The inherited institutional structure means that as a rule, migrants cannot access all public services in the city where they live. Remaining artificial barriers between migrants and the local population need to be progressively reduced by delinking rights to access public services from the hukou system. This system is fundamental to the migrant's continued ownership of the use-right to land in the countryside. As cities 
expanded, the value of rural land has increased. Village collectives need to become full owners of their land with restrictions on development removed, so that villagers can sell or develop their land subject to the levy of an appropriate tax. A structured vision for city development is still needed, but the monopoly of land development by the government should be ended. In a number of instances, exclusive reliance on government planning has held back the pace of development, pushed up land prices and created large amounts of illegal construction. Equally, the centralised system of land development quotas needs to be ended. Urbanisation can also generate externalities such as congestion and pollution. These problems are not necessarily linked to city size, but can be dealt with by appropriate policies that internalise externalities and so enable cities to develop more efficiently.

\section{Box 3. Main policy recommendations}

\section{Urban planning and transport}

- Government policy towards city size should be neutral. Policies that favour small and medium-sized cities should be ended as should those that restrict the growth of large cities.

- The annual quota for the conversion of agricultural land should be abandoned as should the national floor on agricultural land. They should be replaced by a locally-determined master plan that takes into account the need to lower housing prices at the fringes of larger cities.

- In large cities, subway systems are generally still undersized, requiring further investment. In smaller cities, more emphasis should be given to Bus Rapid Transit systems.

\section{Land use}

- Plot ratios in urban master plans should take into account public transport availability and the nearness of public facilities, and the district plans should follow master plans more closely.

- The size of residential development sites should be lowered to increase value and allow more competition amongst developers.

- A much higher proportion of the development value of agricultural land should accrue to farmers. Greater legal certainty should be given to the property development undertaken on collectively-owned "village" land located in urban or peri-urban areas. The use of a company structure could help achieve this objective.

- The expenditures funded by land sales should be made more transparent, both as far as the cost of redevelopment is concerned and with respect to the final destination of compensation payments.

- The land-use rights of farmers should be extended to allow - subject to zoning and planning requirements the sale, renting and mortgaging of their rights which should be extended to 70 years in order to allow the development of larger farms.

\section{Public service provision to migrants}

- Disconnect the provision of local services from the possession of a local hukou.

- Increase the subsidies to private schools that provide education to migrant children. Allow migrants to enroll in high schools in their place of residence instead of their place of registration.

- Allow the university entrance examination to be taken in the place of residence.

- Abolish local quotas for entrance to university. 


\section{BIBLIOGRAPHY}

Anderson, G. and Y. Ge (2005), "The Size Distribution of Chinese Cities", Regional Science and Urban Economics, Vol. 35.

Au, C.-C. and V. Henderson (2006), “Are Chinese Cities Too Small?”, Review of Economic Studies, Vol. 73.

Banerjee, A., E. Duflo and N. Qian (2012), “On the Road: Access to Transportation Infrastructure and Economic Development”, NBER Working Papers, No. 17897.

Bao, H., J. Glascock and S. Zhou (2008), "Land Value Determination in an Emerging Market: Empirical Evidence from China", Department of Land Economy Working Paper, Cambridge.

Baum-Snow N., L. Brandt, J. Vernon-Henderson, M. Turner and Q. Zhang (2012), "Roads, Railways and Decentralization of Chinese Cities", Brown University Working Paper, Rhode Island.

Baum-Snow, N. and M. Turner (2012), "Transportation and the Decentralization of Chinese Cities", Brown University Working Paper, Rhode Island.

Beijing News (2011), “30 Migrant Schools Demolished”, 16 August.

Berkelmans, L. and H. Wang (2012), "Chinese Urban Residential Construction to 2040”, Reserve Bank of Australia Research Discussion Papers, No. 2012-04.

Bertaud, A. (2007), "Urbanisation in China: Land Use Efficiency Issues”, mimeo, www.alain-bertaud.com.

Brugiavini, A., G. Weber and B. Wu (2013), "Saving Rates of Urban Households in China", in Gomel, G., D. Marconi, I. Musu and B. Quintieri (eds), The Chinese Economy: Recent Trends and Policy Issues, Springer-Verlag, Berlin.

Cai, H., J. Vernon Henderson and Q. Zhang (2009), "China's Land Market Auctions: Evidence of Corruption?”, NBER Working Papers, No. 15067.

Cao, R. (2007), "Small Property Development in Wuhan", Wuhan Real Estate Network, http://wh.focus.cn/news/2007-07-05/332620.html (in Chinese).

Chan, A. (2009), "Paying the Price for Economic Development: The Children of Migrant Workers in China", China Labour Bulletin, Hong Kong.

Chang, S.D. (1963), “The Historical Trend of Chinese Urbanization", Annals of the Association of American Geographers, Vol. 53.

China Development Research Foundation (2013), China's New Urbanization Strategy, forthcoming, Routledge, London.

Chen, B., M. Lu and N. Zhong (2012), "Hukou and Consumption Heterogeneity: Migrants' Expenditure is Depressed by Institutional Constraints in Urban China", Fudan University School of Economics Working Paper, January.

Chen, D. (2012), “Cheap but Illegal”, Global Times, 9 March.

Chen, Y. and S. Feng (2012), "Access to Public Schools and the Education of Migrant Children in China", IZA Discussion Papers, No. 6853. 
De Brauw, A. and J. Giles (2012), "Migrant Labor Markets and the Welfare of Rural Households in the Developing World: Evidence from China", IZA Discussion Papers, No. 6765.

Development Research Centre (2011), A Study of Rural Migrant Workers, Beijing (in Chinese).

Demographia (2012), Demographia World Urban Areas (World Agglomerations), $8^{\text {th }}$ Annual Edition, Version 2, http://www.demographia.com/db-worldua.pdf.

Deng, L., Q. Shen and L. Wang (2009), "Housing Policy and Finance in China: A Literature Review", prepared for U.S. Department of Housing and Urban Development, Urban Planning Department University of Michigan and Real Estate Department of the Chongqing University.

Ding, C. (2004), "Farmland Preservation in China", Land Lines, Vol. 16.

Du Y. (2010), "An Assessment of Hukou Reform in Chongqing”, in Roberts et al. (2010), Urbanization Policy in Chongqing Municipality: A Framework Note, Department of Land Economy, University of Cambridge, July.

Fan, C. C. (1999), “The Vertical and Horizontal Expansion of China's City System”, Urban Geography, Vol. 20.

Glaeser, E. (2011), Triumph of the City: How Our Greatest Invention Makes Us Richer, Smarter, Greener, Healthier, and Happier, Macmillan, London.

Glaeser, E. L. and J. D. Gottlieb (2009), "The Wealth of Cities: Agglomeration Economies and Spatial Equilibrium in the United States", Journal of Economic Literature, Vol. 47.

Goldewijk, K., A. Beusen and P. Janssen (2010), "Long-Term Dynamic Modelling of Global Population and Built-Up Area in a Spatially Explicit Way", The Holocene, Vol. 20.

Guangdong Provincial Government (2010), Guidance Regarding the Point System for Converting Migrant Workers into Urban Hukou, Guangdong Provincial Government Official Document No. 32, (in Chinese).

Henderson, V. (1974), “Optimum City Size: The External Diseconomy Question”, Journal of Political Economy, Vol. 82.

Henderson, V. and H. Wang (2004), "Urbanization and City Growth", mimeo, Brown University.

He, C., Z. Huang, and W. Wang (2012), "Land Use Changes and Economic Growth in China", Land Lines, Lincoln institute of Land Policy, Cambridge, MA.

Hill, S. (2013), "Reforms for a Cleaner, Healthier Environment in China", OECD Economics Department Working Papers, No. 1045.

Holland, M. and P. Watkiss (2004), Benefits Table Database: Estimates of the Marginal External Costs of Air Pollution in Europe, Directorate General for the Environment, European Commission, Brussels.

Hsing, Y.-T. (2010), The Great Urban Transformation: Politics of Land and Property in China, Oxford University Press, Oxford.

Huang, Y. (2010), "Urbanization, Hukou System and Government Land Ownership: Effects on Rural Migrant Works and on Rural and Urban Hukou Residents", Background paper, OECD Development Centre. 
Hughes, C. and X. Zhu (2011), Guangzhou, China Bus Rapid Transit: Emissions Impact Analysis, Institute for Transport and Development Policy, New York.

Hung, J.H. and R. Qian (2010), "Why Is China's Saving Rate So High? A Comparative Study of CrossCountry Panel Data", Congressional Budget Office Working Paper, No. 2010-07.

Kamal-Chaoui, L., E. Leman and Z. Rufei (2009), "Urban Trends and Policy in China", OECD Regional Development Working Papers, 2009/1, OECD publishing.

Lai, F. , C. Liu, R. Luo, L. Zhang, X. Ma, Y. Bai, B. Sharbono and S. Rozelle (2012), "Private Migrant Schools or Rural/Urban Public Schools: Where Should China Educate Its Migrant Children?", Rural Education Action Project Working Paper, No. 224.

Landesa and Renmin University (2012), The 2011 Findings of the17-Province Survey of Rural Land Rights in China, Landesa Institute, Seattle and Beijing.

Li, R. (2008), "Migrant Education in China", Presentation to the OECD Migration Committee, National Centre for Education Development Research, Beijing.

Li, R. (2012), "Migrants' Children Learn of Education Inequality”, South China Morning Post, $6^{\text {th }}$ March.

Li, R., Q. Zhao, X. Zhong, Q. Deng and Q. He (2006), "Preventable Deaths of Children Below Five Years Old in Guangdong's Migrant Population”, International Medicine \& Health Leader, Vol. 12 (in Chinese), quoted in Chan (2009).

Liu, C., L. Zhang, R. Luo, S. Rozelle, B. Sharbono and Y. Shi (2009), "Development Challenges, Tuition Barriers, and High School Education in China", Asia Pacific Journal of Education, Vol. 29.

Loayza, N., K. Schmidt-Hebbel, and L. Servén (2000), "What Drives Private Saving across the World?", The Review of Economics and Statistics, Vol. 82.

Man, J.Y. (2011), “Affordable Housing in China”, Land Lines, Lincoln Institute of Land Policy.

Matsumoto, T. and D. Sanchez-Serra (2012), "How Compact City Policies Contribute to Urban Sustainability and Green Growth?", in Compact City Policies: a Comparative Assessment, OECD Publishing.

Ming, H. (forthcoming), The Education of Migrant Children and China's Future, Routledge, London.

Ministry of Finance (2012), Presentation of the 2012 Budget to the National Party Congress, Beijing.

National Bureau of Statistics (2011), "New Generation of Migrant Workers”, Department of Rural Social and Economic Survey, Beijing, March (in Chinese).

National Population and Family Planning Commission (2011), Report on Development of China's Migrant Population, Beijing (in Chinese).

Nakamura, K. and M. Tahira (2008), "Distribution of Population Density and the Cost of Local Public Services: The Case of Japanese Municipalities", Working Paper No. 231, Faculty of Economics, University of Toyama.

Nie, Z. (2012), “Will Incomplete Property Rights Distort Land Development? Evidence from Urban Villages in China", University of Hong Kong Working Paper.

OECD (2006), Competitive Cities in the Global Economy, OECD Publishing, Paris. 
OECD (2010a), Economic Survey of China, OECD Publishing, Paris.

OECD (2010b), Trends in Urbanisation and Urban Policies in OECD Countries: What Lessons for China, OECD and China Development Research Foundation.

OECD (2010c), Shanghai and Hong Kong: Two Distinct Examples of Education Reform in China, OECD Publishing, Paris.

OECD (2011), How's Life? Measuring Well-Being, OECD Publishing, Paris.

Pan, H. (2011), "Implementing Sustainable Urban Travel Policies in China”, Discussion Paper No. 2011/12 International Transport Forum, OECD Publishing.

Po, L. (2011), "Property Rights Reforms and Changing Grassroots Governance in China's Urban-Rural Peripheries: The Case of Changping District in Beijing", Urban Studies, Vol. 48.

Ren, D. (2012), “Government Mulls Opening City Schools to Migrant Children”, South China Morning Post, 25 August.

Rozelle, S., X. Ma, L. Zhang and C. Liu (2009), "Educating Beijing's Migrant Children: A Profile of the Weakest Link in China's Education System”, Working Paper No. 212, REAP, Stanford University.

Suzuki, H., D. Arish, S. Moffatand and N. Yabuki (2011), Eco ${ }^{2}$ Cities: Ecological Cities as Economic Cities, World Bank, 2011.

Trewartha, G.T. (1952), "Chinese Cities: Origins and Functions", Annals of the Association of American Geographers, Vol. 42.

United Nations (2012), World Urbanization Prospects: The 2011 Revision, Population Division, Department of Economic and Social Affairs, New York.

Valuation Office Agency (2011), Property Market Report 2011, London.

Wang, X. and R. Herd (2013), "The System of Revenue Sharing and Fiscal Transfers in China", OECD Economics Department Working Papers, No. 1030.

Wang, H., R. Tao and J. Tong (2009), "Trading Land Development Rights under a Planned Land Use System: The "Zhejiang Model" and Its National Implications", China and the World Economy, Vol. 17.

Wang, Y.P., Y. Wang and J. Wu (2009), "Urbanization and Informal Development in China: Urban Villages in Shenzhen", International Journal of Urban and Regional Research, Vol. 22.

Wang, X. and X. Xia (1999), "Promoting Economic Growth by Optimizing Urban Size", (In Chinese), Economic Research Journal, No. 9.Wang, H., R. Zhang, M. Liu and J. Bi (2012), "The Carbon Emissions of Chinese Cities", Journal of Atmospheric Chemistry and Physics, Vol. 12.

Wang, X. and T. Y. Woo (2010), "The Size and Distribution of Hidden Household Income in China", National Economic Research Institute, Beijing.

Wei, Y. D. (2005), "Planning of Chinese Cities: The Limits of Transitional Institutions", Urban Geography, Vol. 26.

World Bank (2012), Doing Business in a More Transparent World, Washington DC. 
Wu, X. (2009), "The Power of Market Mechanism in the School Choice in China: An Empirical Study", Presentation to the conference "Penser les marchés scolaires", Université de Genève - March.

Wu, Y. (2012), Small House Property Issues: The Status Quo and the Way Out, REICO Institute China Real Estate Chamber of Commerce, Beijing (in Chinese).

Xu, J. and W. Gao (2012), "How Large is the Urban-Rural Income Gap in China?", Presented to the International conference of the Research Centre for International Economics, Washington University, Korea Institute for Industrial Economics and Trade, and Asia-Pacific Economics Association, Seattle, March.

Yang, L., Q. Chen, G. Li, Y. Gao and X. Tao (2005), “Analysis of the Development of Land-Banking Organizations in China”, Economic Geography, Vol. 25 (in Chinese).

Yang, J. and J. Zhou (2007), “The Failure and Success of Greenbelt Program in Beijing”, Urban Forestry \& Urban Greening, Vol. 6.

Ye, J. and J.Wu (2010), "Peri-Urban Land Tenure", in J. M. Lubink, A. J. Hoekema, and W.I. Assie (eds), Legalising Land Rights: Local Practices, State Responses and Tenure Security, Leiden University Press.

Yiwen, L. (2012), "Fierce Competition to Get into Top Primary Schools", 9 May, People's Daily, http://english.peopledaily.com.cn/203691/7812468.html.

Zhaopin and Peking University Social Survey Centre, 2012 Annual Chinese Workplace Balance Index Research Report, Peking University Social Survey Research Centre, May.

Zheng, S., F. Long, C. Fan, and Y. Gu (2009), "Urban Villages in China: A 2008 Survey of Migrant Settlements in Beijing", Eurasian Geography and Economics, Vol. 50.

Zhan, S. (2011), "What Determines Migrant Workers' Life Chances in Contemporary China: Hukou, Social Exclusion, and the Market", Modern China, Vol. 37.

Zhang, J. (2011), "Inter-jurisdictional Competition for FDI: The Case of China's "Development Zone Fever", Regional Science and Urban Economics, Vol. 41.

Zou, Y. (2014), "Contradictions in China's Affordable Housing Policy: Goals vs. Structure”, Habitat International, Vol. 41.

Zhu, J. (2012), "Governance over Land Development During Rapid Urbanization under Institutional Uncertainty - With Reference to Peri-Urbanization in the Guangzhou Metropolitan Region", Institute of Real Estate Studies Working Papers, No. 2012-28, National University of Singapore.

Zhu, J. and T. Hu (2009), "Disordered Land-Rent Competition in China's Periurbanization: Case Study of Beiqijia Township, Beijing", Environment and Planning, Vol. 41.

Zhu, Y. and W. Chen (2010), "The Settlement Intention of China's Floating Population in the Cities: Recent Changes and Multifaceted Individual-Level Determinants", Population, Space and Place, Vol. 16. 


\title{
ANNEX A1. DEFINITION OF CITIES USED IN THIS PAPER
}

In China cities are defined through a hierarchical system of administrative units. The (descending) order of the cities is as follows:

\author{
Directly-controlled municipality \\ Special-plan city \\ Provincial capital \\ Prefectural-level city \\ County-level city
}

The lowest level of disaggregation considered in this paper is the county-level authority as economic and social statistics are gathered at this level.

The area covered by cities frequently extends well into the countryside surrounding the metropolitan core of the city. Indeed the administrative area of the city has often been extended to include areas that were previously counties.

Outside the directly-controlled municipalities, the national territory is split into areas covered by provincial capital and areas administered by provincial level cities. Each provincial level city is split into an area known as the city proper (shi), county-level cities and counties. The city proper is split into country-level areas known as districts $(q u)$.

These divisions do not follow from a demographic definition of a city or a metropolitan area. For example, many district areas have very low population densities and extend over large areas. On the other hand there are some counties that are very dense and have large populations but are nonetheless not classified as cities.

This paper uses a definition of a cities (or metropolitan areas) that is based on numerical rather than administrative criteria: here a city is defined as an area with a population of at least 300000 and where every county-level authority under the city administration has a population density of 500 people per $\mathrm{km}^{2}$, which is the lowest density of a metropolitan area in the United States.

In the case of Beijing, for example, this means that a number of districts and counties have been excluded from the definition of Beijing metropolitan area, on the grounds that while there may be concentrations of population in the excluded localities, their overall density was less than 500 people per $\mathrm{km}^{2}$. As Beijing's population has expanded, the population density of the outlying areas has grown. Consequently, the Beijing metropolitan area is shown here as increasing between 2000 and 2010, even though Beijing's administrative area has been unchanged.

It is thus important to bear in mind that the metropolitan areas as defined in this paper can have substantial rural population living in low-density areas. Similarly there are urban areas through out the country that are not included here as metropolitan areas.

Given the complicated nature of the classification of cities, many analysts chose to define cities as being grouped according to tiers. There is no common definition of how to make this ranking. Here metropolitan areas have been ranked by their average ranking in population and GDP. The top five cities in this ranking are called Tier 1 cities and the next 25 Tier 2 cities (Table A1.1). The next 70 cities are classified as Tier 3 cities (Table A1.2). The remaining 400 cities are split into Tier 4 and 5, for which only summary data are shown (Table A1.1). 
Selected socio-economic data for the five tiers of cities are shown in Table A1.2. The estimates of average GDP per capita for 2012 have been approximated assuming that the growth rate of GDP and population are the same for the metropolitan areas, as defined above, and the prefectural cities of which they are a part.

Table A1.1. Chinese metropolitan areas grouped by tiers: selected socio-economic data

\begin{tabular}{|c|c|c|c|c|c|c|c|c|}
\hline & \multirow[t]{2}{*}{ Year } & \multirow[t]{2}{*}{ Unit } & \multicolumn{5}{|c|}{ Ranking of city (metropolitan areas) } & \multirow[b]{2}{*}{ All cities } \\
\hline & & & Tier 1 & Tier 2 & Tier 3 & Tier 4 & Tier 5 & \\
\hline Number of cities & 2010 & & 5 & 25 & 70 & 200 & 200 & 500 \\
\hline Population & 2000 & Millions & 48.4 & 87.9 & 93.8 & 186.0 & 111.1 & 521.2 \\
\hline Population & 2010 & Millions & 71.2 & 117.3 & 115.4 & 194.0 & 113.2 & 604.7 \\
\hline Increase in population & $2000-2010$ & $\%$ & 47.0 & 33.5 & 23.0 & 4.3 & 1.9 & 16.0 \\
\hline Area & 2000 & $\mathrm{~km}^{2}$ & 19.6 & 51.9 & 89.0 & 247.2 & 160 & 561.1 \\
\hline Area & 2010 & $\mathrm{~km}^{2}$ & 24.4 & 57.8 & 94.1 & 247.8 & 161 & 576.9 \\
\hline Increase in area & $2000-2010$ & $\mathrm{~km}^{2}$ & 4.8 & 5.9 & 5.1 & 0.5 & 0.4 & 15.8 \\
\hline GDP & 2010 & Billion yuan & 5862 & 7717 & 6,082 & 6317 & 2720 & 28428 \\
\hline Average population in city & 2010 & Millions & 14.2 & 4.7 & 1.6 & 1.0 & 0.6 & 1.2 \\
\hline Average GDP per capita & 2010 & Yuan & 82382 & 65760 & 52,708 & 32560 & 24,027 & 47016 \\
\hline Average GDP per capita & 2010 & US Dollar & 12171 & 9715 & 7,787 & 4810 & 3550 & 6946 \\
\hline Average GDP per capita & 2010 & International dollar & 20777 & 16585 & 13,293 & 8212 & 6060 & 11858 \\
\hline Average GDP per capita & 2012 & International dollar & 25057 & 21233 & 17,174 & n.a. & n.a. & n.a. \\
\hline
\end{tabular}

Source: 2010 Census Tabulation, Economic and Statistical Communiqués of Prefectural Level Cities.

Note: An international dollar is the result of converting a value in the currency of a country by the PPP exchange rate for that country. 
Table A1.2. Tier 1 and 2 cities

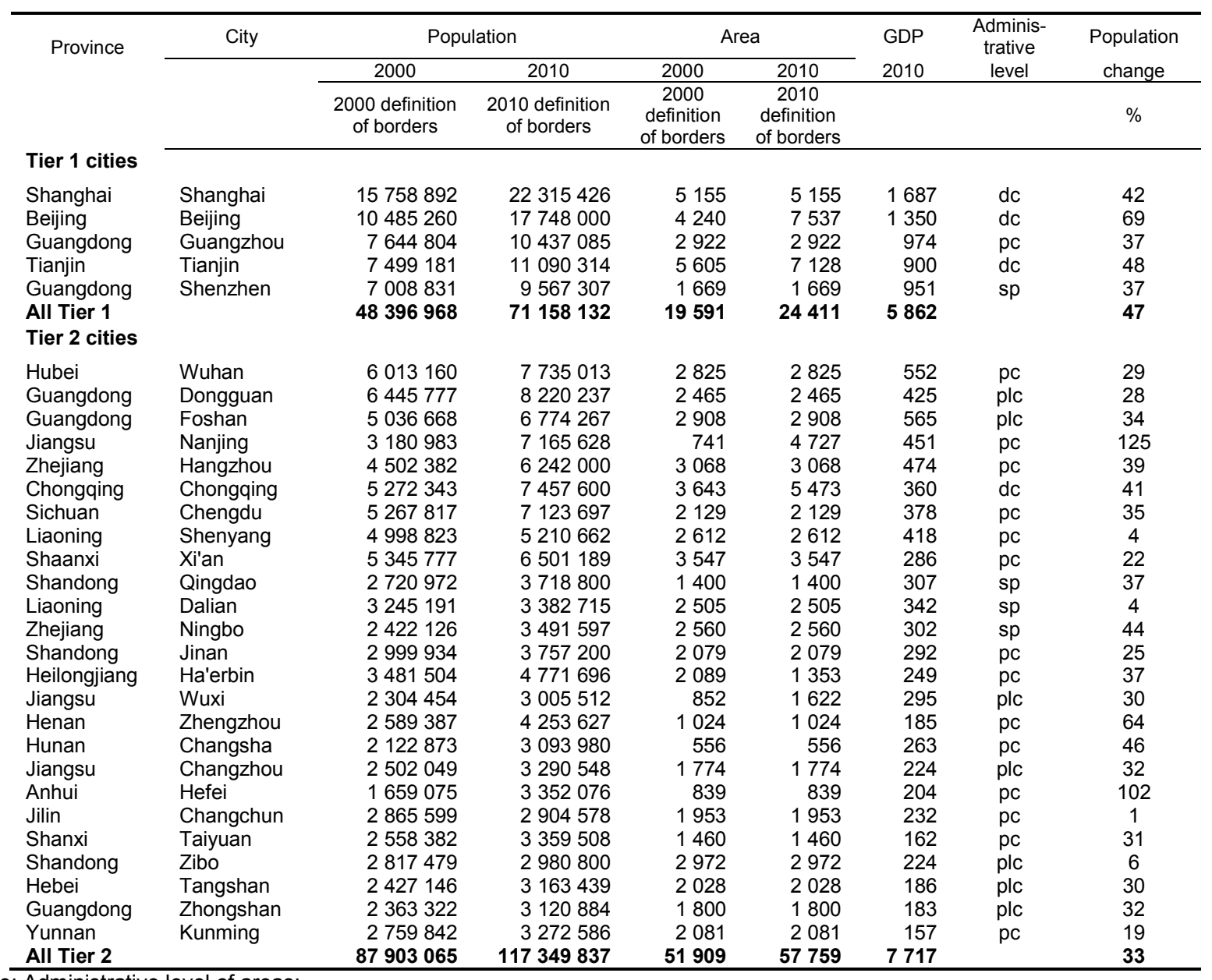

Note: Administrative level of areas:

$\begin{array}{ll}\text { dc } & \text { Directly controlled municipality } \\ \text { sp } & \text { Special-plan city } \\ \text { pc } & \text { Provincial capital } \\ \text { plc } & \text { Prefectural-level city } \\ \text { cc } & \text { County-level city } \\ \text { co } & \text { County }\end{array}$

Data for Chongqing refers only to the metropolitan area of Chongqing and not to the whole municipality.

Source: 2010 Census, but data for metropolitan areas in Liaoning and Jilin have been estimated on the basis of the growth of prefectural-level cities, as disaggregated data for these provinces were not available. 
ECO/WKP(2013)82

Table A1.3. Tier 3 cities

\begin{tabular}{|c|c|c|c|c|c|c|c|c|}
\hline \multirow[t]{3}{*}{ Province } & \multirow[t]{3}{*}{ City } & \multicolumn{2}{|c|}{ Population } & \multicolumn{2}{|l|}{ Area } & \multirow{2}{*}{$\begin{array}{l}\text { GDP } \\
2010 \\
\end{array}$} & \multirow{2}{*}{$\begin{array}{c}\text { administrative } \\
\text { level }\end{array}$} & \multirow{2}{*}{$\begin{array}{c}\text { Population } \\
\text { change }\end{array}$} \\
\hline & & 2000 & 2010 & 2000 & 2010 & & & \\
\hline & & $\begin{array}{c}2000 \\
\text { definition of } \\
\text { borders }\end{array}$ & $\begin{array}{c}2010 \\
\text { definition of } \\
\text { borders }\end{array}$ & $\begin{array}{c}2000 \\
\text { definition } \\
\text { of borders }\end{array}$ & \multicolumn{3}{|c|}{2010 definition of borders } & $\%$ \\
\hline Tier 3 cities & & & & & & & & \\
\hline Guangdong & Shantou Shi & 4046390 & 3772245 & 1226 & 1226 & 119 & plc & -7 \\
\hline Fujian & Xiamen Shi & 1369814 & 2297016 & 1142 & 1142 & 205 & $\mathrm{sp}$ & 68 \\
\hline Fujian & Fuzhou Shi & 2124435 & 2921763 & 1014 & 1014 & 151 & pc & 38 \\
\hline Zhejiang & Wenzhou Shi & 1915548 & 3039500 & 1188 & 1188 & 120 & plc & 59 \\
\hline Jiangxi & Nanchang Shi & 1779123 & 2293875 & 333 & 333 & 150 & $\mathrm{pc}$ & 29 \\
\hline Xinjiang & Wulumuqi (Urumqi) Shi & 1513541 & 2378308 & 828 & 1104 & 128 & pc & 57 \\
\hline Hebei & Shijiazhuang Shi & 1969975 & 2735976 & 455 & 455 & 115 & pc & 39 \\
\hline Guangxi & Nanning Shi & 1832244 & 2264683 & 2377 & 2741 & 123 & pc & 24 \\
\hline Jiangsu & Kunshan Shi & 750074 & 1646318 & 927 & 927 & 210 & $\mathrm{CC}$ & 119 \\
\hline Inner Mongolia & Huhehaote Shi & 961193 & 1980774 & 1088 & 2101 & 133 & pc & 106 \\
\hline Gansu & Lanzhou Shi & 1947030 & 2492325 & 1088 & 1088 & 95 & pc & 28 \\
\hline Shandong & Linyi Shi & 1938510 & 2600200 & 1759 & 1759 & 89 & plc & 34 \\
\hline Jiangsu & Suzhou Shi & 1344709 & 1526768 & 342 & 342 & 228 & plc & 14 \\
\hline Jiangsu & Jiangyin Shi & 1315472 & 1594829 & 988 & 988 & 200 & $\mathrm{Cc}$ & 21 \\
\hline Jiangsu & Xuzhou Shi & 1679626 & 1908524 & 1180 & 1180 & 115 & plc & 14 \\
\hline Jiangsu & Huai'an Shi & 2593915 & 2416719 & 3206 & 3206 & 83 & plc & -7 \\
\hline Guangdong & Huizhou Shi & 862822 & 1881563 & 1262 & 2672 & 112 & plc & 118 \\
\hline Fujian & Jinjiang Shi & 1479259 & 1986447 & 721 & 721 & 91 & $\mathrm{CC}$ & 34 \\
\hline Guizhou & Guiyang Shi & 1717474 & 2300185 & 478 & 478 & 82 & $\mathrm{pc}$ & 34 \\
\hline Zhejiang & Taizhou Shi & 607660 & 1902500 & 434 & 1538 & 87 & plc & 213 \\
\hline Guangdong & Zhuhai Shi & 1235437 & 1598171 & 1277 & 1277 & 120 & plc & 29 \\
\hline Liaoning & Anshan Shi & 1556285 & 1622237 & 622 & 622 & 114 & plc & 4 \\
\hline Jiangsu & Changshu Shi & 1239637 & 1510103 & 1263 & 1263 & 145 & $\mathrm{Cc}$ & 22 \\
\hline Guangdong & Jiangmen Shi & 1468742 & 1822640 & 1692 & 1692 & 86 & plc & 24 \\
\hline Henan & Luoyang Shi & 1491680 & 1932459 & 554 & 554 & 81 & plc & 30 \\
\hline Guangdong & Zhanjiang Shi & 1350665 & 1747231 & 1360 & 1360 & 77 & plc & 29 \\
\hline Fujian & Putian Shi & 1359558 & 1862421 & 992 & 2284 & 68 & plc & 37 \\
\hline Guangxi & Liuzhou Shi & 963662 & 1436599 & 667 & 667 & 86 & plc & 49 \\
\hline Hainan & Haikou Shi & 1508341 & 2046189 & 2237 & 2237 & 59 & pc & 36 \\
\hline Shandong & Zaozhuang Shi & 1552815 & 1570800 & 2047 & 2047 & 73 & plc & 1 \\
\hline Jiangsu & Zhangjiagang Shi & 957223 & 1248414 & 813 & 813 & 160 & $\mathrm{CC}$ & 30 \\
\hline Zhejiang & Cixi Shi & 1214537 & 1462383 & 1154 & 1154 & 76 & $\mathrm{CC}$ & 20 \\
\hline Shandong & Tengzhou Shi & 1548817 & 1603700 & 1485 & 1485 & 63 & $\mathrm{CC}$ & 4 \\
\hline
\end{tabular}


Table A1.3. Tier 3 cities (continued)

\begin{tabular}{|c|c|c|c|c|c|c|c|c|}
\hline \multirow[t]{3}{*}{ Province } & City & \multicolumn{2}{|c|}{ Population } & \multicolumn{2}{|c|}{ Area } & \multirow{2}{*}{$\begin{array}{l}\text { GDP } \\
2010\end{array}$} & \multirow{2}{*}{$\begin{array}{c}\text { Administrative } \\
\text { level }\end{array}$} & \multirow{2}{*}{$\begin{array}{c}\text { Population } \\
\text { change }\end{array}$} \\
\hline & & 2000 & 2010 & 2000 & 2010 & & & \\
\hline & & $\begin{array}{l}2000 \text { definition } \\
\text { of borders }\end{array}$ & $\begin{array}{l}2010 \text { definition } \\
\text { of borders }\end{array}$ & $\begin{array}{c}2000 \\
\text { definition } \\
\text { of borders }\end{array}$ & \multicolumn{2}{|c|}{$\begin{array}{l}2010 \text { definition of } \\
\text { borders }\end{array}$} & & $\%$ \\
\hline Jiangsu & Wujiang Shi & 857104 & 1275090 & 1192 & 1192 & 100 & $\mathrm{CC}$ & 49 \\
\hline Liaoning & Fushun Shi & 1434447 & 1495236 & 713 & 713 & 63 & plc & 4 \\
\hline Shandong & Tai'an Shi & 1538211 & 1735500 & 2087 & 2087 & 56 & plc & 13 \\
\hline Jiangsu & Yancheng Shi & 1534182 & 1615717 & 1729 & 1729 & 56 & plc & 5 \\
\hline Jiangsu & Yangzhou Shi & 1072496 & 1198866 & 148 & 986 & 95 & plc & 12 \\
\hline Jiangsu & Yixing Shi & 1164275 & 1235476 & 2039 & 2039 & 81 & $\mathrm{CC}$ & 6 \\
\hline Fujian & Quanzhou Shi & 1032215 & 1211238 & 510 & 510 & 81 & plc & 17 \\
\hline Zhejiang & Wenling Shi & 1162783 & 1366800 & 836 & 836 & 58 & $\mathrm{cc}$ & 18 \\
\hline Shandong & Xintai Shi & 1344395 & 1315900 & 1933 & 1933 & 59 & $\mathrm{cc}$ & -2 \\
\hline Henan & Nanyang Shi & 1584715 & 1811732 & 1887 & 1887 & 45 & plc & 14 \\
\hline Zhejiang & Huzhou Shi & 1145414 & 1293219 & 1588 & 1588 & 59 & plc & 13 \\
\hline Jilin & Jilin Shi & 1146298 & 1151347 & 1576 & 1576 & 97 & plc & 0 \\
\hline Shandong & Weifang Shi & 1024355 & 1194100 & 815 & 815 & 76 & plc & 17 \\
\hline Anhui & Huainan Shi & 1228189 & 1674334 & 1212 & 1526 & 43 & plc & 36 \\
\hline Shandong & Laiwu Shi & 1233525 & 1298500 & 2246 & 2246 & 55 & plc & 5 \\
\hline Zhejiang & Yiwu Shi & 912670 & 1234000 & 1103 & 1103 & 62 & $\mathrm{CC}$ & 35 \\
\hline Zhejiang & Yueqing Shi & 1162765 & 1389300 & 1174 & 1174 & 50 & $\mathrm{cc}$ & 19 \\
\hline Fujian & Nan'an Shi & 1385276 & 1418451 & 2035 & 2035 & 48 & $\mathrm{cc}$ & 2 \\
\hline Zhejiang & Rui'an Shi & 1207788 & 1424700 & 1278 & 1278 & 46 & $\mathrm{cc}$ & 18 \\
\hline Hubei & Xiangyang Shi & 1871146 & 1120885 & 2920 & 1259 & 81 & plc & -40 \\
\hline Guangdong & Maoming Shi & 644301 & 1217715 & 879 & 879 & 57 & plc & 89 \\
\hline Zhejiang & Jiaxing Shi & 881923 & 1201900 & 968 & 968 & 58 & plc & 36 \\
\hline Shanxi & Datong Shi & 998312 & 1223171 & 108 & 108 & 53 & plc & 23 \\
\hline Sichuan & Mianyang Shi & 1162962 & 1355331 & 1570 & 1570 & 45 & plc & 17 \\
\hline Zhejiang & Zhuji Shi & 1070675 & 1157900 & 2311 & 2311 & 62 & $\mathrm{cc}$ & 8 \\
\hline Shandong & Jimo Shi & 1111202 & 1177200 & 1780 & 1780 & 57 & $\mathrm{cc}$ & 6 \\
\hline Fujian & Fuqing Shi & 1174540 & 1234838 & 1932 & 1932 & 48 & $\mathrm{cc}$ & 5 \\
\hline Anhui & Wuhu Shi & 697197 & 1043876 & 720 & 444 & 79 & plc & 50 \\
\hline Jiangsu & Rugao Shi & 1362533 & 1267066 & 1531 & 1531 & 43 & $\mathrm{cc}$ & -7 \\
\hline Zhejiang & Shaoxing Xian & 791797 & 1030800 & 1196 & 1196 & 78 & $\mathrm{co}$ & 30 \\
\hline Jiangsu & Xinghua Shi & 1441659 & 1408711 & 2393 & 2393 & 39 & $\mathrm{cc}$ & -2 \\
\hline Hunan & Zhuzhou Shi & 879996 & 1055373 & 535 & 535 & 65 & plc & 20 \\
\hline Hebei & Baoding Shi & 902496 & 1099182 & 137 & 137 & 58 & plc & 22 \\
\hline Sichuan & Zigong Shi & 916687 & 1262062 & 1023 & 1431 & 42 & plc & 38 \\
\hline Jiangsu & Pizhou Shi & 1539922 & 1458036 & 2088 & 2088 & 37 & $\mathrm{cc}$ & -5 \\
\hline Henan & Luohe Shi & 1131007 & 1294891 & 1020 & 1020 & 40 & plc & 14 \\
\hline Guangdong & Zengcheng Shi & 899644 & 1036731 & 1616 & 1616 & 68 & $\mathrm{CC}$ & 15 \\
\hline All Tier 3 & & 93845315 & 115389037 & 89027 & 94109 & 6082 & & 23 \\
\hline
\end{tabular}

Source: 2010 Census, but data for metropolitan areas in Liaoning and Jilin have been estimated on the basis of the growth of prefectural-level cities, as disaggregated data for these provinces were not available. 


\section{ANNEX A2. INVESTMENT IN HOUSING}

\section{Estimation of gross fixed residential capital formation and of the stock of structures}

Casual observation of Chinese cities suggests that the economy is particularly dependent on residential investment as a source of demand. Yet the official national accounts offer little information as to the quantity of this type of investment or of any other type of investment. Indeed they only present data for the contribution of total capital formation, which includes the change in inventories. Once every five years the constant price data is separated into fixed capital formation and the change in inventories.

However, fixed capital formation is central to business cycle developments and to long-term growth. The impact of different types of capital formation on the economy is likely to vary in the short and long term. In particular, housing investment can be subject to major swings. This annex attempts to estimate gross fixed capital in the housing sector and the capital of housing structures for the period 1952 to 2012, as well as the contribution of the housing sector to GDP. The estimates of capital formation are then compared to estimates of the housing stock derived from data on floor area of completed housing.

The estimates of capital formation have been made using mainly official data sources and the methodology of the National Bureau of Statistics (NBS) to transform available data on residential investment into gross fixed capital formation (details below).

\section{The development of residential investment}

Fixed capital formation in housing has risen considerably since the introduction of a market for residential investment in the late 1990s (Figure A2.1). In the immediate aftermath of liberalisation, investment was quite steady as a share of GDP. Starting in 2005, though, the investment started to surge, especially after the opening of the residential mortgage market and the easing of monetary policy in 2009. Between 2009 and 2011, residential fixed capital formation averaged nearly 14\% of GDP. Such a high level of investment has only been sustained in one OECD country (Chile). In other OECD countries, residential investment of over $10 \%$ of GDP has been a symptom of over-building and has been followed by abrupt declines in investment. Even during Japan and Korea's economic take-offs, the maximum share of housing investment in GDP in any four-year period was under $8 \%$.

Figure A2.1. Residential gross fixed capital formation: China and OECD countries $\%$ of GDP

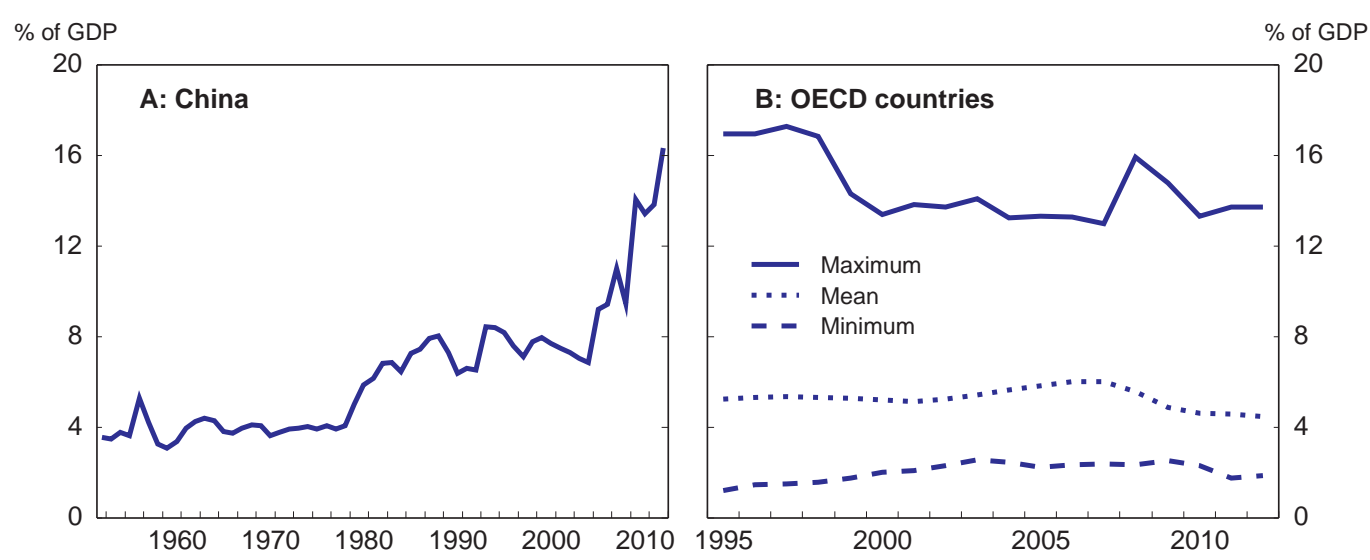

Source: China: author estimates; OECD countries: Economic Outlook 93 database. 
In 2012, residential fixed capital formation appears to have risen even further, despite slackening sales. This reflected an increase in inventories (Figure A2.2) and in the work in progress of property developers (in China, the residential fixed capital formation is assumed to occur once the property developer makes an investment rather than when the building is transferred to a purchaser).

Figure A2.2. Inventory of residential housing and the stock of housing

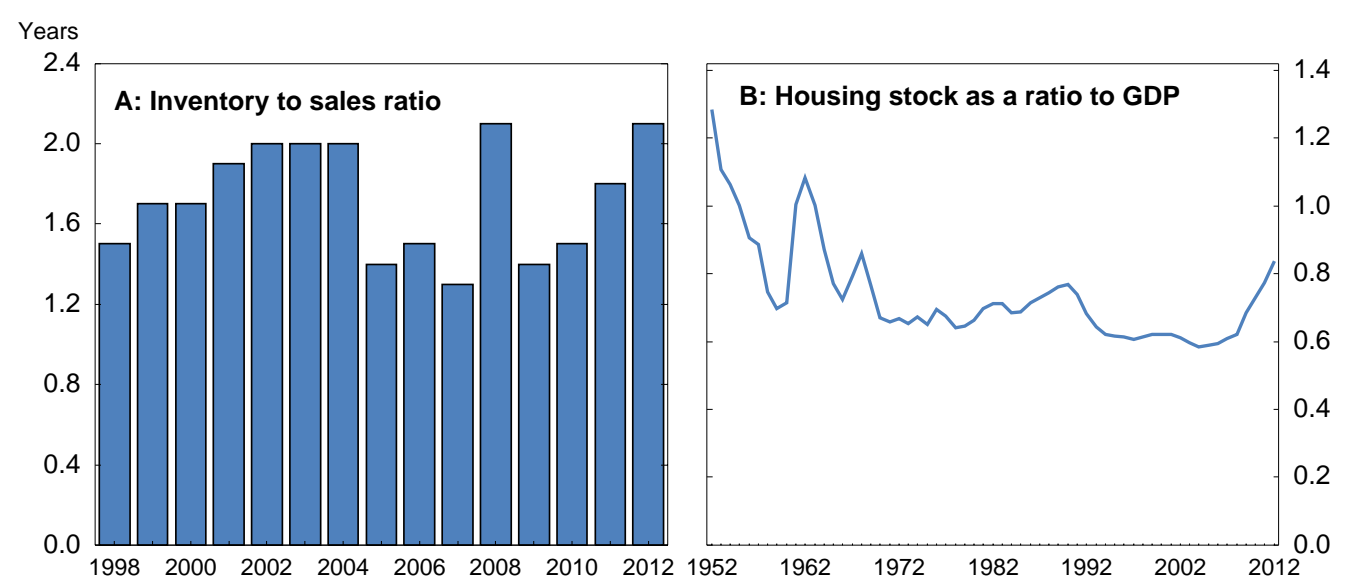

Source: See text.

\section{Development of the residential capital stock}

Cumulating the net residential capital formation data allows to estimate the capital stock of residential structures, starting from information on the initial capital stock in 1952. Errors in the estimation of the initial capital stock do not have a major impact on the current level of the residential capital stock given the enormous expansion of the Chinese economy over the past 60 years.

The housing sector was not a priority under the central planning regime and the residential capital stock fell quite markedly relative to GDP between the nationalisation of housing and the start of openingup and reform in 1978. There was a burst of investment in the second half of the 1980s. The level of the capital stock did not start to rise relative to GDP until around 2003 and has been constantly rising since then. However, the share of the capital stock remains below the levels observed in the 1950s.

\section{Alternative estimates of the housing stock}

Another way to measure the housing stock is to use three sets of data for the area of housing in the country. Data on per capita gross floor area (construction space) can be derived from household surveys. These surveys show the average space occupied by urban and rural households was 32 and $34 \mathrm{~m}^{2}$ per person (Table A2.15). Once allowance is made for the migrant population, which is not counted in the surveys, the average space per person falls to just under $30 \mathrm{~m}^{2}$ per person. This method puts the total floor space occupied by households at 39 billion $\mathrm{m}^{2}$ in 2010 (Table A2.16). In broad terms, this figure is confirmed by the $6^{\text {th }}$ Census which puts the total area occupied by households as being 41 billion $\mathrm{m}^{2}$. A second method is to add the area of housing completed each year to an initial stock based on the household survey. Information on the stock of housing that is completed each year can be cumulated to give the current area of the housing stock. An allowance has to be made for the demolition of the existing stock. For the period 1978 to 1994 the series derived from the household survey and the completions data differ markedly. After 1994, the two series can be reconciled by assuming a demolition rate of $1.2 \%$ per year. In addition, while the series with a demolition rate of $1.2 \%$ agrees with the household survey, there are 
significant year-to-year differences, with the standard deviation of the difference being 1.2 percentage points (Figure A2.3). By 2011, such a demolition rate would be equivalent to the loss of 500 million $\mathrm{m}^{2}$ per year. According to the waste-recycling committee of the State-Owned Assets Supervision and Administration Commission, the actual annual loss of housing area was 600 million $\mathrm{m}^{2}$ per year (SASAC, 2011). The difference between the rate needed to balance the completion data and the household survey data is thus only $0.2 \%$ per year. This figure is, however, difficult to reconcile with the rate of capital consumption the NBS uses for dwellings.

Figure A2.3. Three measures of the housing stock
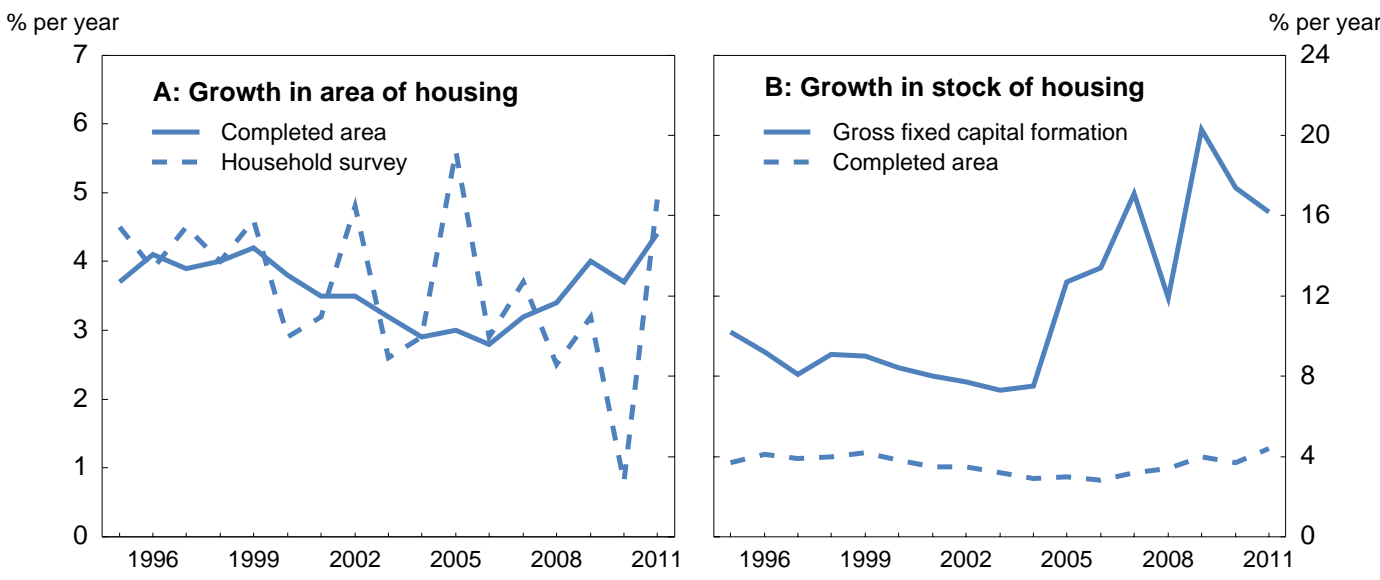

Source: See text.

A set of anomalies emerge when the capital formation data is compared to the area data from the household survey. The first is that while the investment data suggest that nearly $90 \%$ of investment takes place in urban areas, the data for the completed area of housing units suggest that less than half of the area of completed housing is in urban areas. For these two observations to be consistent, the cost of new construction in urban areas would have to be nearly 10 times that in rural areas. While construction costs undoubtedly differ, a tenfold difference seems unlikely. An alternative explanation would be that the two series use different definitions for urban and rural areas. In particular, any collectively owned land is defined as rural, even if it should be classified as urban on the basis of population density. Given these anomalies it is better to compare the investment and area data at a national level.

The capital stock data based on investment show a much more rapid growth than the data based on the completed area of housing (Figure A2.3, Panel B). To some extent, this likely reflects that a given area of housing has become more capital intensive. Construction methods have changed markedly over time: housing units now predominately take the form of multi-story residential towers, whereas four decades ago structures were lower and more basic in style. The quality of housing has also improved markedly (Table A2.1). 
Table A2.1. Housing construction and amenities

\begin{tabular}{|c|c|c|c|c|c|c|c|c|c|}
\hline \multicolumn{10}{|c|}{ Per cent of all households } \\
\hline & & $\begin{array}{l}\text { One floor } \\
\text { only }\end{array}$ & $\begin{array}{l}\text { Own } \\
\text { kitchen }\end{array}$ & $\begin{array}{l}\text { Own } \\
\text { toilet }\end{array}$ & $\begin{array}{c}\text { Average of } \\
\text { four } \\
\text { facilities }\end{array}$ & $\begin{array}{c}\text { Own } \\
\text { toilet } \\
\text { (flushing) }\end{array}$ & $\begin{array}{l}\text { Piped } \\
\text { water }\end{array}$ & $\begin{array}{c}\text { Heated } \\
\text { water }\end{array}$ & $\begin{array}{l}\text { Cooking } \\
\text { fuel gas or } \\
\text { electricity }\end{array}$ \\
\hline \multirow[t]{2}{*}{ Total } & 2000 & 63.1 & 82.5 & 67.4 & 26.9 & 18.0 & 45.7 & 16.3 & 27.5 \\
\hline & 2010 & 47.2 & 82.0 & 66.1 & 49.0 & 35.4 & 64.6 & 44.0 & 52.0 \\
\hline \multirow[t]{2}{*}{ City } & 2000 & n.a. & 85.4 & 71.3 & 63.2 & 50.5 & 87.5 & 43.0 & 71.8 \\
\hline & 2010 & 15.0 & 88.7 & 83.0 & 82.6 & 69.3 & 93.2 & 77.5 & 90.3 \\
\hline \multirow[t]{2}{*}{ Town } & 2000 & n.a. & 83.6 & 62.0 & 41.4 & 26.5 & 69.3 & 26.0 & 43.6 \\
\hline & 2010 & 42.0 & 84.4 & 69.3 & 60.4 & 40.4 & 75.9 & 62.3 & 62.7 \\
\hline \multirow[t]{2}{*}{ Rural } & 2000 & n.a. & 81.1 & 67.0 & 9.4 & 3.4 & 24.2 & 3.7 & 6.6 \\
\hline & 2010 & 70.0 & 76.8 & 54.0 & 28.2 & 11.6 & 41.7 & 36.4 & 23.2 \\
\hline
\end{tabular}

Nonetheless, the large difference between the growth of these two series needs more explanation, especially as it has been widening over time, reaching nearly 11 percentage points in 2011, after averaging $7 \%$ in the previous 25 years (Table A2.2). The elasticity of demand for space is quite low but the elasticity for the demand for structures, at slightly above 1 is closer to that found in studies for the demand for housing. Such an elasticity is similar to the income elasticity of demand for housing which was estimated by Chow and Lin (2010) as lying between 0.7 and 1.1. However, a much lower estimate of the income elasticity of demand, at only 0.18 was found by Wang (2011).

Table A2.2. Growth of per capita housing space and various measures of real income

\begin{tabular}{lc|c|c}
\hline & & & \\
& $\begin{array}{c}\text { Housing space } \\
\text { per capita }\end{array}$ & $\begin{array}{c}\text { Residential } \\
\text { structures per } \\
\text { capita }\end{array}$ & $\begin{array}{c}\text { Structures per } \\
\text { square metre of } \\
\text { housing }\end{array}$ \\
\cline { 2 - 4 } Housing space per capita & \multicolumn{2}{c}{ Annual average percentage change, 1986 to 2011 } \\
\cline { 2 - 4 } & 2.9 & 9.2 & 7.1 \\
Elasticity with respect to GDP per capita & 0.33 & 1.03 & n.a. \\
Elasticity with respect to consumption per capita & 0.38 & 1.12 & n.a. \\
GDP per capita & 8.9 & 0.33 & n.a. \\
Private consumption per capita & 7.6 & 0.39 & n.a. \\
\hline
\end{tabular}

\section{Measurement of the output of the housing sector}

In order to estimate the contribution of the housing sector to the measured level of Chinese GDP, a standard measure of GDP should include the gross rent accruing to housing less maintenance expense. Where housing is owner-occupied, a rental income should be imputed to the housing. The Chinese national accounts do not attempt to measure the rent accruing to the owners of housing units, either for actual rented property or owner-occupied property due to the absence of survey information (Xu et al., 2000). In any case, in the early part of the period it is likely that the rental income failed to cover maintenance and depreciation, reflecting the high degree of subsidisation of urban housing. Rather they impute just the extent of capital consumption but only for owner-occupied property. These estimates are not released regularly. In the $1990 \mathrm{~s}$, for owner-occupied housing alone, the average capital consumption was $1.5 \%$ of GDP and $2.4 \%$ of the value of the structures (Table A2.3). 
ECO/WKP(2013)82

Table A2.3. Owner-occupied housing services in GDP

\begin{tabular}{|c|c|c|c|c|c|c|c|c|c|c|c|}
\hline & 1990 & 1991 & 1992 & 1993 & 1994 & 1995 & 1996 & 1997 & 1998 & 1999 & 2000 \\
\hline \multicolumn{12}{|c|}{100 million yuan } \\
\hline GDP & 18320 & 21280 & 25864 & 34501 & 46691 & 58511 & 68330 & 74894 & 79003 & 82673 & 89113 \\
\hline $\begin{array}{l}\text { Owner- } \\
\text { occupied } \\
\text { dwelling } \\
\text { services }\end{array}$ & 205.5 & 320.6 & 374.2 & 540.0 & 634.0 & 755.2 & 978.8 & 1196.0 & 1213.9 & 1640.3 & 1944.6 \\
\hline$\%$ of GDP & 1.1 & 1.5 & 1.5 & 1.6 & 1.4 & 1.3 & 1.4 & 1.6 & 1.5 & 2.0 & 2.2 \\
\hline $\begin{array}{l}\% \text { of housing } \\
\text { stock value }\end{array}$ & 1.7 & 2.4 & 2.2 & 2.3 & 2.2 & 2.3 & 2.6 & 2.8 & 2.6 & 3.2 & 3.4 \\
\hline
\end{tabular}

By 2012 , not only had the proportion of owner-occupied housing risen to $85 \%$ from $43 \%$ in 1995 , but also the rental market had expanded in major cities (Table A2.4). As a result there has been a growing under-counting of the contribution of the housing sector to overall GDP.

Table A2.4. House tenure nationally and by area

In $\%$ of all tenure types

\begin{tabular}{lrrrr}
\hline & Nationwide & Cities & Towns & Rural \\
\cline { 2 - 5 } Rental & 12.4 & 25.8 & 13.6 & 2.7 \\
Public rental & 1.5 & 2.7 & 2.1 & 0.4 \\
Private rental & 10.9 & 23.2 & 11.4 & 2.3 \\
Owner-occupied & 84.9 & 69.7 & 82.9 & 96.1 \\
Self built & 61.0 & 16.3 & 55.4 & 93.9 \\
First owner & 11.8 & 26.1 & 15.0 & 0.6 \\
Second or later owner & 2.8 & 5.0 & 4.1 & 0.8 \\
Subsidised purchase & 2.3 & 5.1 & 2.5 & 0.2 \\
Formerly public sector & 7.0 & 17.2 & 5.8 & 0.5 \\
Other forms of tenure & 2.7 & 4.5 & 3.5 & 1.2 \\
\hline Total & 100.0 & 100.0 & 100.0 & 100.0 \\
\hline Source: Tabulations of the 2010 Census. & & &
\end{tabular}

The absence of any estimates of actual rents or any imputation of user costs to owner-occupied housing is a major drawback to the national accounts. In order to overcome this problem, the NBS have conducted specific housing cost surveys in major cities. On the basis of these estimates they have recently made new experimental measures of Chinese GDP and private consumption (Xu et al., 2012). These estimates make a substantial difference to both the level of private consumption, its share in GDP and the level of GDP. Private consumption rises by nearly one-fifth and its share in GDP by over 5 percentage points (Table A2.5). Under the existing accounting system the capital consumption charge had risen to $2.5 \%$ of GDP by 2010 (Guo et al., 2012), but under the new system the contribution of housing would be over 4 percentage points higher. 
Table A2.5. Experimental estimates of housing expenditure and GDP for 2010

\begin{tabular}{|c|c|c|}
\hline & Official national accounts & Experimental estimates \\
\hline & \multicolumn{2}{|c|}{100 billion yuan } \\
\hline GDP & 39430.8 & 41173.5 \\
\hline Household consumption & 13327.6 & 16016.5 \\
\hline Market rent & 0.0 & 895.3 \\
\hline Capital consumption & 983.4 & 1830.8 \\
\hline \multirow[t]{2}{*}{ Total } & 983.4 & 2726.1 \\
\hline & \multicolumn{2}{|c|}{$\%$ private consumption } \\
\hline Market rent & 0.0 & 5.6 \\
\hline Imputed rent & 0.0 & 11.4 \\
\hline \multirow[t]{2}{*}{ Total rent } & 0.0 & 17.0 \\
\hline & \multicolumn{2}{|c|}{$\%$ of GDP } \\
\hline Market rent & 0.0 & 2.2 \\
\hline Imputed rent & 0.0 & 4.4 \\
\hline \multirow[t]{2}{*}{ Total rent } & 0.0 & 6.6 \\
\hline & \multicolumn{2}{|c|}{$\%$} \\
\hline Share of consumption in GDP & 33.8 & 38.9 \\
\hline Share of housing in GDP & 2.5 & 6.6 \\
\hline Increase in private consumption & & 20.2 \\
\hline Increase in GDP & & 4.4 \\
\hline
\end{tabular}

Source: Xu et al. (2012).

\section{Methodology for residential fixed capital formation}

As well as aggregate data for the value of gross fixed capital formation, information on fixed asset investment sector by sector is available. This concept, not used by OECD statistical offices, is not the same as gross fixed capital formation. Purchases of existing equipment and structures are included as investment as are purchases of land-use rights. In addition, investment by the real estate development industry is calculated at the cost to the property developer. The actual amount paid by the purchaser of an apartment is not shown in the fixed asset investment. This contrasts to the treatment of residential investment in the standard system of national accounts, where capital formation in producing residential real estate is counted as work in progress (inventory). It is only when the finished product is sold to a final buyer that the outlay is classified as residential fixed capital formation. Several adjustments have to be made to the fixed asset investment data to arrive at the concept of capital formation.

To overcome the lack of sectoral capital formation data, a common procedure has been to allocate gross fixed capital formation to different sectors according to the proportions of fixed asset investment by industry (Bai et al., 2006). However, for the past decade, the discrepancy between the official estimates of fixed asset investment and gross fixed capital formation has widened. Moreover, while such an approach may be an acceptable first approximation, it unduly assumes that differences between the two concepts are spread equally between all sectors of the economy.

This annex therefore uses a different approach, replicating the exact published definition of residential fixed capital formation used by the NBS. For the period starting in the mid-1990s, the data needed to make such a calculation can be found in official publications. The task is more difficult for earlier years and becomes extremely difficult for the period prior to 1978. Nonetheless, an effort has been made here to extend data back to 1952 in order to create a series for the stock of residential capital excluding land, following the example of Maddison (2007). 
The methodology of moving from fixed asset investment to capital formation in the residential sector is laid out in three papers by authors from the NBS. The first outlines the broad definitions of different components of demand in the Chinese national accounts (Xu, 2004). The second gives precise equations $(\mathrm{Wu}, 2009)$ while the third gives the methodology for measuring the gross value added of the housing sector and depreciation (Liu, 2009). In broad terms:

Residential gross fixed asset formation $=$ National residential fixed asset investment

+ investment in land improvement

+ the gross profit margin of residential real estate developers

- purchases of land-use rights by residential developers.

Institutional background is necessary to understand this equation. A real estate developer purchases land-use rights (broadly equivalent to long-term leases in common law jurisdictions) with underlying land ready for the addition of residential units. The use-right that is purchased is for land that has been transformed by the addition of network services (roads, water, drainage and utilities) and the demolition of any existing properties. Local authorities carry out this fixed capital formation before auctioning the land use-rights and so this form of investment has to be added to the outlays of developers.

The gross profit margin of developers is not an observed variable, but has to be calculated according to the equation given by $\mathrm{Wu}(2008)$ :

Gross profit margin of residential real estate developers $=$ Actual sales of residential buildings

- (floor space of residential buildings completed) X (cost per unit of floor space completed).

The information needed to compute this variable is available since 1995.

The value added of the housing sector in the Chinese national accounts consists entirely of an estimate of depreciation. No addition is made for actual or imputed rents of owner occupiers nor is any deduction made for maintenance or management charges in apartment buildings. The NBS has assumed different depreciation rates for residences in urban and rural areas. For the former, the rate has always been $2 \%$ per year. In rural areas, the NBS assumed 4\% per year up to 2004 and 3\% per year from 2005 . This methodology resulted in urban housing contributing 2.4\% to national GDP in 2010 (Xu et al., 2012). However, if an imputed user cost is considered as the imputed rent of owner-occupiers and actual rents are used for renters, then the share of housing in GDP is estimated to rise to $6.6 \%$. Adding rental costs to the measurement of private consumption pushes up the consumption share of GDP by over 5 percentage points from 33.8 to $38.9 \%$.

\section{Data sources}

For 1995-2011, data has been taken from the NBS 2012 Yearbook and in a few cases from the China Premium database of CEIC. For 2012, data has been taken from CEIC. For 1980-94, data has been taken from NBS (2002). For earlier years, data for housing provided by the state-owned sector - the principal provider of housing in urban areas in that period - has been taken from NBS (2004). Little official data is available for rural housing investment in 1952-79. Two sources are a book by Kang (1974) and a report by the Rand Corporation (Liu et al., 1963). Even given the estimates in these books, an assumption has had to be made for the level of rural housing investment between 1958 and 1979, a procedure also adopted by Maddison (op. cit.). 
$\mathrm{ECO} / \mathrm{WKP}(2013) 82$

The precise sources used for each variable are presented in Table A2.16.

\section{Results}

\section{Urban investment}

A series for urban residential fixed asset investment has been constructed for 1952-2012 (Table A1.7). Two elements of the series had to be estimated. First, as residential real estate developers only emerged during the 1980s, official sources do not present data for this sector until 1995. However, between 1986 and 1995 information is available on both the value of total real estate development and the area developed both in total and for residential purposes (Table A2.8). Residential investment has been estimated on the assumption that the cost per square metre of residential and non-residential construction is the same. Second, prior to 1980, no data is available for investment in urban areas by collectives or individuals. It has been assumed that over 1952-79 investment moves in line with urban household consumption.

\section{Rural investment}

A series for rural residential fixed asset investment has been developed for 1952-2012 (Table A2.9). Up to 1980 , no official data is available but estimates based on official surveys have been made by Kang (1974). Between 1958 and 1980, investment has been assumed to move in line with rural household consumption.

\section{Gross margin of developers}

A series for the profit margin of residential property developers is presented in Table A2.10. All the data needed to construct the series is available from 1995 from official sources. Prior to that date, no data is available for the sale price of residential property. Between 1987 and 1994, the residential price has been assumed to be equal to the price per square metre of all property sold by real estate developers. Between 1980 and 1987 the margin has been assumed to be zero.

\section{Land purchases}

The value of land purchases by residential property developers has been estimated from data published by the Ministry of Land and is shown in column 6 of Table A2.11. There is, however, some uncertainty about the units in which the land price is expressed. The price is usually stated to be measured in yuan per square metre of land. However, according to Deng et al. (2012), the price is calculated as yuan per square metre of allowed floor space in official data from the Ministry of Land and Natural Resources. However, in the calculations here, land prices have been assumed to be measured on a physical space basis. Consistent published data for residential land prices is only available since 2008, though data on local government auction sales has been gathered since 2003. For the period prior to 2003, land price data is available in the Chinese Statistical Yearbook but covers sales of land for all purposes (Dong, 2010). There is a major difference in the level of the two prices from 2008 to 2012, but nonetheless it has been assumed that the two series can be spliced to form a continuous series. Data for the area of land purchased for residential development is available since 1996. Data for land improvement expenditure is available from 1995 to 2010 . The series has been extended forwards to 2012 by assuming such outlays are a constant portion of GDP and backwards by assuming a constant real expenditure on land improvement per square metre of residential property sold. Obtaining a consistent data series for land prices requires further investigation. 


\section{Stock of residential structures}

With the above series and the relationships between them, the level of residential gross fixed capital formation can be estimated in current prices (Tables A2.11) and 2005 prices (Table A2.12). The information for fixed capital formation can then be transformed into an estimate of the residential capital stock. This requires an estimate of the stock of fixed residential capital in 1952. Construction costs appear to have been of the order of 15 yuan per $\mathrm{m}^{2}$ in rural areas and five times higher in urban areas according to Kang (1974). It is generally accepted that the average per capita living space in urban areas in China was $4.5 \mathrm{~m}^{2}$, equivalent to $10 \mathrm{~m}^{2}$ of construction area. These estimates have been used to create an initial capital stock for residential structures in 1952, assuming that the structures had been depreciated by $50 \%$.

In addition to the initial stock of capital, an estimate of the depreciation rate in subsequent years is required. The NBS assumes a $2 \%$ annual depreciation rate for urban residences. Such depreciation rates seem reasonable for houses that are well maintained, at least in the United States (Harding et al., 2007). In rural areas, it assumes a depreciation rate of 4\% between 1952 and 2004 and then a rate of $3 \%$ (Liu, 2009). However, the analysis here requires an estimate of the depreciation rate of the structures only. This depreciation rate will be higher than the depreciation rate for houses because land does not depreciate. It will be higher in countries where the share of land in the overall price is high, as in China, than in countries where the share of land is low. This is due to the incentive to demolish a building once its overall value is less than the value of the land used for the construction (Nomura and Momose, 2008). Here a depreciation rate of $6 \%$ has been used for urban and rural structures as an alternative to the official assumptions. If land is one-third the cost of a new housing unit, then such a deprecation rate assumes that houses are demolished after a life of 18 years. The official depreciation rate in contrast assumes that buildings are demolished after 55 years. The results of the calculations are shown in Table A2.13.

\section{Estimating residential construction inventory changes}

The definition of capital formation used in China does not correspond to standard international practice. Work undertaken on a building before it is sold is counted as capital formation while in international practice it would be counted as work in progress. Buildings that have been completed, but not sold, would be counted as inventory internationally but are counted as fixed capital formation in China. However using the information laid out above, it is possible to separate inventory and working in progress from the basic fixed asset investment data.

Capital formation should be measured from sales data using selling prices. However fixed asset investment is estimated at building costs. The developers' margin can removed from data measuring sales, so that sales are valued on the same basis as fixed asset investment. At that point, the difference between the flow of sales at cost and fixed asset investment at cost represents the sum of the increase in inventory of completed (but unsold) buildings and work in progress. No official data is available for the stock on inventory and work in progress. However, the level of inventory can be calculated if an assumption is made as to its level in a base year. Here it has been assumed that inventory and work in progress represent 1.5 years of sales in 2000 . Continuous series for changes in inventory and work in progress are shown in Table A2.14. 
ECO/WKP(2013)82

\section{Area of housing}

Survey data

Estimates of the living space per person in rural and urban areas have been published annually since 1978 and for intermittent years prior to 1978. The coverage of the data series has varied considerably over time as has the definition of the series. Three measures of living space have been used at different points in time.

The first one (useable space) excludes bathroom, toilets and storage space.

The second measure (living space) includes the areas which are omitted in the first measure and are referred to as "auxiliary" spaces in statistical publications. In total, these two areas are known as living space.

Finally, there is a measure known as construction space. This measure includes walls and, in the case of apartments, also includes common areas such as corridors, stairwells, lift shafts and a pro-rata share of all other common facilities.

A common rule of thumb is that living space is $75 \%$ of construction space and useable space $75 \%$ of living space.

The earliest data is based on the concept of useable space, no doubt due to the prevalence of housing units without private sanitary arrangements. The Statistical Yearbook has published this data from 1952 to 2000, but with a gap between 1953 and 1977. The Ministry of Construction published data for living space from 1986 to 2001 and for construction space from 1986 to 2006.

Starting in 2002, the NBS has published data for the per capita living area in urban areas drawn from its urban household survey. Prior to 2007 various combinations of these three measures were published in the Statistical Yearbook. Since 2007, only the living space data based on answers to the urban household survey is published in the Statistical Yearbook. The drawback to this latter data source is that while rural migrants live in urban areas, accounting for $37 \%$ of the urban population by 2011 , they are not included in the sample for the urban household survey. Consequently, the estimates of living space per person are biased upwards given the low living area of such migrants.

In order to obtain a long time series for urban housing the series for living space from the Ministry of Construction have been spliced to the survey based data in 2002. Then the useable space series has been spliced to the resulting series in 1986.

For rural areas, the data for living space has always been taken from the NBS rural household survey and so is more comparable over time than the urban data. However, data is only available from 1978.

The final series for living space per capita is shown in Table A2.15. The two series then have to be aggregated to create a national series while taking into account the housing space of rural migrants in urban areas. This has been achieved by using the NBS data for rural and urban residents and then splitting the urban population into local residents and rural migrants. The living space of migrants has been assumed constant at $10 \mathrm{~m}^{2}$ per capita. In the quarter century between 1986 and 2011, the average increase in housing space per person was just $2.9 \%$ annually. Given the population of urban and rural residents and migrants an overall housing stock can be computed (Table A2.16). 


\section{Housing completion data}

Besides household surveys, data on the amount housing built in urban and rural areas is also collected directly from administrative returns by construction companies and individuals. The figures for the area of housing can be calculated from the flow data if there is information on demolition rates and the initial housing area. A number of statements from officials at the Construction Ministry put the service life of housing in China at 20 to 30 years. In order to measure the housing stock a measure of scrapping rather than depreciation is needed, as the area of the house continues to exist until it is scrapped, even though it is providing no economic services.

Nationwide, a committee suggested that 0.6 billion $\mathrm{m}^{2}$ were demolished annually between 2008 and 2010 (SASAC, 2011). This figure, if it is just for urban areas, is extremely high. It would imply that there was little net addition to the urban housing stock between 2000 and 2009. Other isolated information suggests that 160 million $\mathrm{m}^{2}$ was demolished in 2003 (Tong, 2005). This figure suggests a service life of 20 years for urban housing built before privatisation. However, it would be wrong to assume that all housing built in a given year was scrapped 20 years later. More likely, there is a distribution of service lives around the mean. Rather than use a fixed life, it has therefore been assumed that $3.3 \%$ of the existing stock is scrapped each year, so $50 \%$ is scrapped within 20 years and $75 \%$ within 40 years. The empirical backing for this assumption is weak.

Later information has suggested that this estimate of scrapping may be slightly too high. Between 2000 and 2010 the average scrapping rate of all housing built before 1989 was $2.9 \%$ according to a comparison of the 2000 and 2010 census. Moreover, the rate may tend to fall over time as scrapping rates are markedly higher for property built before 1970 (Table A2.6).

Table A2.6.Scrapping rate of housing by date of construction

\begin{tabular}{|c|c|c|c|}
\hline \multirow[t]{3}{*}{$\begin{array}{l}\text { Year of } \\
\text { construction }\end{array}$} & \multicolumn{2}{|c|}{ Gross floor area of housing } & $\begin{array}{c}\text { Annual } \\
\text { demolition } \\
\text { rate }\end{array}$ \\
\hline & \multicolumn{2}{|c|}{ Million $\mathrm{m}^{2}$} & $\%$ per year \\
\hline & 2000 & 10 & $2000-2010$ \\
\hline Before 1949 & 71.8 & 32.3 & -7.7 \\
\hline 1949-1959 & 45.2 & 24.9 & -5.8 \\
\hline 1960-1969 & 98.9 & 67.7 & -3.7 \\
\hline 1970-1979 & 282.3 & 217.8 & -2.6 \\
\hline 1980-1989 & 919.5 & 715.9 & -2.5 \\
\hline Before 1989 & 1417.7 & 1058.5 & -2.9 \\
\hline 1990-1999 & 1286.2 & 1338.3 & 0.4 \\
\hline After 2000 & 0.0 & 1527.6 & n.a. \\
\hline All housing & 2703.8 & 3924.4 & 3.8 \\
\hline
\end{tabular}

Source: NBS, tabulations of the 2000 and 2010 Census (in Chinese).

The results for this calculation of the housing stock are shown in Table A2.17. They imply a stock of 10.4 billion $\mathrm{m}^{2}$ in urban areas and 17.3 billion $\mathrm{m}^{2}$ in rural areas. These estimates are about one quarter lower than the estimates based on the household survey. However since 1985, the difference between the two estimates has been constant with the completions data showing a stock that is $70 \%$ lower than that from the survey data. The growth rates are similar, but survey data is more volatile. 
Table A2.7. Residential fixed asset investment in urban areas

100 million yuan, current prices

\begin{tabular}{|c|c|c|c|c|c|c|c|}
\hline & Total & Total & $\begin{array}{c}\text { State- } \\
\text { owned } \\
\text { enterprises }\end{array}$ & $\begin{array}{l}\text { Real estate } \\
\text { developers }\end{array}$ & Collectives & Individual & $\begin{array}{ll}\text { Collectives individual } & \text { in }\end{array}$ \\
\hline & $\begin{array}{l}\text { Actual and } \\
\text { estimated }\end{array}$ & Actual & Actual & $\begin{array}{l}\text { Actual and } \\
\text { estimated }\end{array}$ & Actual & Actual & Constant share GDP \\
\hline 1952 & 8 & & 4.48 & & & & 3.71 \\
\hline 1953 & 16 & & 11.27 & & & & 4.53 \\
\hline 1954 & 14 & & 9.23 & & & & 4.61 \\
\hline 1955 & 11 & & 6.64 & & & & 4.77 \\
\hline 1956 & 18 & & 13.36 & & & & 5.11 \\
\hline 1957 & 19 & & 13.29 & & & & 5.35 \\
\hline 1958 & 13 & & 8.16 & & & & 5.11 \\
\hline 1959 & 19 & & 13.67 & & & & 5.40 \\
\hline 1960 & 22 & & 15.89 & & & & 5.69 \\
\hline 1961 & 14 & & 7.67 & & & & 5.98 \\
\hline 1962 & 10 & & 4.17 & & & & 5.98 \\
\hline 1963 & 13 & & 7.59 & & & & 5.79 \\
\hline 1964 & 18 & & 11.59 & & & & 6.10 \\
\hline 1965 & 16 & & 9.91 & & & & 6.24 \\
\hline 1966 & 16 & & 9.21 & & & & 6.32 \\
\hline 1967 & 12 & & 5.33 & & & & 6.46 \\
\hline 1968 & 12 & & 5.66 & & & & 6.41 \\
\hline 1969 & 18 & & 11.04 & & & & 6.56 \\
\hline 1970 & 15 & & 8.05 & & & & 6.78 \\
\hline 1971 & 21 & & 14.53 & & & & 6.92 \\
\hline 1972 & 26 & & 18.84 & & & & 7.59 \\
\hline 1973 & 29 & & 20.89 & & & & 7.84 \\
\hline 1974 & 31 & & 22.51 & & & & 8.05 \\
\hline 1975 & 32 & & 23.97 & & & & 8.41 \\
\hline 1976 & 32 & & 22.84 & & & & 8.80 \\
\hline 1977 & 36 & & 26.3 & & & & 9.40 \\
\hline 1978 & 49 & & 39.21 & & & & 9.76 \\
\hline 1979 & 88 & & 77.28 & & & & 10.25 \\
\hline 1980 & 132 & & 120.09 & 0.0 & 3.28 & 8.51 & 11.79 \\
\hline 1981 & 146 & & 129.00 & 0.0 & 6.04 & 11.43 & \\
\hline 1982 & 191 & & 169.91 & 0.0 & 9.22 & 11.78 & \\
\hline 1983 & 185 & & 158.67 & 0.0 & 11.04 & 15.65 & \\
\hline 1984 & 208 & & 158.42 & 10.0 & 12.23 & 27.09 & \\
\hline 1985 & 327 & & 240.43 & 20.0 & 16.71 & 49.39 & \\
\hline 1986 & 364 & & 232.45 & 46.8 & 18.84 & 65.42 & \\
\hline 1987 & 427 & & 246.32 & 69.5 & 21.28 & 89.96 & \\
\hline 1988 & 569 & & 283.16 & 119.2 & 26.23 & 140.11 & \\
\hline 1989 & 526 & & 252.14 & 126.4 & 21.05 & 126.02 & \\
\hline 1990 & 475 & & 229.29 & 117.4 & 17.81 & 110.33 & \\
\hline 1991 & 604 & & 301.89 & 155.9 & 20.97 & 125.09 & \\
\hline 1992 & 970 & & 411.17 & 339.0 & 30.33 & 189.77 & \\
\hline 1993 & 1982 & & 640.05 & 898.3 & 162.98 & 280.42 & \\
\hline 1994 & 2756 & & 943.13 & 1184.2 & 241.25 & 387.00 & \\
\hline 1995 & 3278 & & 973.07 & 1460.0 & 368.12 & 477.03 & \\
\hline 1996 & 3326 & 3326.2 & & 1699.2 & & & \\
\hline 1997 & 3320 & 3319.7 & & 1539.4 & & & \\
\hline 1998 & 4311 & 4310.8 & & 2081.6 & & & \\
\hline 1999 & 5051 & 5050.9 & & 2638.5 & & & \\
\hline 2000 & 5435 & 5435.3 & & 3312.0 & & & \\
\hline 2001 & 6262 & 6261.5 & & 4216.7 & & & \\
\hline 2002 & 7249 & 7248.9 & & 5227.8 & & & \\
\hline 2003 & 8625 & 8624.8 & & 6776.7 & & & \\
\hline 2004 & 11010 & 11010.1 & & 8837.0 & & & \\
\hline 2005 & 12826 & 12825.8 & & 10860.9 & & & \\
\hline 2006 & 16306 & 16305.5 & & 13638.4 & & & \\
\hline 2007 & 21238 & 21238.3 & & 18005.4 & & & \\
\hline 2008 & 26516 & 26516.0 & & 22440.9 & & & \\
\hline 2009 & 30513 & 30512.7 & & 25613.7 & & & \\
\hline 2010 & 39763 & 39763.1 & & 34026.2 & & & \\
\hline 2011 & 51773 & 51773.4 & & 44319.5 & & & \\
\hline 2012 & 58184 & 58183.5 & & 49374.2 & & & \\
\hline
\end{tabular}


Table A2.8. Real estate development in urban areas: 1986 to 1995

100 million yuan

\begin{tabular}{lrc}
\hline & \multicolumn{1}{c}{ Total } & Residential \\
\cline { 2 - 3 } 1986 & Actual & Estimated \\
\cline { 2 - 3 } 1987 & 101.0 & 46.8 \\
1988 & 149.9 & 69.5 \\
1989 & 257.2 & 119.2 \\
1990 & 272.7 & 126.4 \\
1991 & 253.3 & 117.4 \\
1992 & 336.2 & 155.9 \\
1993 & 731.2 & 339.0 \\
1994 & 1937.5 & 898.3 \\
1995 & 2554.1 & 1184.2 \\
\hline Source: See Table A2.18.
\end{tabular}

Source: See Table A2.18. 
Table A2.9. Residential fixed asset investment: rural areas 100 million yuan, current prices

\begin{tabular}{|c|c|c|c|c|c|}
\hline & Total & Total & $\begin{array}{l}\text { Collective and } \\
\text { individual }\end{array}$ & Collective & Individual \\
\hline & Actual and estimated & Actual & Estimated & Actual & Actual \\
\hline 1952 & 15.75 & 15.75 & & & \\
\hline 1953 & 12.87 & 12.87 & & & \\
\hline 1954 & 18.36 & 18.36 & & & \\
\hline 1955 & 21.69 & 21.69 & & & \\
\hline 1956 & 35.82 & 35.82 & & & \\
\hline 1957 & 26.46 & 26.46 & & & \\
\hline 1958 & 29 & & 29 & & \\
\hline 1959 & 25 & & 25 & & \\
\hline 1960 & 28 & & 28 & & \\
\hline 1961 & 35 & & 35 & & \\
\hline 1962 & 39 & & 39 & & \\
\hline 1963 & 41 & & 41 & & \\
\hline 1964 & 45 & & 45 & & \\
\hline 1965 & 49 & & 49 & & \\
\hline 1966 & 54 & & 54 & & \\
\hline 1967 & 58 & & 58 & & \\
\hline 1968 & 59 & & 59 & & \\
\hline 1969 & & & 62 & & \\
\hline 1970 & 67 & & 67 & & \\
\hline 1971 & 71 & & 71 & & \\
\hline 1972 & 73 & & 73 & & \\
\hline 1973 & 79 & & 79 & & \\
\hline 1974 & 82 & & 82 & & \\
\hline 1975 & 85 & & 85 & & \\
\hline 1976 & 89 & & 89 & & \\
\hline 1977 & 90 & & 90 & & \\
\hline 1978 & 98 & & 98 & & \\
\hline 1979 & 116 & & 116 & & \\
\hline 1980 & 134 & & 134 & & \\
\hline 1981 & 154.58 & & & 148.81 & 5.77 \\
\hline 1982 & 171.37 & & & 162.00 & 9.37 \\
\hline 1983 & 222.35 & & & 214.54 & 7.81 \\
\hline 1984 & 257.42 & & & 239.38 & 18.04 \\
\hline 1985 & 326.82 & & & 313.15 & 13.67 \\
\hline 1986 & 402.24 & & & 388.56 & 13.68 \\
\hline 1987 & 503.85 & & & 487.21 & 16.64 \\
\hline 1988 & 608.35 & & & 580.97 & 27.38 \\
\hline 1989 & 663.28 & & & 641.68 & 21.6 \\
\hline 1990 & 666.15 & & & 649.78 & 16.37 \\
\hline 1991 & 776.59 & & & 759.25 & 17.34 \\
\hline 1992 & 703.38 & & & 678.53 & 24.85 \\
\hline 1993 & 821.66 & & & 760.26 & 61.4 \\
\hline 1994 & 1102.14 & & & 1002.73 & 99.41 \\
\hline 1995 & 1458.51 & 1458.5 & & 1349.85 & 108.66 \\
\hline 1996 & 1872.3 & 1872.3 & & & \\
\hline 1997 & 2051.0 & 2051.0 & & & \\
\hline 1998 & 2083.0 & 2083.0 & & & \\
\hline 1999 & 2007.9 & 2007.9 & & & \\
\hline 2000 & 2158.9 & 2158.9 & & & \\
\hline 2001 & 2077.6 & 2077.6 & & & \\
\hline 2002 & 2158.2 & 2158.2 & & & \\
\hline 2003 & 2167.5 & 2167.5 & & & \\
\hline 2004 & 2454.0 & 2454.0 & & & \\
\hline 2005 & 2601.5 & 2601.5 & & & \\
\hline 2006 & 3027.5 & 3027.5 & & & \\
\hline 2007 & 3766.7 & 3766.7 & & & \\
\hline 2008 & 4365.2 & 4365.2 & & & \\
\hline 2009 & 5915.5 & 5915.5 & & & \\
\hline 2010 & 5263.9 & 5263.9 & & & \\
\hline 2011 & 6051.1 & 6051.1 & & & \\
\hline
\end{tabular}


ECO/WKP(2013)82

Table A2.10. Operating margin of real estate developers and land purchases

\begin{tabular}{|c|c|c|c|c|c|c|c|c|}
\hline & $\begin{array}{l}\text { Sale } \\
\text { price }\end{array}$ & $\begin{array}{c}\text { Construction } \\
\text { cost }\end{array}$ & Margin & Area sold & $\begin{array}{c}\text { Absolute value } \\
\text { of margin }\end{array}$ & $\begin{array}{c}\text { Quantity of land } \\
\text { purchased }\end{array}$ & Land price & $\begin{array}{c}\text { Land } \\
\text { purchases }\end{array}$ \\
\hline & $\begin{array}{c}\text { Yuan } \\
\text { per } \mathrm{m}^{2}\end{array}$ & Yuan per $\mathrm{m}^{2}$ & $\begin{array}{c}\text { Yuan per } \\
\mathrm{m}^{2}\end{array}$ & $10000 \mathrm{~m}^{2}$ & $\begin{array}{l}100 \text { million } \\
\text { yuan }\end{array}$ & $10000 \mathrm{~m}^{2}$ & $\begin{array}{c}\text { Yuan per } \\
\mathrm{m}^{2}\end{array}$ & $\begin{array}{c}100 \text { million } \\
\text { yuan }\end{array}$ \\
\hline 1987 & 408 & 245 & 163 & 2377 & 39 & & & 49 \\
\hline 1988 & 503 & 302 & 201 & 2549 & 51 & & & 65 \\
\hline 1989 & 573 & 344 & 229 & 2491 & 57 & & & 72 \\
\hline 1990 & 704 & 423 & 282 & 2545 & 72 & & & 90 \\
\hline 1991 & 786 & 471 & 314 & 2745 & 86 & & & 109 \\
\hline 1992 & 995 & 597 & 398 & 3812 & 152 & & & 191 \\
\hline 1993 & 1291 & 775 & 517 & 6035 & 312 & & & 392 \\
\hline 1994 & 1409 & 845 & 563 & 6118 & 345 & & & 434 \\
\hline 1995 & 1509 & 911 & 598 & 6787 & 406 & & & 511 \\
\hline 1996 & 1605 & 1111 & 494 & 6898 & 341 & 7172.3 & & 429 \\
\hline 1997 & 1790 & 1175 & 615 & 7864 & 484 & 6641.7 & & 609 \\
\hline 1998 & 1854 & 1218 & 636 & 10827 & 689 & 10109.3 & 857 & 867 \\
\hline 1999 & 1857 & 1152 & 705 & 12998 & 916 & 11958.9 & 965 & 1154 \\
\hline 2000 & 1948 & 1139 & 809 & 16570 & 1341 & 16905.2 & 1002 & 1694 \\
\hline 2001 & 2017 & 1128 & 889 & 19939 & 1772 & 23409.0 & 1025 & 2398 \\
\hline 2002 & 2092 & 1184 & 908 & 23702 & 2152 & 31356.8 & 1065 & 3338 \\
\hline 2003 & 2197 & 1273 & 924 & 29779 & 2750 & 35696.5 & 1329 & 4745 \\
\hline 2004 & 2608 & 1402 & 1206 & 33820 & 4079 & 48894.6 & 1494 & 7305 \\
\hline 2005 & 2937 & 1451 & 1486 & 49588 & 7367 & 38253.7 & 1753 & 6705 \\
\hline 2006 & 3119 & 1564 & 1556 & 55423 & 8622 & 36573.6 & 2408 & 8807 \\
\hline 2007 & 3645 & 1657 & 1989 & 70136 & 13947 & 40245.8 & 2796 & 11251 \\
\hline 2008 & 3576 & 1795 & 1781 & 59280 & 10558 & 39353.4 & 3517 & 13842 \\
\hline 2009 & 4459 & 2021 & 2438 & 86185 & 21012 & 31909.5 & 3539 & 11293 \\
\hline 2010 & 4725 & 2228 & 2497 & 93377 & 23316 & 39953.1 & 4069 & 16255 \\
\hline 2011 & 4993 & 2373 & 2620 & 96528 & 25295 & 44327.4 & 4457 & 19757 \\
\hline 2012 & 5430 & 2411 & 3019 & 98468 & 29730 & 35666.8 & 4556 & 16248 \\
\hline
\end{tabular}


Table A2.11. Residential gross fixed capital formation

\begin{tabular}{|c|c|c|c|c|c|c|c|c|}
\hline & $\begin{array}{c}\text { Urban } \\
\text { fixed asset } \\
\text { investment }\end{array}$ & $\begin{array}{l}\text { Rural fixed } \\
\text { asset } \\
\text { investment }\end{array}$ & $\begin{array}{l}\text { Nationwide } \\
\text { fixed asset } \\
\text { investment }\end{array}$ & $\begin{array}{l}\text { Plus Margin } \\
\text { real estate } \\
\text { developers }\end{array}$ & $\begin{array}{c}\text { Plus land } \\
\text { improvement } \\
\text { outlays }\end{array}$ & $\begin{array}{l}\text { Less Land } \\
\text { purchases for } \\
\text { residential } \\
\text { development }\end{array}$ & $\begin{array}{l}\text { Equals } \\
\text { Gross fixed } \\
\text { capital } \\
\text { formation }\end{array}$ & \multirow{2}{*}{$\begin{array}{c}\text { GDP } \\
\%\end{array}$} \\
\hline & \multicolumn{7}{|c|}{100 million yuan } & \\
\hline 1952 & 8 & 16 & 24 & & & & 24 & 3.5 \\
\hline 1953 & 16 & 13 & 29 & & & & 29 & 3.5 \\
\hline 1954 & 14 & 18 & 32 & & & & 32 & 3.7 \\
\hline 1955 & 11 & 22 & 33 & & & & 33 & 3.6 \\
\hline 1956 & 18 & 36 & 54 & & & & 54 & 5.3 \\
\hline 1957 & 19 & 26 & 45 & & & & 45 & 4.2 \\
\hline 1958 & 13 & 29 & 43 & & & & 43 & 3.3 \\
\hline 1959 & 19 & 25 & 44 & & & & 44 & 3.1 \\
\hline 1960 & 22 & 28 & 49 & & & & 49 & 3.4 \\
\hline 1961 & 14 & 35 & 48 & & & & 48 & 3.9 \\
\hline 1962 & 10 & 39 & 49 & & & & 49 & 4.2 \\
\hline 1963 & 13 & 41 & 54 & & & & 54 & 4.4 \\
\hline 1964 & 18 & 45 & 63 & & & & 63 & 4.3 \\
\hline 1965 & 16 & 49 & 65 & & & & 65 & 3.8 \\
\hline 1966 & 16 & 54 & 70 & & & & 70 & 3.7 \\
\hline 1967 & 12 & 58 & 70 & & & & 70 & 3.9 \\
\hline 1968 & 12 & 59 & 71 & & & & 71 & 4.1 \\
\hline 1969 & 18 & 62 & 79 & & & & 79 & 4.1 \\
\hline 1970 & 15 & 67 & 82 & & & & 82 & 3.6 \\
\hline 1971 & 21 & 71 & 92 & & & & 92 & 3.8 \\
\hline 1972 & 26 & 73 & 99 & & & & 99 & 3.9 \\
\hline 1973 & 29 & 79 & 108 & & & & 108 & 4.0 \\
\hline 1974 & 31 & 82 & 112 & & & & 112 & 4.0 \\
\hline 1975 & 32 & 85 & 118 & & & & 118 & 3.9 \\
\hline 1976 & 32 & 89 & 120 & & & & 120 & 4.1 \\
\hline 1977 & 36 & 90 & 126 & & & & 126 & 3.9 \\
\hline 1978 & 49 & 98 & 147 & & & & 147 & 4.0 \\
\hline 1979 & 88 & 116 & 204 & & & & 204 & 5.0 \\
\hline 1980 & 132 & 134 & 265 & & & & 265 & 5.8 \\
\hline 1981 & 146 & 155 & 301 & & & & 301 & 6.2 \\
\hline 1982 & 191 & 171 & 362 & & & & 362 & 6.8 \\
\hline 1983 & 185 & 222 & 408 & & & & 408 & 6.8 \\
\hline 1984 & 208 & 257 & 465 & & & & 465 & 6.5 \\
\hline 1985 & 327 & 327 & 653 & & & & 653 & 7.2 \\
\hline 1986 & 364 & 402 & 766 & & & & 766 & 7.5 \\
\hline 1987 & 427 & 504 & 931 & 39 & 43 & 58 & 955 & 7.9 \\
\hline 1988 & 569 & 608 & 1177 & 51 & 53 & 76 & 1205 & 8.0 \\
\hline 1989 & 526 & 663 & 1189 & 57 & 75 & 85 & 1236 & 7.3 \\
\hline 1990 & 475 & 666 & 1141 & 72 & 82 & 107 & 1187 & 6.4 \\
\hline 1991 & 604 & 777 & 1380 & 86 & 96 & 129 & 1435 & 6.6 \\
\hline 1992 & 970 & 703 & 1674 & 152 & 157 & 226 & 1756 & 6.5 \\
\hline 1993 & 1982 & 822 & 2803 & 312 & 325 & 465 & 2976 & 8.4 \\
\hline 1994 & 2756 & 1102 & 3858 & 345 & 364 & 514 & 4053 & 8.4 \\
\hline 1995 & 3278 & 1459 & 4737 & 406 & 423 & 605 & 4960 & 8.2 \\
\hline 1996 & 3326 & 1872 & 5199 & 341 & 369 & 517 & 5391 & 7.6 \\
\hline 1997 & 3320 & 2051 & 5371 & 484 & 395 & 624 & 5626 & 7.1 \\
\hline 1998 & 4311 & 2083 & 6394 & 689 & 338 & 867 & 6553 & 7.8 \\
\hline 1999 & 5051 & 2008 & 7059 & 916 & 319 & 1154 & 7139 & 8.0 \\
\hline 2000 & 5435 & 2159 & 7594 & 1341 & 403 & 1694 & 7643 & 7.7 \\
\hline 2001 & 6262 & 2078 & 8339 & 1772 & 496 & 2398 & 8209 & 7.5 \\
\hline 2002 & 7249 & 2158 & 9407 & 2152 & 559 & 3338 & 8780 & 7.3 \\
\hline 2003 & 8625 & 2167 & 10792 & 2750 & 746 & 4745 & 9544 & 7.0 \\
\hline 2004 & 11010 & 2454 & 13464 & 4079 & 715 & 7305 & 10953 & 6.9 \\
\hline 2005 & 12826 & 2601 & 15427 & 7367 & 941 & 6705 & 17030 & 9.2 \\
\hline 2006 & 16306 & 3028 & 19333 & 8622 & 1219 & 8807 & 20368 & 9.4 \\
\hline 2007 & 21238 & 3767 & 25005 & 13947 & 1501 & 11251 & 29203 & 11.0 \\
\hline 2008 & 26516 & 4365 & 30881 & 10558 & 2122 & 13842 & 29719 & 9.5 \\
\hline 2009 & 30513 & 5915 & 36428 & 21012 & 1680 & 11293 & 47827 & 14.0 \\
\hline 2010 & 39763 & 5264 & 45027 & 23316 & 1729 & 16255 & 53817 & 13.4 \\
\hline 2011 & 51773 & 6051 & 57824 & 25295 & 2037 & 19757 & 65399 & 13.8 \\
\hline 2012 & 58184 & 6898 & 65082 & 29730 & 2237 & 16248 & 80800 & 15.6 \\
\hline
\end{tabular}


Table A2.12. Residential gross fixed capital formation in constant prices

100 million yuan or as specified

\begin{tabular}{|c|c|c|c|c|c|c|c|}
\hline & \multicolumn{3}{|c|}{$\begin{array}{l}\text { Residential gross fixed capital } \\
\text { formation in current prices }\end{array}$} & \multirow{2}{*}{$\begin{array}{c}\text { Price index } \\
\text { construction } \\
\text { and installation }\end{array}$} & \multicolumn{3}{|c|}{$\begin{array}{l}\text { Residential gross fixed capital formation at } \\
2005 \text { prices }\end{array}$} \\
\hline & $\begin{array}{l}\text { Residential } \\
\text { GFCF }\end{array}$ & rural & urban & & $\begin{array}{l}\text { Residential } \\
\text { GFCF }\end{array}$ & rural & urban \\
\hline 1952 & 24 & 16 & 8 & 0.156 & 153.6 & 101.0 & 52.6 \\
\hline 1953 & 29 & 13 & 16 & 0.154 & 186.2 & 83.6 & 102.6 \\
\hline 1954 & 32 & 18 & 14 & 0.153 & 210.4 & 120.0 & 90.4 \\
\hline 1955 & 33 & 22 & 11 & 0.146 & 226.0 & 148.1 & 77.9 \\
\hline 1956 & 54 & 36 & 18 & 0.146 & 371.9 & 245.4 & 126.5 \\
\hline 1957 & 45 & 26 & 19 & 0.140 & 322.5 & 189.2 & 133.3 \\
\hline 1958 & 43 & 41 & 1 & 0.140 & 303.6 & 294.5 & 9.1 \\
\hline 1959 & 44 & 46 & -1 & 0.152 & 290.9 & 299.1 & -8.2 \\
\hline 1960 & 49 & 46 & 3 & 0.152 & 324.4 & 303.6 & 20.8 \\
\hline 1961 & 48 & 39 & 10 & 0.149 & 323.5 & 259.0 & 64.5 \\
\hline 1962 & 49 & 36 & 12 & 0.160 & 305.4 & 227.6 & 77.7 \\
\hline 1963 & 54 & 39 & 15 & 0.168 & 323.5 & 233.2 & 90.3 \\
\hline 1964 & 63 & 46 & 17 & 0.164 & 381.1 & 280.4 & 100.7 \\
\hline 1965 & 65 & 54 & 11 & 0.159 & 410.8 & 342.0 & 68.8 \\
\hline 1966 & 70 & 59 & 11 & 0.156 & 449.4 & 380.5 & 69.0 \\
\hline 1967 & 70 & 56 & 14 & 0.156 & 450.2 & 360.4 & 89.9 \\
\hline 1968 & 71 & 55 & 16 & 0.151 & 468.1 & 362.5 & 105.6 \\
\hline 1969 & 79 & 61 & 18 & 0.147 & 537.9 & 417.2 & 120.7 \\
\hline 1970 & 82 & 71 & 11 & 0.147 & 556.5 & 485.0 & 71.5 \\
\hline 1971 & 92 & 77 & 15 & 0.149 & 617.9 & 516.8 & 101.0 \\
\hline 1972 & 99 & 80 & 19 & 0.151 & 658.3 & 530.4 & 127.9 \\
\hline 1973 & 108 & 86 & 22 & 0.151 & 716.4 & 572.3 & 144.1 \\
\hline 1974 & 112 & 89 & 24 & 0.151 & 743.2 & 586.1 & 157.0 \\
\hline 1975 & 118 & 95 & 23 & 0.153 & 770.6 & 622.6 & 148.0 \\
\hline 1976 & 120 & 94 & 27 & 0.154 & 780.5 & 607.7 & 172.8 \\
\hline 1977 & 126 & 102 & 24 & 0.156 & 806.4 & 651.4 & 155.0 \\
\hline 1978 & 147 & 115 & 32 & 0.157 & 938.0 & 733.1 & 205.0 \\
\hline 1979 & 204 & 128 & 76 & 0.161 & 1270.0 & 799.7 & 470.3 \\
\hline 1980 & 265 & 144 & 122 & 0.165 & 1604.7 & 868.4 & 736.4 \\
\hline 1981 & 301 & 155 & 146 & 0.171 & 1762.8 & 905.1 & 857.6 \\
\hline 1982 & 362 & 171 & 191 & 0.175 & 2073.3 & 980.8 & 1092.6 \\
\hline 1983 & 408 & 222 & 185 & 0.179 & 2277.5 & 1242.1 & 1035.4 \\
\hline 1984 & 465 & 257 & 208 & 0.186 & 2496.5 & 1381.6 & 1114.9 \\
\hline 1985 & 653 & 327 & 327 & 0.200 & 3271.2 & 1636.3 & 1634.9 \\
\hline 1986 & 766 & 402 & 364 & 0.213 & 3602.3 & 1892.2 & 1710.1 \\
\hline 1987 & 955 & 504 & 451 & 0.224 & 4271.6 & 2252.8 & 2018.8 \\
\hline 1988 & 1205 & 608 & 597 & 0.254 & 4744.1 & 2395.4 & 2348.8 \\
\hline 1989 & 1236 & 663 & 572 & 0.367 & 3370.2 & 1809.2 & 1561.0 \\
\hline 1990 & 1187 & 666 & 521 & 0.392 & 3029.7 & 1699.8 & 1330.0 \\
\hline 1991 & 1435 & 777 & 658 & 0.430 & 3336.8 & 1806.4 & 1530.5 \\
\hline 1992 & 1756 & 703 & 1052 & 0.502 & 3496.5 & 1400.7 & 2095.7 \\
\hline 1993 & 2976 & 822 & 2154 & 0.659 & 4513.4 & 1246.2 & 3267.2 \\
\hline 1994 & 4053 & 1102 & 2951 & 0.728 & 5567.7 & 1514.2 & 4053.5 \\
\hline 1995 & 4960 & 1459 & 3502 & 0.762 & 6508.9 & 1913.8 & 4595.1 \\
\hline 1996 & 5391 & 1872 & 3519 & 0.801 & 6731.0 & 2337.6 & 4393.5 \\
\hline 1997 & 5626 & 2051 & 3575 & 0.824 & 6825.5 & 2488.5 & 4337.0 \\
\hline 1998 & 6553 & 2083 & 4470 & 0.828 & 7911.6 & 2514.7 & 5396.9 \\
\hline 1999 & 7139 & 2008 & 5131 & 0.831 & 8592.9 & 2416.8 & 6176.1 \\
\hline 2000 & 7643 & 2159 & 5484 & 0.851 & 8984.1 & 2537.6 & 6446.4 \\
\hline 2001 & 8209 & 2078 & 6131 & 0.863 & 9516.0 & 2408.4 & 7107.6 \\
\hline 2002 & 8780 & 2158 & 6622 & 0.871 & 10077.3 & 2477.0 & 7600.3 \\
\hline 2003 & 9544 & 2167 & 7377 & 0.908 & 10512.7 & 2387.4 & 8125.3 \\
\hline 2004 & 10953 & 2454 & 8499 & 0.982 & 11150.4 & 2498.1 & 8652.2 \\
\hline 2005 & 17030 & 2601 & 14429 & 1.000 & 17030.3 & 2601.5 & 14428.8 \\
\hline 2006 & 20368 & 3028 & 17340 & 1.013 & 20106.2 & 2988.7 & 17117.6 \\
\hline 2007 & 29203 & 3767 & 25436 & 1.065 & 27428.9 & 3537.9 & 23891.0 \\
\hline 2008 & 29719 & 4365 & 25353 & 1.202 & 24724.2 & 3631.6 & 21092.6 \\
\hline 2009 & 47827 & 5915 & 41912 & 1.157 & 41339.7 & 5113.1 & 36226.6 \\
\hline 2010 & 53817 & 5264 & 48554 & 1.214 & 44331.9 & 4336.1 & 39995.8 \\
\hline 2011 & 65399 & 6051 & 59348 & 1.325 & 49351.8 & 4566.3 & 44785.6 \\
\hline 2012 & 80800 & 6801 & 73999 & 1.347 & 60001.6 & 5050.7 & 54950.9 \\
\hline
\end{tabular}


Table A2.13. Capital stock of residential structures

100 million yuan except where specified

\begin{tabular}{|c|c|c|c|c|c|c|}
\hline & \multicolumn{4}{|c|}{ Stock of residential structures at 2005 prices } & \multirow{2}{*}{\multicolumn{2}{|c|}{$\begin{array}{c}\text { Ratio of residential structures to GDP } \\
\text { National }\end{array}$}} \\
\hline & Rural & Urban & & onal & & \\
\hline & $\begin{array}{c}\text { Official } \\
\text { depreciation rate } \\
4 \% \text { per year }\end{array}$ & $\begin{array}{c}\text { Official } \\
\text { depreciation } \\
\text { rate } 2 \% \text { per } \\
\text { year }\end{array}$ & $\begin{array}{c}\text { Mixed } \\
\text { depreciation } \\
\text { rates }\end{array}$ & $\begin{array}{c}\text { Unique } \\
\text { depreciation rate } \\
\text { of } 6 \% \text { per year }\end{array}$ & $\begin{array}{c}\text { Mixed } \\
\text { depreciation rates }\end{array}$ & $\begin{array}{l}\text { Unique } \\
\text { depreciation rate }\end{array}$ \\
\hline 1952 & 2420.0 & 1744.0 & 4164.0 & 4164.0 & 1.28 & 1.28 \\
\hline 1953 & 2406.8 & 1742.0 & 4148.7 & 4100.3 & 1.11 & 1.09 \\
\hline 1954 & 2430.5 & 1727.9 & 4158.3 & 4064.7 & 1.06 & 1.04 \\
\hline 1955 & 2481.4 & 1702.1 & 4183.5 & 4046.8 & 1.00 & 0.97 \\
\hline 1956 & 2627.4 & 1726.5 & 4354.0 & 4175.9 & 0.91 & 0.87 \\
\hline 1957 & 2711.6 & 1756.2 & 4467.8 & 4247.9 & 0.89 & 0.84 \\
\hline 1958 & 2897.6 & 1660.0 & 4557.6 & 4296.6 & 0.74 & 0.70 \\
\hline 1959 & 3080.8 & 1552.1 & 4632.9 & 4329.7 & 0.70 & 0.65 \\
\hline 1960 & 3261.2 & 1479.8 & 4741.0 & 4394.3 & 0.71 & 0.66 \\
\hline 1961 & 3389.8 & 1455.5 & 4845.3 & 4454.2 & 1.00 & 0.92 \\
\hline 1962 & 3481.8 & 1445.9 & 4927.7 & 4492.3 & 1.08 & 0.99 \\
\hline 1963 & 3575.7 & 1449.4 & 5025.1 & 4546.2 & 1.00 & 0.91 \\
\hline 1964 & 3713.0 & 1463.2 & 5176.2 & 4654.5 & 0.87 & 0.78 \\
\hline 1965 & 3906.5 & 1444.3 & 5350.8 & 4786.1 & 0.77 & 0.69 \\
\hline 1966 & 4130.7 & 1426.6 & 5557.3 & 4948.4 & 0.72 & 0.64 \\
\hline 1967 & 4325.8 & 1430.9 & 5756.7 & 5101.7 & 0.79 & 0.70 \\
\hline 1968 & 4515.3 & 1450.6 & 5965.9 & 5263.7 & 0.86 & 0.76 \\
\hline 1969 & 4751.9 & 1484.3 & 6236.2 & 5485.8 & 0.77 & 0.67 \\
\hline 1970 & 5046.9 & 1466.7 & 6513.6 & 5713.2 & 0.67 & 0.59 \\
\hline 1971 & 5361.8 & 1479.7 & 6841.6 & 5988.2 & 0.66 & 0.58 \\
\hline 1972 & 5677.7 & 1518.8 & 7196.6 & 6287.2 & 0.67 & 0.58 \\
\hline 1973 & 6023.0 & 1571.8 & 7594.7 & 6626.4 & 0.65 & 0.57 \\
\hline 1974 & 6368.2 & 1634.5 & 8002.7 & 6971.9 & 0.67 & 0.59 \\
\hline 1975 & 6736.0 & 1684.4 & 8420.4 & 7324.2 & 0.65 & 0.57 \\
\hline 1976 & 7074.3 & 1756.2 & 8830.5 & 7665.3 & 0.69 & 0.60 \\
\hline 1977 & 7442.8 & 1805.8 & 9248.6 & 8011.8 & 0.68 & 0.59 \\
\hline 1978 & 7878.1 & 1902.4 & 9780.5 & 8469.1 & 0.64 & 0.55 \\
\hline 1979 & 8362.7 & 2258.6 & 10621.3 & 9231.0 & 0.65 & 0.56 \\
\hline 1980 & 8896.5 & 2859.5 & 11756.0 & 10281.9 & 0.66 & 0.58 \\
\hline 1981 & 9445.8 & 3545.6 & 12991.3 & 11427.8 & 0.70 & 0.61 \\
\hline 1982 & 10048.7 & 4425.4 & 14474.1 & 12815.4 & 0.71 & 0.63 \\
\hline 1983 & 10888.8 & 5195.3 & 16084.2 & 14324.0 & 0.71 & 0.63 \\
\hline 1994 & 11834.9 & 5998.6 & 17833.4 & 15961.1 & 0.69 & 0.61 \\
\hline 1985 & 12997.8 & 7273.5 & 20271.3 & 18274.6 & 0.69 & 0.62 \\
\hline 1986 & 14370.1 & 8547.2 & 22917.3 & 20780.5 & 0.71 & 0.65 \\
\hline 1987 & 16048.1 & 10053.2 & 26101.3 & 23805.3 & 0.73 & 0.66 \\
\hline 1988 & 17801.6 & 11798.7 & 29600.3 & 27121.1 & 0.74 & 0.68 \\
\hline 1989 & 18898.7 & 12651.8 & 31550.5 & 28864.0 & 0.76 & 0.70 \\
\hline 1990 & 19842.5 & 13222.7 & 33065.2 & 30161.9 & 0.77 & 0.70 \\
\hline 1991 & 20855.2 & 13959.8 & 34815.0 & 31689.1 & 0.74 & 0.67 \\
\hline 1992 & 21421.7 & 15218.0 & 36639.7 & 33284.2 & 0.68 & 0.62 \\
\hline 1993 & 21811.1 & 17572.0 & 39383.1 & 35800.5 & 0.64 & 0.58 \\
\hline 1994 & 22452.8 & 20571.2 & 43024.0 & 39220.1 & 0.62 & 0.57 \\
\hline 1995 & 23468.5 & 23932.1 & 47400.5 & 43375.9 & 0.62 & 0.56 \\
\hline 1996 & 24867.3 & 26889.6 & 51756.9 & 47504.3 & 0.61 & 0.56 \\
\hline 1997 & 26361.1 & 29613.3 & 55974.4 & 51479.6 & 0.61 & 0.56 \\
\hline 1998 & 27821.4 & 33233.3 & 61054.7 & 56302.4 & 0.61 & 0.57 \\
\hline 1999 & 29125.4 & 37415.4 & 66540.8 & 61517.2 & 0.62 & 0.57 \\
\hline 2000 & 30498.0 & 41617.0 & 72114.9 & 66810.2 & 0.62 & 0.58 \\
\hline 2001 & 31686.4 & 46227.6 & 77914.0 & 72317.6 & 0.62 & 0.58 \\
\hline 2002 & 32896.0 & 51054.2 & 83950.2 & 78055.9 & 0.61 & 0.57 \\
\hline 2003 & 33967.6 & 56116.2 & 90083.8 & 83885.2 & 0.60 & 0.56 \\
\hline 2004 & 35446.7 & 61401.5 & 96848.2 & 90002.5 & 0.58 & 0.54 \\
\hline 2005 & 36984.7 & 72146.3 & 109131.0 & 101632.7 & 0.59 & 0.55 \\
\hline 2006 & 38863.9 & 84935.0 & 123798.9 & 115640.9 & 0.59 & 0.55 \\
\hline 2007 & 41235.9 & 103729.9 & 144965.8 & 136131.4 & 0.61 & 0.57 \\
\hline 2008 & 43630.4 & 118598.7 & 162229.1 & 152687.7 & 0.62 & 0.59 \\
\hline 2009 & 47434.6 & 147709.4 & 195144.0 & 184866.1 & 0.68 & 0.65 \\
\hline 2010 & 50347.7 & 178842.6 & 229190.3 & 218106.1 & 0.73 & 0.69 \\
\hline 2011 & 53403.5 & 212897.6 & 266301.1 & 254371.5 & 0.77 & 0.74 \\
\hline 2012 & 56852.1 & 255074.7 & 311926.8 & 299110.8 & 0.84 & 0.81 \\
\hline
\end{tabular}

Source: See Table A2.18. 
Table A2.14. Residential fixed asset investment: reconciliation with sales data

100 million yuan, except where stated

\begin{tabular}{|c|c|c|c|c|c|c|c|c|c|}
\hline & Sales & $\begin{array}{l}\text { Developers } \\
\text { margin }\end{array}$ & $\begin{array}{c}\text { FAl } \\
\text { based } \\
\text { on sales }\end{array}$ & $\mathrm{FAl}$ & $\begin{array}{c}\text { Implied } \\
\text { inventory } \\
\text { change in } \\
\text { FAl }\end{array}$ & $\begin{array}{l}\text { Level of } \\
\text { inventory }\end{array}$ & $\begin{array}{c}\text { Constant } \\
\text { price } \\
\text { inventory } \\
\text { change }\end{array}$ & $\begin{array}{l}\text { Inventory } \\
\text { level } \\
\text { relative to } \\
\text { sales }\end{array}$ & $\begin{array}{l}\text { Contribution } \\
\text { of residentia } \\
\text { inventory to } \\
\text { GDP growth }\end{array}$ \\
\hline & \multicolumn{6}{|c|}{100 million yuan } & $\begin{array}{c}100 \text { million } \\
\text { yuan } 2005 \\
\text { prices }\end{array}$ & Years & $\begin{array}{c}\text { Percentage } \\
\text { points }\end{array}$ \\
\hline 1995 & 1024 & 406 & 618 & 1560.0 & 942 & 520 & 1235.8 & 0.5 & \\
\hline 1996 & 1107 & 341 & 766 & 1699.2 & 933 & 1461 & 1164.9 & 1.3 & -0.1 \\
\hline 1997 & 1408 & 484 & 924 & 1539.4 & 615 & 2395 & 746.8 & 1.7 & -0.5 \\
\hline 1998 & 2007 & 689 & 1318 & 2081.6 & 763 & 3010 & 921.5 & 1.5 & 0.2 \\
\hline 1999 & 2414 & 916 & 1498 & 2638.5 & 1140 & 4150 & 1372.7 & 1.7 & 0.5 \\
\hline 2000 & 3229 & 1341 & 1888 & 3312.0 & 1424 & 5574 & 1673.8 & 1.7 & 0.3 \\
\hline 2001 & 4021 & 1772 & 2249 & 4216.7 & 1968 & 7542 & 2281.1 & 1.9 & 0.5 \\
\hline 2002 & 4958 & 2152 & 2806 & 5227.8 & 2422 & 9964 & 2779.5 & 2.0 & 0.4 \\
\hline 2003 & 6543 & 2750 & 3793 & 6776.7 & 2984 & 12948 & 3286.4 & 2.0 & 0.4 \\
\hline 2004 & 8619 & 4079 & 4541 & 8837.0 & 4296 & 17244 & 4373.6 & 2.0 & 0.7 \\
\hline 2005 & 14564 & 7367 & 7197 & 10860.9 & 3664 & 20908 & 3664.4 & 1.4 & -0.4 \\
\hline 2006 & 17288 & 8622 & 8666 & 13638.4 & 4973 & 25881 & 4909.0 & 1.5 & 0.7 \\
\hline 2007 & 25566 & 13947 & 11618 & 18005.4 & 6387 & 32268 & 5999.0 & 1.3 & 0.5 \\
\hline 2008 & 21196 & 10558 & 10638 & 22440.9 & 11803 & 44071 & 9819.2 & 2.1 & 1.6 \\
\hline 2009 & 38433 & 21012 & 17421 & 25613.7 & 8193 & 52263 & 7081.4 & 1.4 & -1.0 \\
\hline 2010 & 44121 & 23316 & 20805 & 34026.2 & 13222 & 65485 & 10891.3 & 1.5 & 1.3 \\
\hline 2011 & 48198 & 25295 & 22903 & 44319.5 & 21416 & 86901 & 16161.2 & 1.8 & 1.7 \\
\hline 2012 & 53467 & 29730 & 23737 & 49374.2 & 25637 & 112538 & 19037.8 & 2.1 & 0.8 \\
\hline
\end{tabular}


Table A2.15. Different measures of living space per capita

\begin{tabular}{|c|c|c|c|c|c|c|c|}
\hline & \multicolumn{4}{|c|}{ Urban } & \multirow{3}{*}{$\begin{array}{c}\text { Rural } \\
\text { Construction }\end{array}$} & \multirow{2}{*}{\multicolumn{2}{|c|}{$\begin{array}{l}\text { Urban Rural } \\
\text { Construction space } \\
\text { spliced }\end{array}$}} \\
\hline & \multirow[t]{2}{*}{ Usuable } & \multirow[t]{2}{*}{ Living } & \multicolumn{2}{|c|}{ Construction } & & & \\
\hline & & & MoC & NBS & & & \\
\hline 1952 & 4.5 & & & & & 10.0 & 10.1 \\
\hline 1953 & 4.3 & & & & & 9.6 & 9.7 \\
\hline 1954 & 4.2 & & & & & 9.3 & 9.4 \\
\hline 1955 & 4.0 & & & & & 8.9 & 9.0 \\
\hline 1956 & 3.9 & & & & & 8.5 & 8.6 \\
\hline 1957 & 3.7 & & & & & 8.2 & 8.3 \\
\hline 1958 & 3.5 & & & & & 7.8 & 7.9 \\
\hline 1959 & 3.4 & & & & & 7.5 & 7.6 \\
\hline 1960 & 3.2 & & & & & 7.0 & 7.1 \\
\hline 1961 & 3.2 & & & & & 7.0 & 7.1 \\
\hline 1962 & 3.2 & & & & & 7.1 & 7.2 \\
\hline 1963 & 3.2 & & & & & 7.1 & 7.2 \\
\hline 1964 & 3.2 & & & & & 7.2 & 7.3 \\
\hline 1965 & 3.3 & & & & & 7.2 & 7.3 \\
\hline 1966 & 3.3 & & & & & 7.3 & 7.4 \\
\hline 1967 & 3.3 & & & & & 7.3 & 7.4 \\
\hline 1968 & 3.3 & & & & & 7.4 & 7.5 \\
\hline 1969 & 3.4 & & & & & 7.4 & 7.5 \\
\hline 1970 & 3.4 & & & & & 7.5 & 7.6 \\
\hline 1971 & 3.4 & & & & & 7.5 & 7.6 \\
\hline 1972 & 3.4 & & & & & 7.6 & 7.7 \\
\hline 1973 & 3.4 & & & & & 7.6 & 7.7 \\
\hline 1974 & 3.5 & & & & & 7.7 & 7.8 \\
\hline 1975 & 3.5 & & & & & 7.7 & 7.8 \\
\hline 1976 & 3.5 & & & & & 7.8 & 7.9 \\
\hline 1977 & 3.5 & & & & & 7.8 & 7.9 \\
\hline 1978 & 3.60 & & & & 8.1 & 8.0 & 8.1 \\
\hline 1979 & 3.75 & & & & 8.4 & 8.3 & 8.4 \\
\hline 1980 & 3.90 & & & & 9.4 & 8.7 & 9.4 \\
\hline 1981 & 4.15 & & & & 10.2 & 9.2 & 10.2 \\
\hline 1982 & 4.40 & & & & 10.7 & 9.8 & 10.7 \\
\hline 1983 & 4.30 & & & & 11.6 & 9.5 & 11.6 \\
\hline 1984 & 4.90 & & & & 13.6 & 10.9 & 13.6 \\
\hline 1985 & 5.20 & & & & 14.7 & 11.5 & 14.7 \\
\hline 1986 & 6.00 & 8.8 & 12.4 & & 15.3 & 13.3 & 15.3 \\
\hline 1987 & 6.10 & 9.0 & 12.7 & & 16.0 & 13.6 & 16.0 \\
\hline 1988 & 6.30 & 9.3 & 13.0 & & 16.6 & 14.0 & 16.6 \\
\hline 1989 & 6.60 & 9.7 & 13.5 & & 17.2 & 14.5 & 17.2 \\
\hline 1990 & 6.70 & 9.9 & 13.7 & & 17.8 & 14.7 & 17.8 \\
\hline 1991 & 6.90 & 10.3 & 14.2 & & 18.5 & 15.3 & 18.5 \\
\hline 1992 & 7.10 & 10.7 & 14.8 & & 18.9 & 15.9 & 18.9 \\
\hline 1993 & 7.50 & 11.0 & 15.2 & & 20.7 & 16.3 & 19.6 \\
\hline 1994 & 7.80 & 11.4 & 15.7 & & 20.2 & 16.9 & 20.2 \\
\hline 1995 & 8.10 & 11.8 & 16.3 & & 21.0 & 17.5 & 21.0 \\
\hline 1996 & 8.50 & 12.3 & 17.0 & & 21.7 & 18.3 & 21.7 \\
\hline 1997 & 8.80 & 13.0 & 17.8 & & 22.5 & 19.1 & 22.5 \\
\hline 1998 & 9.30 & 13.6 & 18.7 & & 23.3 & 20.1 & 23.3 \\
\hline 1999 & 9.8 & 14.2 & 19.4 & & 24.2 & 20.8 & 24.2 \\
\hline 2000 & 10.3 & 14.9 & 20.3 & & 24.8 & 21.8 & 24.8 \\
\hline 2001 & & 15.5 & 20.8 & & 25.7 & 22.4 & 25.7 \\
\hline 2002 & & & 22.8 & 24.5 & 26.5 & 24.5 & 26.5 \\
\hline 2003 & & & 23.7 & 25.3 & 27.2 & 25.3 & 27.2 \\
\hline 2004 & & & 25.0 & 26.4 & 27.9 & 26.4 & 27.9 \\
\hline 2005 & & & 26.1 & 27.8 & 29.7 & 27.8 & 29.7 \\
\hline 2006 & & & 27.1 & 28.5 & 30.7 & 28.5 & 30.7 \\
\hline 2007 & & & & 30.1 & 31.6 & 30.1 & 31.6 \\
\hline 2008 & & & & 30.6 & 32.4 & 30.6 & 32.4 \\
\hline 2009 & & & & 31.3 & 33.6 & 31.3 & 33.6 \\
\hline 2010 & & & & 31.6 & 34.1 & 31.6 & 34.1 \\
\hline 2011 & & & & 32.7 & 36.2 & 32.7 & 36.2 \\
\hline 2012 & & & & 32.9 & 37.1 & 32.9 & 37.1 \\
\hline
\end{tabular}


Table A2.16. Housing stock estimated from survey data

\begin{tabular}{|c|c|c|c|c|c|c|c|c|}
\hline & \multicolumn{4}{|c|}{ Population } & \multicolumn{4}{|c|}{ Total construction space } \\
\hline & \multirow[t]{2}{*}{ Rural } & \multirow[t]{2}{*}{ Urban } & \multicolumn{2}{|c|}{ Urban } & \multirow[t]{2}{*}{ Rural } & \multirow{2}{*}{$\begin{array}{l}\text { Local } \\
\text { urban }\end{array}$} & \multirow[t]{2}{*}{ Migrants } & \multirow[t]{2}{*}{ Total } \\
\hline & & & Migrants & Residents & & & & \\
\hline & \multicolumn{4}{|c|}{ Millions of people } & \multicolumn{4}{|c|}{ Billion square metres } \\
\hline 1952 & 503.2 & 71.6 & 0.0 & 71.6 & 5.1 & 0.7 & 0.0 & 5.8 \\
\hline 1953 & 509.7 & 78.3 & 0.0 & 78.3 & 5.0 & 0.8 & 0.0 & 5.7 \\
\hline 1954 & 520.2 & 82.5 & 0.0 & 82.5 & 4.9 & 0.8 & 0.0 & 5.6 \\
\hline 1955 & 531.8 & 82.9 & 0.0 & 82.9 & 4.8 & 0.7 & 0.0 & 5.5 \\
\hline 195 & 536.4 & 91.9 & 0.0 & 91.9 & 4.6 & 0.8 & 0.0 & 5.4 \\
\hline 1957 & 547.0 & 99.5 & 0.0 & 99.5 & 4.5 & 0.8 & 0.0 & 5.3 \\
\hline 1958 & 552.7 & 107.2 & 0.0 & 107.2 & 4.4 & 0.8 & 0.0 & 5.2 \\
\hline 1959 & 548.4 & 123.7 & 0.0 & 123.7 & 4.1 & 0.9 & 0.0 & 5.1 \\
\hline 1960 & 531.3 & 130.7 & 0.0 & 130.7 & 3.8 & 0.9 & 0.0 & 4.7 \\
\hline 1961 & 531.5 & 127.1 & 0.0 & 127.1 & 3.8 & 0.9 & 0.0 & 4.7 \\
\hline 1962 & 556.4 & 116.6 & 0.0 & 116.6 & 4.0 & 0.8 & 0.0 & 4.8 \\
\hline 1963 & 575.3 & 116.5 & 0.0 & 116.5 & 4.2 & 0.8 & 0.0 & 5.0 \\
\hline 1964 & 575.5 & 129.5 & 0.0 & 129.5 & 4.2 & 0.9 & 0.0 & 5.1 \\
\hline 1965 & 594.9 & 130.5 & 0.0 & 130.5 & 4.4 & 0.9 & 0.0 & 5.3 \\
\hline 1966 & 612.3 & 133.1 & 0.0 & 133.1 & 4.5 & 1.0 & 0.0 & 5.5 \\
\hline 1967 & 628.2 & 135.5 & 0.0 & 135.5 & 4.7 & 1.0 & 0.0 & 5.7 \\
\hline 1968 & 647.0 & 138.4 & 0.0 & 138.4 & 4.8 & 1.0 & 0.0 & 5.9 \\
\hline 1969 & 665.5 & 141.2 & 0.0 & 141.2 & 5.0 & 1.1 & 0.0 & 6.1 \\
\hline 1970 & 685.7 & 144.2 & 0.0 & 144.2 & 5.2 & 1.1 & 0.0 & 6.3 \\
\hline 1971 & 705.2 & 147.1 & 0.0 & 147.1 & 5.4 & 1.1 & 0.0 & 6.5 \\
\hline 1972 & 722.4 & 149.4 & 0.0 & 149.4 & 5.6 & 1.1 & 0.0 & 6.7 \\
\hline 1973 & 738.7 & 153.5 & 0.0 & 153.5 & 5.7 & 1.2 & 0.0 & 6.9 \\
\hline 1974 & 752.6 & 156.0 & 0.0 & 156.0 & 5.9 & 1.2 & 0.0 & 7.1 \\
\hline 1975 & 763.9 & 160.3 & 0.0 & 160.3 & 6.0 & 1.2 & 0.0 & 7.2 \\
\hline 1976 & 773.8 & 163.4 & 0.0 & 163.4 & 6.1 & 1.3 & 0.0 & 7.4 \\
\hline 1977 & 783.1 & 166.7 & 0.0 & 166.7 & 6.2 & 1.3 & 0.0 & 7.5 \\
\hline 1978 & 790.1 & 172.5 & 0.0 & 172.5 & 6.4 & 1.4 & 0.0 & 7.8 \\
\hline 1979 & 790.5 & 185.0 & 0.0 & 185.0 & 6.6 & 1.5 & 0.0 & 8.2 \\
\hline 1980 & 795.7 & 191.4 & 0.0 & 191.4 & 7.5 & 1.7 & 0.0 & 9.1 \\
\hline 1981 & 799.0 & 201.7 & 13.4 & 188.3 & 8.1 & 1.7 & 0.1 & 10.0 \\
\hline 1982 & 801.7 & 214.8 & 26.8 & 188.0 & 8.6 & 1.8 & 0.3 & 10.7 \\
\hline 1983 & 807.3 & 222.7 & 40.2 & 182.5 & 9.4 & 1.7 & 0.4 & 11.5 \\
\hline 1984 & 803.4 & 240.2 & 53.6 & 186.6 & 10.9 & 2.0 & 0.5 & 13.5 \\
\hline 1985 & 807.6 & 250.9 & 67.1 & 183.8 & 11.9 & 2.1 & 0.7 & 14.7 \\
\hline 1986 & 811.4 & 263.7 & 75.2 & 188.4 & 12.4 & 2.5 & 0.8 & 15.7 \\
\hline 1987 & 816.3 & 276.7 & 81.3 & 195.4 & 13.1 & 2.7 & 0.8 & 16.5 \\
\hline 1988 & 823.7 & 286.6 & 86.1 & 200.5 & 13.7 & 2.8 & 0.9 & 17.3 \\
\hline 1989 & 831.6 & 295.4 & 85.0 & 210.4 & 14.3 & 3.1 & 0.8 & 18.2 \\
\hline 1990 & 841.4 & 302.0 & 86.7 & 215.2 & 15.0 & 3.2 & 0.9 & 19.0 \\
\hline 1991 & 846.2 & 312.0 & 89.1 & 223.0 & 15.7 & 3.4 & 0.9 & 19.9 \\
\hline 1992 & 850.0 & 321.8 & 97.7 & 224.1 & 16.1 & 3.6 & 1.0 & 20.6 \\
\hline 1993 & 853.4 & 331.7 & 110.0 & 221.8 & 16.7 & 3.6 & 1.1 & 21.4 \\
\hline 1994 & 856.8 & 341.7 & 119.6 & 222.1 & 17.3 & 3.7 & 1.2 & 22.3 \\
\hline 1995 & 859.5 & 351.7 & 127.1 & 224.7 & 18.0 & 3.9 & 1.3 & 23.3 \\
\hline 1996 & 850.9 & 373.0 & 130.3 & 242.8 & 18.5 & 4.4 & 1.3 & 24.2 \\
\hline 1997 & 841.8 & 394.5 & 135.3 & 259.2 & 18.9 & 5.0 & 1.4 & 25.3 \\
\hline 1998 & 831.5 & 416.1 & 138.1 & 278.0 & 19.4 & 5.6 & 1.4 & 26.3 \\
\hline 1999 & 820.4 & 437.5 & 139.9 & 297.6 & 19.9 & 6.2 & 1.4 & 27.5 \\
\hline 2000 & 808.4 & 459.1 & 149.7 & 309.4 & 20.0 & 6.7 & 1.5 & 28.3 \\
\hline 2001 & 795.6 & 480.6 & 157.8 & 322.9 & 20.4 & 7.2 & 1.6 & 29.2 \\
\hline 2002 & 782.4 & 502.1 & 165.4 & 336.8 & 20.7 & 8.3 & 1.7 & 30.6 \\
\hline 2003 & 768.5 & 523.8 & 177.1 & 346.7 & 20.9 & 8.8 & 1.8 & 31.4 \\
\hline 2004 & 757.1 & 542.8 & 191.0 & 351.8 & 21.1 & 9.3 & 1.9 & 32.3 \\
\hline 2005 & 745.4 & 562.1 & 204.1 & 358.0 & 22.1 & 10.0 & 2.0 & 34.1 \\
\hline 2006 & 731.6 & 582.9 & 215.6 & 367.3 & 22.5 & 10.5 & 2.2 & 35.1 \\
\hline 2007 & 715.0 & 606.3 & 220.5 & 385.8 & 22.6 & 11.6 & 2.2 & 36.4 \\
\hline 2008 & 704.0 & 624.0 & 225.4 & 398.6 & 22.8 & 12.2 & 2.3 & 37.3 \\
\hline 2009 & 689.4 & 645.1 & 229.8 & 415.3 & 23.2 & 13.0 & 2.3 & 38.5 \\
\hline 2010 & 671.1 & 669.8 & 242.0 & 427.8 & 22.9 & 13.5 & 2.4 & 38.8 \\
\hline 2011 & 656.6 & 690.8 & 251.0 & 439.8 & 23.8 & 14.4 & 2.5 & 40.7 \\
\hline 2012 & 642.22 & 711.82 & 262.6 & 449.2 & 23.8 & 14.8 & 2.6 & 41.2 \\
\hline
\end{tabular}

Source: Table A2.18. 
Table A2.17. Stock of housing estimated from flow of newly completed houses

\begin{tabular}{|c|c|c|c|c|c|c|}
\hline & \multicolumn{3}{|c|}{ Newly completed housing } & \multicolumn{3}{|c|}{ Stock of housing } \\
\hline & Urban & Rural & Total & Urban & Rural & Total \\
\hline & \multicolumn{3}{|c|}{ Million $\mathrm{m}^{2}$} & \multicolumn{3}{|c|}{ Million $\mathrm{m}^{2}$} \\
\hline 1994 & & & & 3700 & 18500 & 22200 \\
\hline 1995 & 375 & 699 & 1074 & 3700 & 18500 & 22200 \\
\hline 1996 & 395 & 828 & 1223 & 4032 & 18983 & 23015 \\
\hline 1997 & 406 & 806 & 1212 & 4380 & 19590 & 23970 \\
\hline 1998 & 476 & 800 & 1276 & 4735 & 20168 & 24903 \\
\hline 1999 & 559 & 834 & 1393 & 5156 & 20733 & 25889 \\
\hline 2000 & 549 & 797 & 1346 & 5655 & 21326 & 26980 \\
\hline 2001 & 575 & 729 & 1304 & 6138 & 21874 & 28012 \\
\hline 2002 & 598 & 742 & 1340 & 6641 & 22348 & 28990 \\
\hline 2003 & 550 & 752 & 1302 & 7162 & 22830 & 29992 \\
\hline 2004 & 569 & 680 & 1249 & 7629 & 23316 & 30945 \\
\hline 2005 & 661 & 667 & 1328 & 8109 & 23725 & 31833 \\
\hline 2006 & 630 & 684 & 1314 & 8676 & 24115 & 32791 \\
\hline 2007 & 688 & 775 & 1463 & 9205 & 24518 & 33723 \\
\hline 2008 & 760 & 834 & 1594 & 9785 & 25007 & 34793 \\
\hline 2009 & 821 & 1021 & 1842 & 10431 & 25550 & 35981 \\
\hline 2010 & 869 & 963 & 1832 & 11131 & 26274 & 37404 \\
\hline 2011 & 1022 & 1127 & 2148 & 11870 & 26931 & 38800 \\
\hline
\end{tabular}


ECO/WKP(2013)82

Table A2.18. Data sources

\begin{tabular}{|c|c|c|c|}
\hline \multicolumn{4}{|c|}{ Urban residential fixed investment } \\
\hline Total & $1995-2011$ & 2012 Statistical Yearbook & Table 5.6 \\
\hline $\begin{array}{l}\text { SOE residential capital } \\
\text { construction }\end{array}$ & $1980-2000$ & Statistics of Investment in Fixed Assets, 1950-2000 & p. 108 \\
\hline $\begin{array}{l}\text { SOE residential technical } \\
\text { transformation }\end{array}$ & $1980-2000$ & Statistics of Investment in Fixed Assets, 1950-2000 & p. 258 \\
\hline Individuals, residential & $1981-2000$ & Statistics of Investment in Fixed Assets, $1950-2000$ & p. 482 \\
\hline Individuals, residential & 1981 & Statistics of Investment in Fixed Assets, 1950-2001 & p. 469 \\
\hline Collectives, residential & $1980-2000$ & Statistics of Investment in Fixed Assets, $1950-2000$ & p. 420 \\
\hline $\begin{array}{l}\text { SOE residential capital } \\
\text { construction }\end{array}$ & $1950-1979$ & Statistics of Investment in Fixed Assets, 1950-2000 & p. 108 \\
\hline $\begin{array}{l}\text { Individuals and collectives, } \\
\text { residential }\end{array}$ & $1950-1979$ & Estimated at $3.2 \%$ of GDP based on 1980 data & \\
\hline Collectives, residential & $1950-1979$ & Estimated at $\mathrm{x} \%$ of GDP based on 1980 data & \\
\hline Real estate development & $1996-2011$ & 2012 Statistical Yearbook & Table 5.6 \\
\hline Real estate development & 1986-1995 & Statistics of Investment in Fixed Assets, $1950-2000$ & pp. 369-70 \\
\hline \multicolumn{4}{|c|}{ Margin of residential real estate developers } \\
\hline Cost per square metre & $1995-2011$ & 2012 Statistical Yearbook & Table 5.34 \\
\hline Sale price & $1995-2011$ & 2013 Statistical Yearbook & Table 5.38 \\
\hline Sales volume & $1995-2011$ & 2013 Statistical Yearbook & Table 5.36 \\
\hline Cost per square metre & 1986-1994 & Estimated at $60 \%$ of sale price & \\
\hline Sale price & 1986-1994 & Statistics of Investment in Fixed Assets, 1950-2000 & p. 370 \\
\hline Sales volume & 1986-1994 & Statistics of Investment in Fixed Assets, 1950-2000 & p. 370 \\
\hline \multicolumn{4}{|l|}{ Rural residential fixed investment } \\
\hline Total & $1995-2011$ & 2012 Statistical Yearbook & Table 5.26 \\
\hline Individuals & $1982-2000$ & Statistics of Investment in Fixed Assets, $1950-2000$ & p. 501 \\
\hline Collective & 1980 to 2000 & Statistics of Investment in Fixed Assets, $1950-2000$ & p. 455 \\
\hline Total & 1952 to 1957 & Capital Formation in Mainland China, 1952-65 & p. 105 \\
\hline Total & 1958 to 1979 & Estimated at $2.5 \%$ of GDP & \\
\hline \multicolumn{4}{|l|}{ Urban floor space completed } \\
\hline SOES & 1953 to 2000 & Statistics of Investment in Fixed Assets, 1950-2000 & p. 238 \\
\hline \multicolumn{4}{|l|}{ Land improvement for real estate } \\
\hline & 1995 to 2010 & $\begin{array}{l}\text { Surveys conducted by the Department of Investment } \\
\text { and Construction Statistics of the NBS published by } \\
\text { CEIC }\end{array}$ & CRKACOF \\
\hline & 1987 to 1994 & Backcast & \\
\hline & 2011 to 2012 & $\begin{array}{l}\text { Extrapolated on the basis of outlays and per square } \\
\text { metre and residential land sales }\end{array}$ & \\
\hline \multicolumn{4}{|l|}{ Residential land prices } \\
\hline & 2008 to 2012 & $\begin{array}{l}\text { Residential land prices in } 105 \text { cities, Ministry of Land } \\
\text { via CEIC }\end{array}$ & CRKAMRB \\
\hline & 1998 to 2007 & $\begin{array}{l}\text { Chain linked with NBS land price derived from area } \\
\text { and value }\end{array}$ & Table 5.30 \\
\hline $\begin{array}{l}\text { Floor area newly completed } \\
\text { dwellings }\end{array}$ & 1978 to 2012 & China Statistical Yearbook & Table 10.35 \\
\hline
\end{tabular}




\section{ANNEX A2. BIBLIOGRAPHY}

Bai, C., C. Hsieh and Y. Qian (2006), "The Return to Capital in China", Brookings Papers on Economic Activity, No. 2.

Deng Y., J. Gyourko and J. Wu (2012). "Land and House Price Measurement In China", IRES Working Paper Series, IRES2012-024, National University of Singapore.

Dong, L. (2010), “An Overview of China's Real Estate Price Index”, National Bureau of Statistics of China presentation to a Joint UNECE/ILO Meeting on Consumer Price Indices, 10-12 May, Geneva.

Guo, W., D. Wang, Y. Zheng, X. Zheng and H. Zhang (2012), "Selection of Accounting Method for the Leasing of Residential Housing", China Opening Journal, No. 2, April, China Development Institute, Shenzhen (in Chinese).

Harding, J., S. Rosenthal and C.F. Sirmans (2007), "Depreciation of Housing Capital, Maintenance, and House Price Inflation: Estimates from a Repeat Sales Model”, Journal of Urban Economics, Vol. 61.

Kang, C. (1974), Capital Formation in Mainland China, 1952-1965, University of California Press, Berkeley.

Liu, D., K. C. Yeh and C. Twanmo (1963), "National Income and Economic Development, 1933-1959, Volume I", Research Memoranda, RM-3519, RAND Corporation.

Liu, N. (2009), "Estimation of Owner Occupied Dwelling Service", presentation to the 12th OECD-NBS Workshop on National Accounts, Paris.

Maddison, A. (2007), Chinese Economic Performance in the Long Run: Second Edition, Revised and Updated 960-2030 AD, OECD Publishing, Paris.

NBS (2002), Statistics on Investment in Fixed Assets of China (1950 - 2000), China Statistical Press

Nomura, K. and F. Momose (2008), "Measurement of Depreciation Rates Based on Disposal Asset Data in Japan", National Wealth Division, Economic and Social Research Institute, Cabinet Office, Government of Japan.

State-Owned Assets Supervision and Administration Commission of the State Council (2011), "Proposal to Set Up a Working Committee on the Recycling of Construction Waste", Press Release, www.sasac.gov.cn/n1180/n1566/n259760/n1902523/n1904676/13344619.html.

Tong, Y. (2005), "Extending Residence Service Life with the Method of the Market Economy", China Real Estate, pp. 36-39 (in Chinese).

Wang, S.-Y. (2011), "State Misallocation and Housing Prices: Theory and Evidence from China", American Economic Review, Vol. 101.

Wu, Y. (2009), “Accounting Methods of China's Annual Expenditure-Based GDP”, Presentation to the 13th OECD-NBS Workshop on National Accounts, December.

Xu, X. (2004), “China’s Gross Domestic Product Estimation”, China Economic Review, 15, pp. 302-322.

Xu, X., Y. Ye and D. Blades (2000), National Accounts for China: Sources and Methods, OECD Publishing.

Xu, X. et al. (2012), "On Residents House Rents and Their Impact on the Consumption Rate", China Opening Journal, No. 2, China Development Institute, Shenzhen (in Chinese). 


\section{WORKING PAPERS}

The full series of Economics Department Working Papers can be consulted at www.oecd.org/eco/workingpapers/

1089. Fiscal devaluation - can it help to boost competitiveness?

(October 2013) by Isabell Koske

1088. How to achieve growth- and equity-friendly fiscal consolidation? A proposed methodology for instrument choice with an illustrative application to OECD countries

(October 2013) by Boris Cournède, Antoine Goujard and Álvaro Pina

1087. Improving school-to-work transition in New Zealand

(September 2013) by Alexandra Bibbee

1086. The agri-food situation and policies in Switzerland

(September 2013) by Peter Jarrett and Charlotte Moeser

1085. Japan's challenging debt dynamics

(August 2013) by Yvan Guillemette and Jan Strasky

1084. Transitions in and out of unemployment among young people in the Irish recession

(August 2013) by Elish Kelly, Seamus McGuinness, Philip O'Connell, David Haugh and Alberto González Pandiella

1083. Is there convergence of Russia's regions? Exploring the empirical evidence: 1995-2010

(August 2013) by Hartmut Lehmann and Maria Giulia Silvagni

1082. The benefits and costs of highly expansionary monetary policy

(August 2013) by Łukasz Rawdanowicz, Romain Bouis and Shingo Watanabe

1081. The effectiveness of monetary policy since the onset of the financial crisis

(August 2013) by Romain Bouis, Łukasz Rawdanowicz, Jean-Paul Renne, Shingo Watanabe and Ane Kathrine Christensen

1080. Responding to key well-being challenges in Austria

(August 2013) by Rauf Gönenç, Oliver Röhn, Christian Beer and Andreas Wörgötter

1079. Austria's well-being goes beyond GDP

(August 2013) by Oliver Röhn, Rauf Gönenç, Christian Beer and Romina Boarini

1078. Improving fiscal federal relations for a stronger Mexico

(August 2013) by Aida Caldera Sánchez

1077. Deleveraging: challenges, progress and policies

(August 2013) by Romain Bouis, Ane Kathrine Christensen and Boris Cournède

1076. Policies to support sustainable long-term growth in New Zealand

(July 2013) by Calista Cheung

1075. Do structural policies affect macroeconomic stability? 
(July 2013) by Volker Ziemann

1074. A simple fiscal stress testing model - case studies of Austrian, Czech and German economies (July 2013) by Ondra Kamenik, Zdenek Tuma, David Vavra and Zuzana Smidova

1073. Road connectivity and the border effect: evidence from Europe (July 2013) by Henrik Braconier and Mauro Pisu

1072. Fiscal consolidation across government levels. Part 3: Intergovernmental grants, pro- or counter-cyclical?

(July 2013) by Hansjörg Blöchliger and Balázs Égert

1071. Fiscal consolidation across government levels. Part 2: Fiscal rules for sub-central governments, update of the institutional indicator

(July 2013) by Kaja Fredriksen

1070. Fiscal consolidation across government levels. Part 1: How much, what policies? (July 2013) by Hansjörg Blöchliger

1069. Restructuring the electricity sector and promoting green growth in Japan (June 2013) by Randall S. Jones and Myungkyoo Kim

1068. Labour market policies to promote growth and social cohesion in Korea (June 2013) by Randall S. Jones and Satoshi Urasawa

1067. Education reform in Korea

(June 2013) by Randall S. Jones

1066. Belgium: enhancing the cost efficiency and flexibility of the health sector to adjust to population ageing

(June 2013) by Stéphane Sorbe

1065. Italy and the euro area crisis: securing fiscal sustainability and financial stability (June 2013) by Oliver Denk

1064. Policy implementation in Italy: legislation, public administration and the rule of law (June 2013) by Paul O’Brien

1063. Greening growth in Luxembourg

(June 2013) by Nicola Brandt

Vers une croissance plus verte en Luxembourg

(juin 2013) par Nicola Brandt

1062. The post-crisis narrowing of international imbalances - cyclical or durable? (June 2013) by Patrice Ollivaud and Cyrille Schwellnus

1061. Restructuring welfare spending in Slovenia (June 2013) by Rafał Kierzenkowski

1060. The economics of civil justice: new cross-country data and empirics (August 2013) by G. Palumbo; G. Giupponi; L. Nunziata and J. Mora-Sanguinetti 